\title{
MANAGEMENT IMPACTS ON GHG EMISSIONS AND YIELD FOR AN ORGANIC SOYBEAN CROP
}

\author{
A Thesis \\ Presented to
}

The Faculty of the Graduate School

At the University of Missouri

In Partial Fulfillment

Of the Requirements for the Degree

Masters of Science

\author{
By \\ STEVEN OAKLEY EASTERBY \\ Dr. Newell Kitchen, Thesis Supervisor
}

May 2014 
The undersigned, appointed by the dean of the Graduate School, have examined the Thesis entitled

MANAGEMENT IMPACTS ON GHG EMISSIONS AND YIELD FOR AN ORGANIC SOYBEAN CROP

Presented by Steven Oakley Easterby

A candidate for the degree of

Masters of Science

And hereby certify that, in their opinion, it is worthy of acceptance.

Dr. Newell R. Kitchen

Dr. Robert J. Kremer

Dr. Brent Myers 


\section{ACKNOWLEDGEMENTS}

I owe many people thanks for supporting me with their guidance and encouragement.

First, I would like to thank my advisor Dr. Newell Kitchen for offering me the opportunity to work on this project. I would also like to thank him for the constant advice and guidance he provided me over the past two years. Thank you for your encouragement and unfailing support, you have helped me grow as a student and professional.

I would like to thank Kerry Clark for initiating this project, writing the grant, and overseeing and performing all major operations. Thank you for helping me gain agricultural experience and for fielding my many questions.

I would like to thank Dara Boardman for her hard work, constant support, and patient guidance. She has been crucial to the success of this project. Thank you for educating me on all things country and agriculture.

I would like to thank Timothy Reinbott for helping move this project forward at

all stages and for always supporting us in any way he could. Thank you for accepting me into the world of Bradford Farm and making me feel welcome at the many activities hosted there.

I would like to thank all the undergraduates that helped on my research, Amanda Wolfgeher, Jill Staples, and Hunter. Your time and effort has made this possible.

Fellow graduate students - Bryan Randall, Rebecca Nordenholt, Joseph Dolginow, and Jialiang Guo: Thank you for your help with GHG sampling, especially on hot and humid summer afternoons. 
I would like to thank my committee, Dr. Robert Kremer and Dr. Brent Myers.

Thank you for your knowledge, feedback, and advice. Your support and positive attitude helped me to achieve this goal. 


\section{TABLE OF CONTENTS}

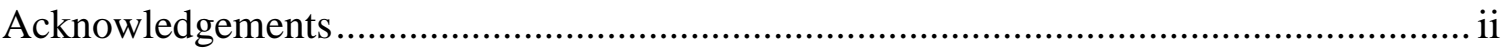

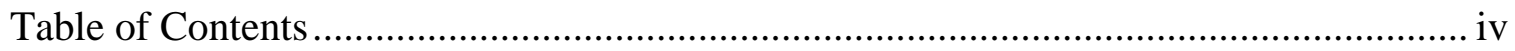

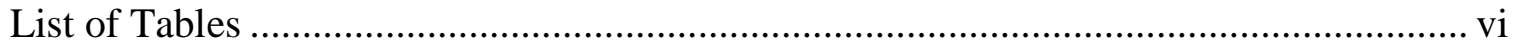

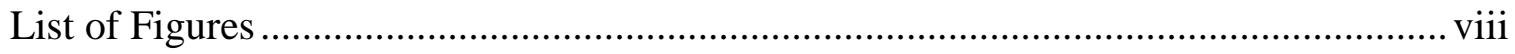

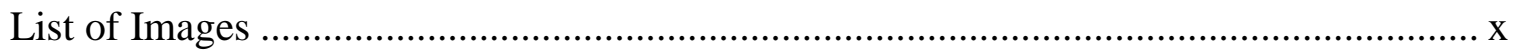

List of Abbreviations ...................................................................................... xi

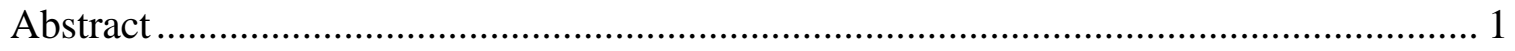

Literature Review ............................................................................................... 3

1.1 Organic Agriculture: A Brief Introduction ................................................ 3

1.1.1 Organic Soybean production ..................................................................... 4

1.1.2 Tillage in organic cropping.............................................................. 7

1.1.3 Cover Crops in Organic Cropping ......................................................... 9

1.1.4 Compost for Organic Crops............................................................ 12

1.2 Greenhouse gases: A Brief Introduction.................................................. 13

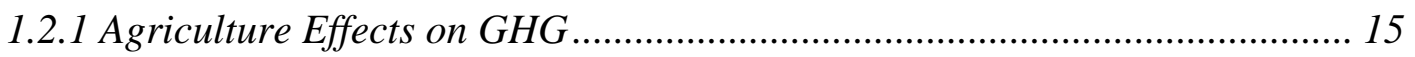

1.2.2 Soil Nitrogen Effects on GHG ....................................................... 17

1.2.3 Soil Organic Matter effects on GHG...................................................... 18

1.2.4 Carbon Sequestration vs Carbon Emissions .............................................. 19

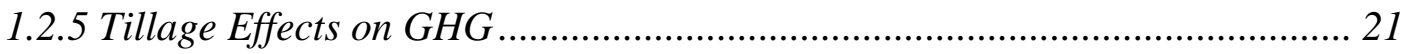

1.2.6 Soil Properties That Promote GHG ...................................................... 24

1.2.7 Soil Moisture Content Effects on GHG ................................................. 25

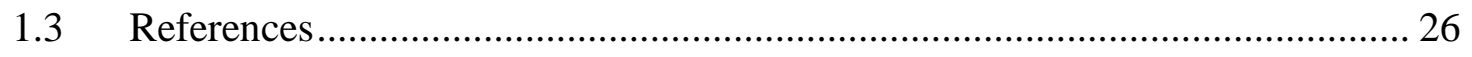

Management Impacts on Greenhouse Gas Emissions for Organic Soybean ................... 34 


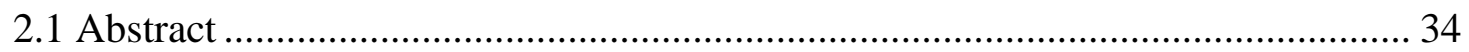

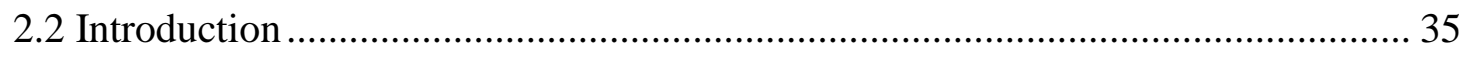

2.3 Materials and Methods …………………………......................................... 40

2.3.1 Research Site and Management .................................................................... 40

2.3.2 Greenhouse Gas Sampling, processing, and Analysis .................................. 43

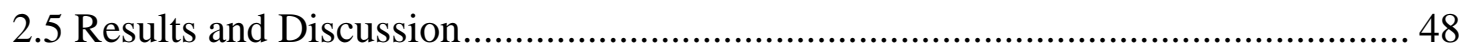

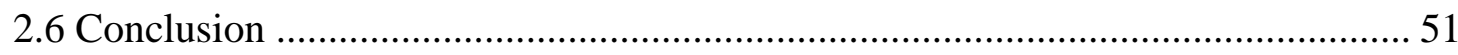

2.7 Tables, Figures, and Images.................................................................................. 53

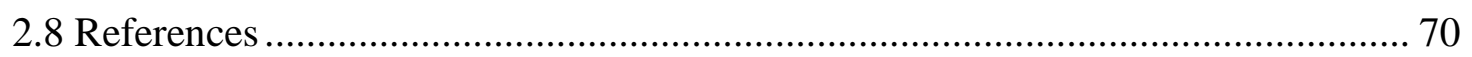

Management Impacts on Organic Soybean Yield ........................................................ 74

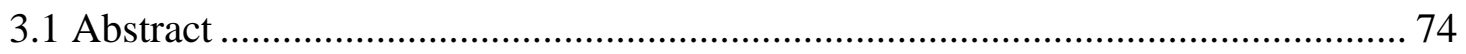

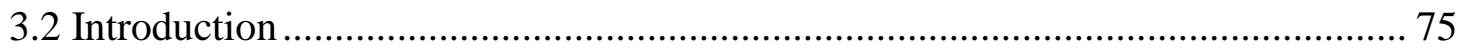

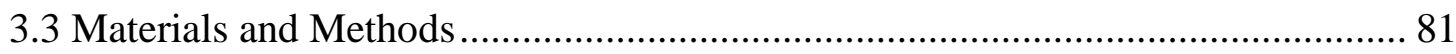

3.3.1 Research Site and management................................................................ 81

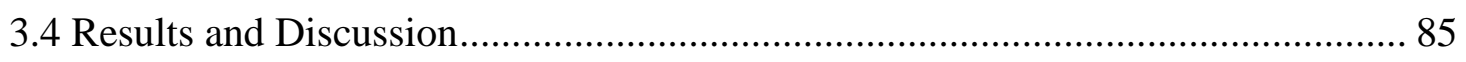

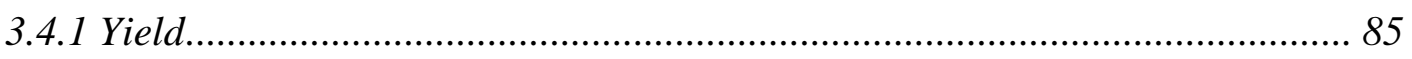

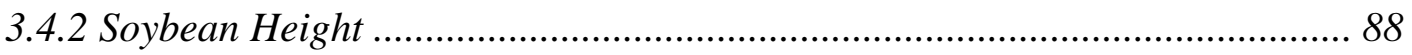

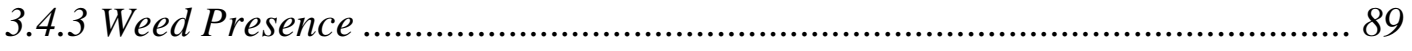

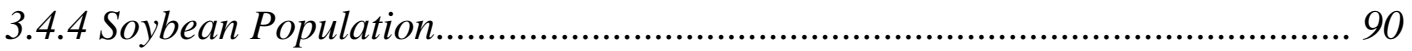

3.4.5 Results: Leaf N, Grain N, and SPAD ....................................................... 91

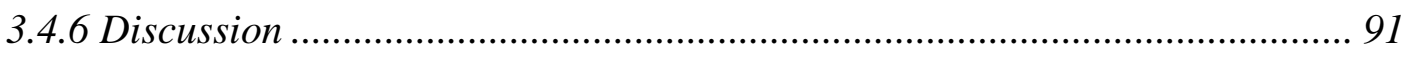

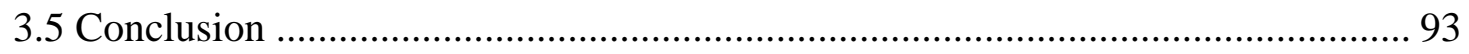

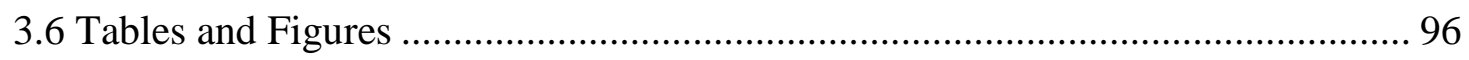

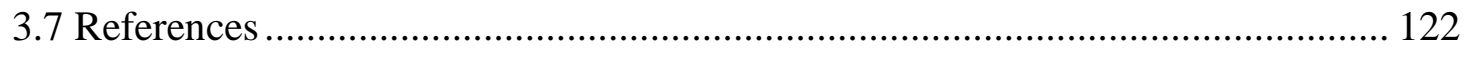

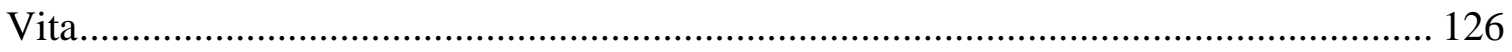




\section{LIST OF TABLES}

Table 2-1. Compost rates during the 2012 and 2013 growing seasons of this study...... 55

Table 2-2. Management techniques and dates utilized during this investigation............ 56

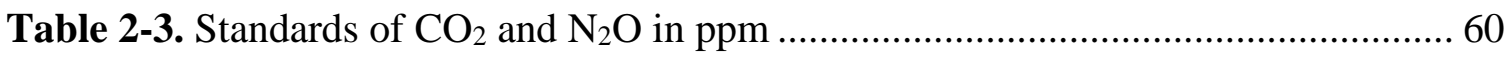

Table 2-4. Results of analysis of variance according to tillage/cover crop practice........ 61

Table 2-5. Results of analysis of variance according to tillage/cover crop practice........ 61

Table 2-6. Effects of tillage/cover crop practice (TCCP) and compost treatments on $\mathrm{CO}_{2}$ and $\mathrm{N}_{2} \mathrm{O}$ emissions of an organic soybean cropping system by year. Results reflect the 2012 and 2013 seasonal fluxes.

Table 2-7. Results of analysis of variance according to tillage/cover crop practice (TCCP) and compost treatments on $\mathrm{N}_{2} \mathrm{O}$ emissions under an organic soybean cropping system. Results reflect the emissions during three sampling dates in 2012 and $2013 \ldots \ldots 67$

Table 2-8. Effects of tillage/cover crop practice (TCCP) and compost treatments ......... 68

Table 2-9. GHG emissions results from other studies. Conventional inputs were used. . 69

Table 3-10. Compost rates during the 2012 and 2013 growing seasons of this study..... 98

Table 3-11. Management techniques and dates utilized during this investigation.......... 99

Table 3-12. Dates for plant response measurements by cropping system. .................. 112

Table 3-13. Analysis of variance results according to tillage/cover crop practice (TCCP) and compost treatments on yield and growth measurements of 2012 organic soybean. 114 Table 3-14. Tillage/cover crop practice (TCCP) and compost treatment means on yield and growth measurements of 2012 organic soybean. 115

Table 3-15. Analysis of variance results according to tillage/cover crop practice 116 
Table 3-16. Tillage/cover crop practice (TCCP) and compost treatment means on yield

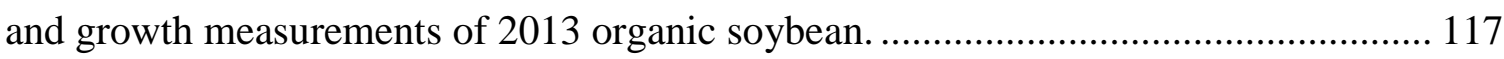




\section{LIST OF FIGURES}

Figure 2-1. Crop rotation followed during this study. .......................................... 53

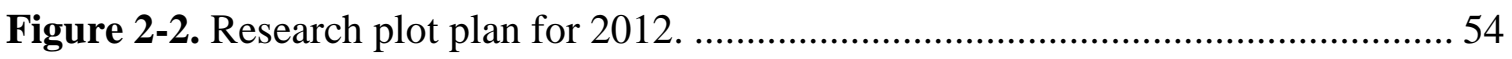

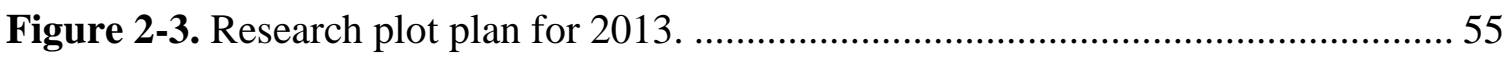

Figure 2-4. Precipitation (cm) for the months of April - October during 2012, 2013, and

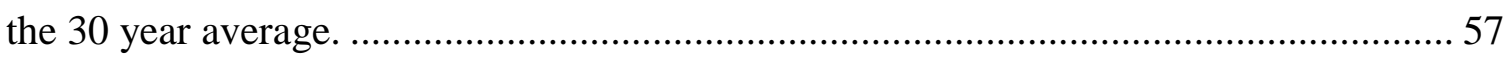

Figure 2-5. Growing degree days (GDD) base $10^{\circ} \mathrm{C}$ for the months of April - October

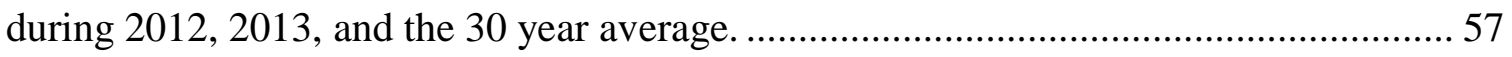

Figure 2-6. $\mathrm{N}_{2} \mathrm{O}$ emissions and daily precipitation or irrigation during the 2012 growing

season.

Figure 2-7. $\mathrm{CO}_{2}$ emissions and daily precipitation during the 2012 growing season...... 64

Figure 2-8. $\mathrm{N}_{2} \mathrm{O}$ emissions and daily precipitation during the 2013 growing season...... 65

Figure 2-9. $\mathrm{CO}_{2}$ emissions and daily precipitation during the 2013 growing season...... 66

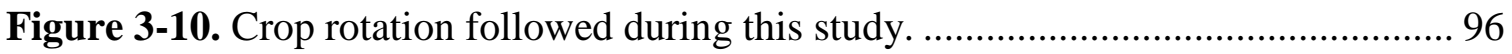

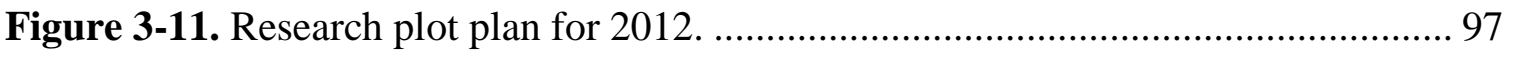

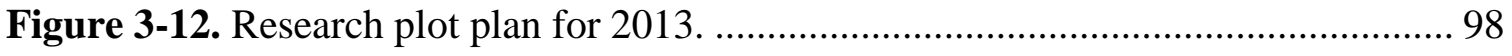

Figure 3-13. Precipitation (cm) for the months of April - October during 2012, 2013, and the 30 year average.

Figure 3-14. Growing degree days (GDD) base $10^{\circ} \mathrm{C}$ for the months of April - October during 2012, 2013, and the 30 year average.

Figure 3-15. Average soybean yield for 2012 according to tillage regime................... 118

Figure 3-16. Average soybean yield for 2013 according to compost rate. Means ........ 118 
Figure 3-17. Average soybean yield for 2013 according to the interaction of

Figure 3-18. Average soybean height for 2012 according to tillage/cover crop practice.

Means calculated by the least squares mean test when analysis of variance was........... 119

Figure 3-19. Average soybean height for 2013 according to the interaction of ........... 120

Figure 3-20. Average weed presence as a percentage of total plot area in 2013 .......... 120

Figure 3-21. Average soybean population at the end of the 2013 growing season ....... 121 


\section{LIST OF IMAGES}

Image 2-1. Chamber used to collect GHG emissions, viewed from the outside............. 58

Image 2-2. Chamber used to collect GHG emissions, viewed from the inside............... 58

Image 2-3. Installing anchors into a Till plot in May 2012 ....................................... 59

Image 2-4. Installing anchors into a NTCC plot in May 2012 ...................................... 59 


\section{LIST OF ABBREVIATIONS}

Ammonium $\left(\mathrm{NH}_{4}^{+}\right)$

Carbon $(\mathrm{C})$

Carbon Dioxide $\left(\mathrm{CO}_{2}\right)$

Conventional tillage (CT)

Greenhouse gas (GHG)

Half the recommended compost rate $(0.5 \mathrm{RR})$

Nitrate $\left(\mathrm{NO}_{3}{ }^{-}\right)$

Nitrite $\left(\mathrm{NO}_{2}^{-}\right)$

Nitrogen $(\mathrm{N})$

Nitrous Oxide $\left(\mathrm{N}_{2} \mathrm{O}\right)$

No-till (NT)

No-till with cover crop (NTCC)

One and a half times recommended compost rate (1.5RR)

Oxygen $\left(\mathrm{O}_{2}\right)$

Recommended compost rate (RR)

Soil organic matter (SOM)

Tillage/cover crop practice (TCCP)

Tilled with cover crop (TillCC)

Tilled with no cover crop (Till) 


\section{ABSTRACT}

As demand for organically grown food increases, growing organic soybean can be profitable and also improve soil ecosystem services through sustainable agronomic practices. However, because most chemical inputs are restricted from organic agriculture, producers rely heavily on tillage for weed control, which in turn can be detrimental to soil health. The use of cover crops, which can be employed to suppress weed growth, may provide an alternative to tillage for sustaining yields. Compost can be used as a fertilizer for organic soybean, however the ideal rate is not always known. Agricultural land has been recognized as a significant source of greenhouse gas (GHG) emissions, however GHG release from soils may vary according to crop production strategies utilizing cover crops and compost. The purpose of this investigation was to determine the effects of tillage, cover crop, and compost rate on yield and the soil release of two GHG, $\mathrm{N}_{2} \mathrm{O}$ and $\mathrm{CO}_{2}$, under an organic soybean cropping system grown on a Missouri claypan soil.

A corn (Zea mays)-soybean (Glycine max)-wheat (Triticum aestivum) organic cropping system was initiated in 2012 at the University of Missouri Bradford Research Center near Columbia, MO using a randomized complete block, split-plot design with four replications. Each crop was investigated independently with tillage/cover crop combinations as the main plot treatment and compost rate for the split-plot treatment. Tillage/cover crop treatments included tilled without cover crop (Till), tilled with cover crop (TillCC), and no-till with cover crop (NTCC). Compost rates were based on soil-test phosphorous recommendations from the University of Missouri Soil Testing Laboratory. Compost treatments were 0 , half the recommended rate $(0.5 \mathrm{RR})$, the recommended rate 
(RR), and 1.5 times the recommended rate (1.5RR). Gas samples were collected at least once a week during the 2012 and 2013 growing seasons, and several times in succession after significant events such as rain, irrigation, and cultivation.

Neither tillage/cover practice nor compost was found to affect either $\mathrm{N}_{2} \mathrm{O}$ or $\mathrm{CO}_{2}$ emissions during 2012 or 2013. Low levels of gas flux were observed. Low emissions may be linked to the drought which occurred during 2012, and below average summer precipitation in 2013.

In 2012 organic soybean grown with tillage and without cover crop out-yielded tilled and no-till with cover crop by $0.88 \mathrm{Mg} \mathrm{ha}^{-1}$, while compost rate had no effect on yield. Although tillage did not have an effect on yield for 2013, the RR and 1.5RR compost rates led to the highest yields. Yield response to compost rate varied by tillage/cover crop practice in 2012. For the no-till systems yield generally increased with compost rate. For the tilled management systems (with or without cover crops) yield was lower at the $0.5 \mathrm{RR}$ and RR. No agronomic explanation is available for this finding. Weed presence was $300 \%$ higher in plots with the $0.5 \mathrm{RR}$ than the 0 compost rate. However, the 0 compost rate was associated with the greatest soybean population count in 2013 . These results suggest that tillage, cover crop practice, and compost rate can have an effect on organic soybean yield.

Cover crops can have a negative effect on yield, especially during periods of drought. There is an ideal compost rate, and yield increases attributed to compost may not occur until multiple years of use. Emissions of $\mathrm{CO}_{2}$ and $\mathrm{N}_{2} \mathrm{O}$ were not affected by tillage, cover crop practice, or compost rate during this study. 


\section{LITERATURE REVIEW}

\subsection{OrganiC Agriculture: A Brief INTRODUCTION}

Organic agriculture systems can impact the environment in a different way than conventional agriculture. For example, one study found an organic system to generate greater soil improvements such as increased $\mathrm{N}$ availability compared to conventional notill (NT) production (Teasdale et al., 2007). Another study suggests that crop yield in organic systems may be less affected by weeds than conventional systems (Ryan et al., 2009). This is especially effective when longer rotations are utilized with diverse crops, which can decrease weed seedbank populations and abundance of some weed species (Teasdale et al., 2004). Yet some techniques employed by organic management (e.g., extensive tillage) may not be sustainable in the long-term, especially on sensitive-soil landscapes. Also, more attention is now being given to GHG emissions in agricultural areas and the potential impact they have on climate change. While a number of studies have investigated GHG emissions as they relate to conventional agriculture, little research has been done on the relationship between organic agriculture management practices and GHG emissions. This literature review provides a synthesis of previous research to better understand how tillage, cover crops, and compost, all common components of organically grown cropping systems, impact yield and GHG emissions in organic soybean (Glycine max) production. The breadth of this review includes results from various management strategies, and includes a diverse array of crops, soils, and weather scenarios. Its intent is to present the background of the research behind this 
thesis: an investigation into organic soybean yield and GHG emissions on Missouri claypan soil.

\subsubsection{ORGANIC SOYBEAN PRODUCTION}

The number of acres devoted to organic production is increasing rapidly (Yussefi and Willer, 2007). In 2005 land area devoted to organic crops in the United States was more than 2.5 times higher than in 1995 (McBride and Greene, 2009). In 2011 total acres devoted to certified organic production surpassed 3.6 million acres, with 1.5 million in harvested cropland (USDA, 2011). The value of sales of organic crops for that year was valued at over $\$ 2.2$ billion with annual sales still increasing. It is clear that organic agriculture is growing rapidly as an industry.

In the state of Missouri, organic cropland comprised approximately 18,000 acres in 2011 over 92 farms (USDA, 2011). This is less than $0.01 \%$ of land devoted to organic cropland nationally. With more than 29 million acres of farmland, including hay and pasture land, spread over 106,000 farms in Missouri, there is ample space for growth (USDA, 2011). Although relatively few, some Missouri farmers are showing greater interest in the increased profit margins associated with organic crop production systems (Cavigelli et al., 2008). As this interest is shared by farmers across the nation, there follows a desire for more information on proven organic system management practices. To meet this demand for information, universities and private agriculture companies are intensifying organic agriculture research.

When performed correctly, organic agriculture can ensure a consistent profit while sustaining or even increasing soil health (Bernstein et al., 2011). This may be a 
welcome change from the constant conflict between farmers vying for larger net yields and environmentalists criticizing synthetic pesticide and fertilizer use. Organic cropping systems can address conservation and environmental issues as well as provide farmers with net return values comparable or even higher than those accrued through conventional agriculture (Archer et al., 2007). This includes grain crops such as soybean.

Organic soybean acreage grew in the U.S. from 50,000 acres in 1995 to 122,000 acres in 2005 (McBride and Greene, 2009). More recently, the rate of acreage growth has declined. From 2005 to 2008 only 34,000 acres were added into production (Service, 2012). As of 2011 only 96,000 acres were devoted to organic soybean production (USDA, 2011).

Organically-grown soybean has received special attention in recent years. As a crop used around the world it is the largest source of animal protein feed and the second largest source of vegetable oil directly consumed by humans (USDA-ERS, 2012). As such there has been a steady demand for organic soybean for both human consumption and animal feed (Delate et al., 2012). Organic livestock producers need organic grain crops to meet certified organic meat and dairy standards (Smith et al., 2011).

When compared to conventionally-raised soybean (chisel-till/herbicide programs), yields for organic soybean are generally lower. After compiling and analyzing a meta-data set of over 350 published comparisons of organic vs conventional crop yields, de Ponti et al., 2012 found the average yield gap between the two systems to be larger than 20\%. A study performed in Maryland found a 19\% yield reduction between organic and conventionally raised soybean (Cavigelli et al., 2008). However, while yields may be lower, prices for organic soybean are often much higher than for conventional 
soybean ( $\$ 30.00 / \mathrm{bu}$ for organic compared to $\$ 12.87 / \mathrm{bu}$ for conventional in 2013 )

(Pitcock, 2013). Even though yield may decrease when transitioning from conventional to organic soybean production, net profit may actually increase. To enjoy these potential profits and to help meet the demand for organic soybean, growers need quality research that leads to guidance on management techniques which support high yields and sustain land resources. However, organic production is still a relatively new area in the agriculture industry. For organically-grown crops there are two considerations that dominate management efforts: 1) quality weed control to preserve water, light, and nutrients for the crop (Teasdale et al., 2007b); and 2) adequate nutrient supply for the crop (Walz, 2004). The most difficult of these problems is weed control.

Many producers cite weed management as their most difficult challenge in growing organically (Walz, 2004). Organic fields tend to have greater weed intensity than conventional fields, which is often the principal reason for decreased yields when compared to conventional systems. A study comparing yield between organic and conventional soybean systems over several years found a $17.5 \mathrm{~kg} \mathrm{ha}^{-1}$ reduction in yield for every $1 \%$ increase in weed cover (Cavigelli et al., 2008). This same study also cited weed competition as the principal reason for the $19 \%$ difference in yield between a conventional and organic soybean crop.

In a conventional system, farmers can target the type of weeds afflicting their crops and control them with herbicides. The herbicide may be costly and time and labor are needed, however, herbicide applications are a relatively quick and easy solution to weed problems. It is much more difficult for organic producers to control weeds. Although organic herbicides do exist, their effectiveness is questionable (Smith et al., 
2010). Instead, tillage is the principal method used by organic producers to control weeds (Smith et al., 2010).

\subsubsection{TILLAGE IN ORGANIC CROPPING}

Organic production systems are typically more tillage-intensive than conventional systems. Raising soybean organically requires increased labor and tillage which are two reasons transition to organic soybean production has been limited. A study performed at the Rodale Institute in Kutztown, PA found organic systems to require 35\% more labor (Pimentel et al., 2005). Often two or three rotary hoeings are required following preplant primary tillage in organic systems, as well as two or three cultivation between rows, to keep weeds in check (Place et al., 2009).

Tillage of agricultural soils has been in widespread use for many years. Tilling prior to planting breaks up the soil, which kills emerged weeds and provides an ideal seed bed for planting. Unfortunately, this frequent use of tillage can degrade soil quality properties. For example, tillage can compact the soil beneath the tillage implement, increase bulk density, exacerbate erosion problems, and diminish soil organic matter (SOM) (Lal, 1997). Soil organic matter, and in turn soil C, is lost quickly after the initial tillage of undisturbed soil. Indeed, $40 \%$ or more of the original soil C may be lost after a period of two decades of continuous tillage (Grandy, 2006). The distribution of organic matter in the soil profile can be changed as the soil is mixed and aeration increases $(\mathrm{Li}$, 1992). These negative effects are especially apparent in areas of highly-erodible soil 
types, where producers are concerned about topsoil loss from erosion due to greater tillage intensity (Nelson et al., 2011).

Because of these negative effects on soil, tillage of conventional agricultural land has decreased over the past decade and replaced by reduced or NT management in many areas of the Corn Belt (Archer et al., 2007; Grandy, 2006). Studies on long-term NT systems are showing increased yields and reduced drought stress when compared to conventional tillage (CT) (Teasdale et al., 2007).

Multiple soil benefits have been attributed to the conversion to NT. Soil moisture is often observed to be higher in NT systems (MacKenzie et al., 1997), thus resulting in higher soil water availability under NT. Soil organic carbon (SOC) has been observed to increase in NT systems (Salinas-Garcia et al., 1997; Wood et al., 1991). Berner et al. (2008), found a $7.4 \%$ increase in SOC in the $0-10 \mathrm{~cm}$ soil layer over a period of three years, while there was no increase in CT. Also, after three years microbial biomass was $28 \%$ higher and dehydrogenase activity $27 \%$ higher in NT than in CT (Berner et al., 2008).

In spite of the many soil benefits associated with NT, weed control is still a critical issue. Systems which use conventional inputs are generally reliant on chemical herbicides for weed control, which are not allowed in organic production (AMS, 2014). Organic farmers seem to be left with no other option besides CT, because minimizing the negative effects of weeds is critical to the pursuit of maximizing agricultural production. However cover cropping can be utilized as a form of weed control in organic production systems. 


\subsubsection{COVER Crops IN ORganic CROPPING}

Cover crops have been used by farmers for centuries (Ingels, 1998). They provide a wide variety of significant benefits. Cover crops have been found to repel certain insects, break up the subsoil, prevent wind and water erosion, suppress weeds, enhance nutrient and moisture availability, and provide additional SOM (Clark, 2008). Different cover crops provide unique benefits which may be better suited to one or several crops. Legume cover crops, such as hairy vetch and Australian pea, have the ability to fix $\mathrm{N}$ in the nodules of leguminous roots. This can help meet $\mathrm{N}$ needs for grain crops like corn (Zea mays) and wheat (Triticum aestivum). These crops preserve and enrich the soil while helping to prevent establishment of weed populations. This literature review will focus on the use of cereal rye (Secale cerale), also known as winter rye, as a cover crop. Rye was the cover crop grown prior to the soybean crop during this investigation.

Rye is the best cool-season cereal cover for absorbing unused soil N (Clark, 2008). It can be seeded later in fall than most other cover crops and still provide a substantial amount of organic matter. Also, its extensive root system helps to prevent soil erosion. Rye's quick establishment and tall growth make it a superb weed suppressant, as does its allelopathic capabilities (Clark, 2008). Through allelopathy rye residue can act as a weed suppressant four weeks after it is destroyed (Yenish et al., 1995).

Allelopathy has been a recognized ecological phenomenon for millennia. Around 300 B.C., Theophrastus, who has been called the "father of Botany," observed that weeds which emerged near chickpeas tended to die out. The chickpeas were releasing toxic chemicals into the surrounding environment which inhibited the growth of plants 
susceptible to these toxins. This effect is known as allelopathy, and since Theophrastus's ancient observation hundreds of other plant species have been reported to be allelopathic, including over 240 weed species (Colquhoun, 2006). Many of these allelopathic plants, otherwise referred to as donor plants, have similar effects on plants of different species living nearby. Germination inhibition and stunted seedling growth are among the most common results of allelopathy. This can occur through the release of chemicals from donor plants by leaching, root exudation, volatilization, and residue decomposition (Ferguson and Rathinasabapathi, 2003).

Common cover crops with observed allelopathic effects include rye, fescue (Festuca spp.,) forage radish (Raphanus sativus,) alfalfa (Medicago sativa,) barley (Hordeum vulgare,) and rapeseed (Brassica napus.) (Qasem and Foy, 2001). Rye has been extensively studied in particular because its allelopathic effects are especially potent, especially with other grass species (Przepiorkowski and Gorski, 1994). This suppression of germination is not limited to weeds. Cash crops planted after the destruction of rye in the spring can also be negatively affected. However, because rye's allelopathic effects are mostly toxic to grass species, the effect on non-grass crops such as soybean is limited (Clark, 2008). A clear understanding of allelopathic interactions is needed to prevent the potential damage it can cause crops.

Establishing a cover crop during a period in the year where no cash crop would otherwise be growing can significantly diminish the presence of weeds. Higher total rye biomass tends to correlate with increased weed suppression (Smith et al., 2010). Greater biomass can be achieved by planting earlier, ideally in September or October (Epplin et al., 2000). Biomass values as low as $9,526 \mathrm{~kg} \mathrm{ha}^{-1}$ have been found to provide sufficient 
weed suppression for maintaining soybean yield (Smith et al., 2010). In fact, Teasdale and Mohler (2000) found that mulch levels greater than $9,000 \mathrm{~kg} \mathrm{ha}^{-1}$ reduced weed cover by $90 \%$. Weed pressure decreases at an exponential rate as mulch levels increase.

Before planting of the cash crop in the spring, the rye must be destroyed, either by tillage, crimping, or mowing. Thus weed populations are minimized and soil is protected from erosion and enriched by the organic matter the rye residue provides. The ideal method of destroying cover crops in preparation for the main crop is still being explored, however, many cover crop managers use a flail mower or roller crimper. The flail mower chops the cover crop into mulch, while the roller crimper is used to roll over the cover crop, thus breaking the plant's stalk at its base and creating a thick mat. The roller crimper can be operated at a faster speed which saves on time spent in the field (Smith et al., 2010). Rolled-rye may result in significantly less weed density than flail-mowed rye (Smith et al., 2010).

While the use of rye as a cover crop does offer many advantages, care has to be taken when managing it before planting the cash crop. If killed late in the season, such as immediately before planting, rye can deplete soil water content, causing reductions in yield (Liebl et al., 1992). Also, destroying rye immediately before the cash crop could expose the new crop to the harmful effects of allelopathy (Yenish et al., 1995). As more research is done in this field, there will be fewer barriers to using rye as a cover crop, which may result in greater crop yields and healthier soil. 


\subsubsection{COMPOST FOR ORGANIC CROPS}

Surveys of organic farmers indicate that soil fertility is the biggest challenge in organic grain production after weed control (Walz, 2004). A fertilizer which meets federal organic standards must be utilized (AMS, 2014). A commonly used fertilizer is compost.

Compost is the compilation of decomposed or partially decomposed organic amendments such as food, plant, and animal wastes (Baldwin and Greenfield, 2006). The opportunity to utilize compost offers an alternative to urban area of disposing of organic matter in landfills and to the livestock industry which has an excess of animal waste. This organic waste from both urban cities and livestock operations can be used by the organic agriculture industry, which has a need for a non-synthetic fertilizer (Smiciklas et al., 2008).

Compost offers many benefits to soil health. It provides macro and micronutrients such as P, K, Ca, and Fe (Baldwin and Greenfield, 2006; Steiner et al., 2007). Soil surface $\mathrm{C}$ and $\mathrm{N}$ concentrations also may improve with compost applications (Eghball, 2002). Nutrients are not released as quickly as those supplied by synthetic fertilizers, thus mineralization of $\mathrm{N}$ occurs more slowly (Stamatiadis et al., 1999). Compost can increase soil pH and cation exchange capacity (Ouédraogo et al., 2001). The high cation exchange capacity of organic amendments may help stabilize soil nutrients (Stamatiadis et al., 1999). Additionally, compost can decrease bulk density and penetration resistance, and increase aggregate stability, porosity, soil organic carbon, water holding capacity, and infiltration rate (Cogger, 2005; Giusquiani et al., 1995; Khaleel et al., 1981; Martens and 
Frankenberger, 1992). The greatest accumulation of organic C occurs with the addition of stabilized amendments such as compost (Haynes and Naidu, 1998).

The effect of increasing water holding capacity with organic amendments may be especially important during periods of drought. Water holding capacity is increased at both low and high water tensions through the increased porosity and surface area resulting from organic amendments (Gupta and Larson, 1979; Khaleel et al., 1981). However, while plant available water may increase with higher rates of compost, this effect may only be noticed after several years of application, as it takes time for the organic matter associated with compost to build up in the soil (Giusquiani et al., 1995).

Compost may be an especially important tool for organic producers utilizing NT, as it can increase soybean yields and thus help to eliminate yield differences between conventional and NT systems, although multiple applications may be necessary (Singer et al., 2004).

This organic fertilizer does come with an economic cost, and it is not always clear how much compost is needed for certain crops in specific growing conditions. Little research has been done on the ideal quantity of compost for growing soybean, although this investigation attempts to address that issue.

\subsection{GREENHOUSE GASES: A BRIEF INTRODUCTION}

A GHG is any gas that when present in the atmosphere traps heat from the sun that has reflected off the Earth's surface. The effect of this trapped heat is a purported overall slight increase in the Earth's temperature by a magnitude of 1-3 degrees $\mathrm{F}^{\circ}$, a phenomenon that can contribute to climate change. The three gases recognized to have 
the largest impact on climate change are carbon dioxide $\left(\mathrm{CO}_{2}\right)$, nitrous oxide $\left(\mathrm{N}_{2} \mathrm{O}\right)$, and methane $\left(\mathrm{CH}_{4}\right)(\mathrm{EPA}, 2013)$. The amount and climatic impact of these three gases varies considerably. There were 5,730 million metric tons of $\mathrm{CO}_{2}$ emitted during 2010 in the United States. This was $84 \%$ of total U.S. emissions, making $\mathrm{CO}_{2}$ the most emitted greenhouse gas (EPA, 2013). It is naturally present in the atmosphere through the C cycle, in which $\mathrm{C}$ is circulated through the oceans, soil, plants, and animals. However, human activity has within the past 200 years added large amounts of $\mathrm{CO}_{2}$ to the atmosphere through the burning of fossil fuels and plant matter. Methane made up 10\% of US emissions in 2010, and is primarily emitted through the burning of natural gas and domestic livestock production. Methane emissions from grain crop production are very low compared to livestock production (EPA, 2013) and it is for this reason that methane is not discussed further in this review.

The third major greenhouse gas, nitrous oxide $\left(\mathrm{N}_{2} \mathrm{O}\right)$, contributed a mere $4 \%$ of emissions in 2010 in the U.S. However, a better way to evaluate the impact of a GHG is not by mass loss but by the relative contribution a gas makes in trapping heat within the earth's atmosphere. One pound of $\mathrm{N}_{2} \mathrm{O}$ is over 300 times more effective at trapping reflected heat than a pound of $\mathrm{CO}_{2}$ (Forster et al., 2007). So although mass emissions of $\mathrm{N}_{2} \mathrm{O}$ are small, the impact those emissions have on warming the atmosphere is large (EPA, 2013). $\mathrm{N}_{2} \mathrm{O}$ is very efficient at absorbing infrared radiation, which is why it has a significant influence on the chemistry of the stratosphere and on the earth's thermal balance (He et al., 2001).

Because the science behind the impact of GHG still has some uncertainties, it is difficult to predict the long-term impact of GHG. Still, because of the growing 
recognition by governments and the general public that climate change is occurring, it is likely that national policies aimed at limiting GHG emissions will be enacted in the near future (Antle and Ogle, 2012). Therefore, it may be prudent for all industries, including that of agriculture, to target and limit GHG emissions (Grubb, 1990).

\subsubsection{AGRICULTURE EFFECTS ON GHG}

Agriculture is the principle human-related source of $\mathrm{N}_{2} \mathrm{O}$ emissions and also contributes large quantities of $\mathrm{CO}_{2}$ to the atmosphere (EPA, 2013; Robertson et al., 2000). Globally, $65 \%$ of $\mathrm{N}_{2} \mathrm{O}$ emissions originate from agricultural soils through the processes of nitrification and denitrification (Paul, 1997). Nitrification is the process in which ammonia $\left(\mathrm{NH}_{3}\right)$ is oxidized by autotrophic bacteria into nitrite $\left(\mathrm{NO}_{2}{ }^{-}\right)$, of which most is then converted into nitrate $\left(\mathrm{NO}_{3}{ }^{-}\right)$(Brady and Weil, 2010). Under aerobic conditions these chemicals, $\mathrm{NO}_{3}{ }^{-}$and $\mathrm{NO}_{2}{ }^{-}$, may then transform into $\mathrm{N}_{2} \mathrm{O}$ (Bremner and Blackmer, 1978). Nitrous oxide, as well as $\mathrm{NO}_{3}{ }^{-}$and $\mathrm{N}_{2}$, is also released during denitrification of $\mathrm{NO}_{2}{ }^{-}$and $\mathrm{NO}_{3}{ }^{-}$by heterotrophic bacteria (Follett and Delgado, 2002). Nitrification and denitrification are highly dependent on the nitrifying and denitrifying bacteria which actually perform the biochemical process. Higher rates of bacterial growth and activity lead to increased emissions of $\mathrm{N}_{2} \mathrm{O}$ (Lesschen et al., 2011). The rate of $\mathrm{N}_{2} \mathrm{O}$ production is also affected by the availability of oxygen $\left(\mathrm{O}_{2}\right)$. Environmental conditions with an abundance or minimal $\mathrm{O}_{2}$ limit $\mathrm{N}_{2} \mathrm{O}$ production. However, at moderate $\mathrm{O}_{2}$ concentrations, denitrification and nitrification occur simultaneously, and it is this condition in which $\mathrm{N}_{2} \mathrm{O}$ is mainly produced (Brady and Weil, 2010; He et al., 2001). 
Soil emissions of $\mathrm{N}_{2} \mathrm{O}$ are highly dependent upon multiple soil factors including $\mathrm{NH}_{4}{ }^{+}$and $\mathrm{NO}_{3}{ }^{-}$concentrations, water content, temperature, $\mathrm{pH}$, available $\mathrm{C}$, aeration, and time of year (MacKenzie et al., 1997; Raich and Potter, 1995). Spring thaw represents as much as $93 \%$ of total (summer and spring) $\mathrm{N}_{2} \mathrm{O}$ losses (Lemke et al., 1999). When soil temperatures are low $\left(<12^{\circ} \mathrm{C}\right)$, differences in emissions tend to be minimal (MacKenzie et al., 1997). Losses of $\mathrm{N}_{2} \mathrm{O}$ also depend on type, form, and timing of inorganic fertilizer application, quality and composition of residue, and cultivation (Baggs et al., 2003).

Carbon dioxide emissions from agriculture soils are also significant. Carbon dioxide is released in large part due to microbial decay, burning of plant matter, and respiration of both soil organisms and plant roots (Raich and Potter, 1995, Smith et al., 2008). It is also released to a small extent through the chemical oxidation of carboncontaining materials (Lundegårdh, 1927). Soil microorganisms use assimilated C for cell synthesis and energy. This $\mathrm{C}$ is consumed at variable rates depending on the biomass and relative growth rate of the microorganism populations $(\mathrm{Li}, 1992)$. The difference between this amount of consumed $\mathrm{C}$ and the amount used for cell synthesis equals the production of $\mathrm{CO}_{2}$ from soil microorganisms (Baggs et al., 2003). Soil $\mathrm{CO}_{2}$ emissions vary within and between seasons, with maximum emissions occurring during periods of active plant growth (Raich and Potter, 1995).

Carbon dioxide emissions are affected by SOM, soil and air temperature, soil moisture content, soil type, agricultural management practices, and redox potential (Raich and Potter, 1995; Smith et al., 2008). The rate at which $\mathrm{CO}_{2}$ moves from the soil to the atmosphere is not constant: the rate of $\mathrm{CO}_{2}$ production in the soil, the strength of the concentration gradient between the soil and the atmosphere, and properties such as 
soil pore size, air temperature, and wind speed influence the rate at which $\mathrm{CO}_{2}$ is emitted from the soil (Raich and Schlesinger, 1992)

Many management practices may have an effect on GHG emissions as well. Tillage, fertilization, and irrigation events, as well as climatic events such as precipitation and spring thaw, can release a large proportion of annual $\mathrm{N}_{2} \mathrm{O}$ emissions in a short amount of time (Johnson et al., 2010; Venterea et al., 2011). Closely managing GHG responses during these events, which can occur over a period of hours, days, or weeks, could significantly decrease annual GHG production (Venterea et al., 2012). Also, conducting tillage under cool and dry conditions may help to mitigate emissions (Baggs et al., 2000). By understanding the conditions which lead to greater GHG on soils, action can be taken to mitigate those emissions to the lowest possible levels.

\subsubsection{SOIL NitROGEN EFFECTS ON GHG}

The addition of chemical or organic $\mathrm{N}$ fertilizers contributes to the majority of agricultural related $\mathrm{N}_{2} \mathrm{O}$ emissions (Johnson et al., 2007; Paul, 1997; Venterea et al., 2011). Not only does $\mathrm{N}_{2} \mathrm{O}$ production from agricultural activities represent a threat to the condition of the atmosphere, it also indicates economic loss. Fertilizer N, an expensive addition to cropland, is not being utilized completely when it is lost as $\mathrm{N}_{2} \mathrm{O}$. It is a fundamental challenge in agriculture to maximize crop utilization of fertilizer $\mathrm{N}$, as major US crops typically do not take up more than 40-50\% of applied N (Cavigelli et al., 2012). Both denitrification and nitrification are stimulated when $\mathrm{N}$ exceeds plant requirements 
(Smith et al., 2008). The amount of $\mathrm{N}_{2} \mathrm{O}$ emitted is correlated with the amount of nitrifiable $\mathrm{N}$ in the soil (Li, 1992).

Nitrous oxide emissions differ between mineral and organic based fertilizers. Organic fertilizers have been shown to cause lower $\mathrm{N}_{2} \mathrm{O}$ emissions than chemical fertilizers (Akiyama et al., 2004; Bouwman et al., 2002; Lesschen et al., 2011). The reason for this may be because higher levels of nitrifiable $\mathrm{N}$ are available to bacteria in chemical fertilizers. Nitrous oxide emissions increase as larger amounts of easily mineralizable $\mathrm{N}$, characteristic of conventional $\mathrm{N}$-fertilizer, are applied to the soil (Lesschen et al., 2011; MacKenzie et al., 1997). Although compost may initially have high $\mathrm{NO}_{3}{ }^{-}$content, soil amended with compost quickly reaches low levels of $\mathrm{NO}_{3}{ }^{-}$due to net loss through leaching, root uptake, and denitrification (Stamatiadis et al., 1999, Steiner et al., 2007).

Soil temperature has a profound effect on $\mathrm{N}_{2} \mathrm{O}$ emissions. As the temperature lowers, nitrifying and denitrifying bacteria activity slows, followed by a decrease in the ratio between $\mathrm{N}_{2} \mathrm{O}$ and mineral $\mathrm{N}$. Then as soil temperature increases, $\mathrm{N}_{2} \mathrm{O}$ emissions also increase, due to an increase in microbial activity. This is because higher temperatures lead to greater $\mathrm{O}_{2}$ consumption and thus higher anaerobic bacteria activity (Lesschen et al., 2011).

\subsubsection{SOIL ORgANic MATTER EFFECTS ON GHG}

Soil organic matter affects $\mathrm{CO}_{2}$ and $\mathrm{N}_{2} \mathrm{O}$ emissions (Lesschen et al., 2011). This is due to a number of soil processes. Anaerobic bacteria which cause denitrification and 
promote $\mathrm{N}_{2} \mathrm{O}$ production are more abundant in soils of higher organic matter (Johnson et al., 2007). In fact, it is the decomposition of organic matter and other oxidation reactions which dominate $\mathrm{N}_{2} \mathrm{O}$ production, at least between rainfall events ( $\left.\mathrm{Li}, 1992\right)$. Carbon dioxide may also increase with greater SOM.

Soil organic matter is the main source of $\mathrm{CO}_{2}$ emissions in agriculture (Smith et al., 2008). Decomposition of plant matter and the subsequent release of $\mathrm{CO}_{2}$ is part of the $\mathrm{C}$ cycle, in which plants use $\mathrm{CO}_{2}$ in the atmosphere for growth and store it in their tissue as fixed, organic C. It remains there until the plant dies, and then is released again as a gas when microbes slowly break it down. Carbon dioxide is also released as deceased microbes decompose (Li, 1992). Soil temperature also affects these processes. Annual $\mathrm{CO}_{2}$ emissions may increase by $13 \%$ with a $20 \%$ increase in soil temperature (Li, 1992).

Although these emissions from soils are small in comparison to the millions of tons emitted through the burning of fossil fuels, the physical processes involved in $\mathrm{CO}_{2}$ creation can be exploited to make a significant reduction in atmospheric $\mathrm{CO}_{2}$ levels. The $\mathrm{CO}_{2}$ used by plants as part of the $\mathrm{C}$ cycle can be harnessed and stored in living or dead plant tissue.

\subsubsection{CARbon SEQUESTRATION vS CARbon EMisSiOnS}

Agriculture has been promoted as a potential tool for slowing global warming through soil $\mathrm{C}$ sequestration. Carbon sequestration is the long-term storage of $\mathrm{C}$ in the soil (ESA, 2000). By encouraging plant growth and increasing the photosynthetic input of $\mathrm{C}$ through proper agricultural management, significant amounts of $\mathrm{C}$ can be sequestered 
in the soil through additions of organic matter (Smith et al., 2008; Snyder et al., 2009). Although $\mathrm{C}$ can come in many forms, SOM is the main form in the soil and mean residence time of "stable" or "long-lived" SOM varies from 250 to 1,900 years (Johnson et al., 2007). The amount of carbon contained in soil organic matter is much larger than the atmospheric $\mathrm{CO}_{2}-\mathrm{C}$ pool (Raich and Potter, 1995).

Microbial degradation breaks down $\mathrm{C}$ and converts it into $\mathrm{CO}_{2}$. This process can be prevented if the $\mathrm{C}$ is protected within stable microaggregates $(<250 \mu \mathrm{m})$, adsorbed onto the inner surface of clays, or be chemically protected in organo-mineral complexes (Johnson et al., 2007). Areas with higher clay content such as those typical of clay-pan soils may thus help prevent soil $\mathrm{C}$ from degrading. The residence time of SOM tends to increase with depth in the soil profile and is also affected by the type of clay. Kaolinite and other 1:1 clays have a shorter turnover time than 2:1 clays like smectite (Johnson et al., 2007).

Management practices that increase organic matter, such as cover cropping or the use of compost as a fertilizer, enhance microbial functions and promote SOC sequestration (Jarecki and Lal, 2003). No-till systems with conventional inputs can gain $30 \mathrm{~g} \mathrm{C} \mathrm{m}^{-2}$ year ${ }^{-1}$ and organic-based systems may gain 8 to $11 \mathrm{~g} \mathrm{C} \mathrm{m}^{-2}$ year $^{-1}$ while conventionally managed systems which including tillage and synthetic fertilizer may not make gains in soil C (Grandy, 2006; Robertson et al., 2000). Reduced tillage and the use of cover crops may sequester soil $\mathrm{C}$ through the prevention of soil erosion (Archer et al., 2007; Johnson et al., 2007; Lemke et al., 1999; Robertson et al., 2000). 


\subsubsection{TILLAGE EFFECTS ON GHG}

Organic agriculture is assumed to have minimal impacts on the environment when compared to conventional agriculture. However, because synthetic pesticides cannot be used, tillage is often employed to destroy weeds. Not only can tillage cause unwanted compaction and increase bulk density in the long term, it can stimulate an increase in greenhouse gases (GHG) (Antle and Ogle, 2012).

Results characterizing the relationship between GHG emissions and tillage regime vary considerably. In regards to $\mathrm{N}_{2} \mathrm{O}$, some studies have found $\mathrm{CT}$ to result in higher emissions than NT (Lemke et al., 1999; Malhi et al., 2006). Losses of $\mathrm{N}_{2} \mathrm{O}$ can be between four and six times greater for CT during the spring thaw period than NT (Lemke et al., 1999). Tillage can release a large proportion of annual GHG emissions in a short amount of time (Johnson et al., 2010). Carbon dioxide may also increase with CT (Antle and Ogle, 2012; Smith et al., 2008). There is evidence that in the short term, tillage induces $\mathrm{CO}_{2}$ production proportional to the volume of soil disturbed (Reicosky and Archer, 2007).

Although the previous studies found GHG emissions to increase with CT, other studies have found emissions of $\mathrm{CO}_{2}$ and $\mathrm{N}_{2} \mathrm{O}$ to increase in NT systems (Baggs et al., 2003; Ball et al., 1999; Elmi, 2003; Grandy, 2006; MacKenzie et al., 1997; Robertson et al., 2000; Smith et al., 2008). The higher flux is attributed to greater soil moisture content observed in NT soils (MacKenzie et al., 1997). Crop residue accumulates on the surface of NT systems which reduces evaporation and increases soil moisture content, conditions that stimulate GHG losses (Baggs et al., 2003; MacKenzie et al., 1997). Also, NT may 
increase denitrification activity due to a greater amount of oxidizable $\mathrm{C}$ at or near the surface soil of NT treatments, thereby increasing microbial activity and GHG emissions associated with denitrification (Baggs et al., 2003; Staley et al., 1990). If cover crops are used, additional plant residue is introduced which increases the number of anaerobic micro-sites, thereby creating conditions favorable to GHG production (Lemke et al., 1999).

Still other studies have found that no differences in GHG emissions may occur between NT and CT systems (Marland et al., 2001; Robertson et al., 2000; Smith et al., 2008). It would seem that the effect of tillage regiment on GHG emissions varies considerably. This is likely due to variations in soil and management differences.

A study with various $\mathrm{N}$ treatments found that although $\mathrm{N}_{2} \mathrm{O}$ emissions were not significantly affected by tillage, when expressed as loss per units of grain yield, a NT system would generate more $\mathrm{N}_{2} \mathrm{O}$ than a CT system (Venterea et al., 2011). The implication of this is that although GHG emissions may vary between two management treatments, crop yield must also be taken into account to obtain an accurate portrayal of the amount of GHG emitted per unit of grain. An analogy for this idea would be that of two factories that produce identical toys. One of the factories is able to produce the toy with only half of the GHG emissions as the other factory. However the factory which emits more GHG emissions is more efficient at production, and can produce four times as many toys as the cleaner factory in the same amount of time. So the cleaner factory must operate four times as long to produce the same amount of toys as the dirtier factory. Thus during this extended production period, the "cleaner" factory eventually releases more GHG emissions per unit of toy than is produced by the "dirtier" factory. 
In the same way, although GHG emissions may be higher for a particular crop production system, yield must be taken into account when considering net emissions. Even though one system may seem to result in less GHG emissions, if that system can only produce $75 \%$ of the grain that an alternative system can produce, then $33 \%$ more land would be needed to grow the same amount of grain. An overall greater amount of GHG may then be released on this larger area of land.

A study which took into account multiple factors when estimating the difference in global warming potential (GWP) between a NT and CT system was that performed by Robertson et al. (2000). Four corn-wheat-soybean rotations were managed over a decade. They measured $\mathrm{N}_{2} \mathrm{O}$ production, $\mathrm{CH}_{4}$ oxidation, and soil $\mathrm{C}$ sequestration on fields that were (i) conventionally managed with chemical inputs and tillage, (ii) with conventional inputs but no tillage, (iii) with reduced chemical inputs and tillage, and (iv) organically managed with tillage. The systems associated with CT exhibited a net GWP of $114 \mathrm{~g} \mathrm{CO}_{2}$ equivalents $\mathrm{m}^{-2}$ year $^{-1}$. About half of this was attributed to $\mathrm{N}_{2} \mathrm{O}$ production, and half to the combined effects of fertilizer and lime. Fuel use was also significant in its emission of $\mathrm{CO}_{2}$ but was less than that of lime or fertilizer. The net GWP of the NT system however, was much lower at only $14 \mathrm{~g} \mathrm{CO}_{2}$ equivalents $\mathrm{m}^{-2}$ year $^{-1}$. Emissions of $\mathrm{N}_{2} \mathrm{O}$ and $\mathrm{CO}_{2}$ were almost completely offset by the increased C storage in NT soils. Lower fuel costs were offset by slightly higher $\mathrm{N}_{2} \mathrm{O}$ fluxes and lime inputs. The low-input and organicbased systems exhibited an intermediate net GWP of 41 to $63 \mathrm{~g} \mathrm{CO}_{2}$ equivalents $\mathrm{m}^{-2}$ year${ }^{1}$, about half of the CT system. These two systems did sequester C, however, the increased $\mathrm{N}_{2} \mathrm{O}$ production effectively raised net GWP of the CT system to a much higher level than that of the NT system. The study concluded that although agriculture plays a 
relatively minor role in the GWP economy of the country, net mitigation of agricultural fluxes could offset the annual increase in fossil fuel emissions. This could be accomplished by soil C storage through NT management and use of cover crops. Substituting synthetic $\mathrm{N}$ fertilizer with biological $\mathrm{N}_{2}$ fixation through leguminous cover crops also reduced net GWP. Finally, tightening the N cycle of cropping systems is essential to reducing emissions (Johnson et al., 2007).

\subsubsection{Soil Properties That Promote GHG}

Greenhouse gas emissions are affected by soil characteristics. Soil with greater water holding properties, including those with a high prevalence of organic matter, release larger volumes of $\mathrm{N}_{2} \mathrm{O}$ when water has recently been available (Lesschen et al., 2011). This is due to the increased activity of anaerobic bacteria, which are more active when the soil is at higher moisture content. Peat soils in particular tend to emit extremely high volumes of $\mathrm{N}_{2} \mathrm{O}$ because of the high organic content which characterizes these soils (Lesschen et al., 2011). However, the effect that soils with greater water holding capacities have on GHG emissions is reduced when soil water content is low.

The research detailed in this thesis was conducted on a claypan soil in central Missouri, which is within the Central Claypan Area of the United States (NRCS, 2006). This soil is characterized by the consistent presence of an underlying claypan horizon. The layer of clay throughout this horizon has at least 100\% more clay than the superior horizon. Claypan soil often contains $45 \%$ to $65 \%$ clay. The depth to the claypan varies depending on topography, ranging from $10 \mathrm{~cm}$ on eroded backslopes to $100 \mathrm{~cm}$ or more 
on depositional footslope areas (Myers et al., 2007). While the claypan layer does contain high concentrations of cations and organic matter (Bray, 1935), it also hinders water and air movement. Soybean yield in claypan soils is affected by soil properties and landscape position (Myers, Kitchen, et al., 2007). As the depth to claypan varies across a landscape, yield may vary as well.

\subsubsection{SoIL MoISTURE CONTENT EFFECTS ON GHG}

Greater soil moisture content leads to greater $\mathrm{N}_{2} \mathrm{O}$ and $\mathrm{CO}_{2}$ emissions (Akiyama et al., 2004; MacKenzie et al., 1997). Available water within the soil is necessary for plant growth as well as growth and activity of bacteria and other microbes. Anaerobic bacteria in particular thrive in soil of high moisture. Because many anaerobic bacteria are involved in the denitrification transformation, increased levels of $\mathrm{N}_{2} \mathrm{O}$ emissions can be expected as precipitation rises and wet conditions persist. Indeed, it is during rainfall events that the process of denitrification dominates $\mathrm{N}_{2} \mathrm{O}$ production ( $\left.\mathrm{Li}, 1992\right)$. Positive fluxes in GHG occur after rainfall and irrigation events (Akiyama et al., 2004; Grandy, 2006; MacKenzie et al., 1997).

Wetlands, which tend to contain soils with high moisture content, contain more $\mathrm{CO}_{2}$ than any other ecological system (Paul, 1997). However, environments that remained flooded for a prolonged period of time may slow organic matter decomposition and thus $\mathrm{CO}_{2}$ and $\mathrm{N}_{2} \mathrm{O}$ production ( $\mathrm{Yu}$ et al., 2006). 


\subsection{REFERENCES}

Akiyama, H., McTaggart, I. P., Ball, B. C., and Scott, A. 2004. N2O, NO, and NH3 emissions from soil after the application of organic fertilizers, urea and water. Water, Air, and Soil Pollut. 156:113-129.

AMS. 2014. National List of Allowed and Prohibited Substances. USDA. http://www.ams.usda.gov/AMSv1.0/NOPPetitionedSubstancesDatabase

Antle, J. M., and Ogle, S. M. 2012. Influence of soil C, N2O and fuel use on GHG mitigation with no-till adoption. Clim. Change 111:609-625.

Archer, D. W., Jaradat, A. A., Johnson, J. M., Weyers, S. L., Gesch, R. W., Forcella, F., and Kludze, H. K. 2007. Crop productivity and economics during the transition to alternative cropping systems. Agron. J. 99:1538-1547.

Baggs, E., Rees, R., Smith, K., and Vinten, A. 2000. Nitrous oxide emission from soils after incorporating crop residues. Soil Use Manage. 16:82-87.

Baggs, E. M., Stevenson, M., Pihlatie, M., Regar, A., Cook, H., and Cadisch, G. 2003. Nitrous oxide emissions following application of residues and fertiliser under zero and conventional tillage. Plant Soil 254:361-370.

Baldwin, K. R., and Greenfield, J. T. 2006. Composting on organic farms. Center for Environmental Farming Systems. North Carolina Extension Service, North Carolina.

Ball, B. C., Scott, A., and Parker, J. P. 1999. Field N2O, CO2 and CH 4 fluxes in relation to tillage, compaction and soil quality in Scotland. Soil and Tillage Res. 53:29-39.

Berner, A., Hildermann, I., Fließbach, A., Pfiffner, L., Niggli, U., and Mäder, P. 2008. Crop yield and soil fertility response to reduced tillage under organic management. Soil Tillage Res. 101:89-96.

Bernstein, E. R., Posner, J. L., Stoltenberg, D. E., and Hedtcke, J. L. 2011. Organically Managed No-Tillage Rye-Soybean Systems: Agronomic, Economic, and Environmental Assessment. Agron. J. 103:1169-1179.

Bouwman, A., Boumans, L., and Batjes, N. 2002. Modeling global annual N2O and NO emissions from fertilized fields. Global Biogeochemical Cycles 16:28-1-28-9.

Brady, N.C. and R.R. Weil. 2010. Elements of the nature and properties of soils. Pearson Educational International. Upper Saddle River, NJ. 
Bray, R. 1935. The Orgins of Horizons in Claypan Soils. Soil Sci. Soc. Am. J. B16:7075.

Bremner, J. M., and Blackmer, A. M. 1978. Nitrous Oxide: Emission from Soils During Nitrification of Fertilizer Nitrogen. Science 199:295-296.

Cavigelli, M. A., Grosso, S. J. D., Liebig, M. A., Snyder, C. S., Fixen, P. E., Venterea, R. T., Leytem, A. B., McLain, J. E., and Watts, D. B. 2012. US Agricultural Nitrous Oxide Emissions: Context, Status, and Trends. Front. Eco. Envir. 10:537-546.

Cavigelli, M. A., Teasdale, J. R., and Conklin, A. E. 2008a. Long-Term Agronomic Performance of Organic and Conventional Field Crops in the Mid-Atlantic Region Agron. J. 100:785-794.

Cavigelli, M. A., Teasdale, J. R., and Conklin, A. E. 2008b. Long-Term Agronomic Performance of Organic and Conventional Field Crops in the Mid-Atlantic Region. Agron. J. 100: 785-794.

Clark, A. 2008. Managing cover crops profitably. 3 Ed. Sustainable Agriculture Network. DIANE Publishing, Beltsville, MD.

Cogger, C. G. 2005. Potential compost benefits for restoration of soils disturbed by urban development. Compost Sci. 13: 243-251.

Colquhoun, J. B. 2006. Allelopathy in weeds and crops: myths and facts. Proc. of the 2006 Wisconsin Fertilizer, Aglime \& Pest Management Conference 45.

Delate, K., Cwach, D., and Chase, C. 2012. Organic no-tillage system effects on soybean, corn and irrigated tomato production and economic performance in Iowa, USA. Renewable Agriculture and Food Systems 27: 49-59.

Eghball, B. 2002. Soil Properties as Influenced by Phosphorus- and Nitrogen-Based Manure and Compost Applications. Agron. J. 94: 128-135.

Elmi, A. A., C. Madramootoo, C. Hamel, and A. Liu 2003. Denitrification and $\mathrm{N}_{2} \mathrm{O}$ plus dinitogen ratios in the soil profile under three tillage systems. Biol. Fertil. Soils 38: 340-348.

EPA 2013. Sources of Greenhouse Gas Emissions. United States Environmental Protection Agency. http://www.epa.gov/climatechange/ghgemissions/ sources.html

Epplin, F., Hossain, I., and Krenzer Jr, E. 2000. Winter wheat fall-winter forage yield and grain yield response to planting date in a dual-purpose system. Agric. Sys. 63: $161-173$. 
ESA 2000. Carbon Sequestration in Soils. Ecological Society of America. Washington, DC.http://www.esa.org/esa/wpcontent/uploads/2012/12/carbonsequestrationinsoil s.pdf

Ferguson, J. J., and Rathinasabapathi, B. 2003. Allelopathy: How plants suppress other plants. University of Florida Cooperative Extension Service. Institute of Food and Agricultural Sciences, EDIS.

Follett, R. F., and Delgado, J. A. 2002. Nitrogen fate and transport in agricultural systems. J. Soil and Water Conserv. 57: 402-407.

Forster, P., Ramaswamy, V., Artaxo, P., Berntsen, T., Betts, R., Fahey, D. W., Haywood, J., Lean, J., Lowe, D. C., and Myhre, G. 2007. Changes in atmospheric constituents and in radiative forcing. Climate change 20:121-128.

Giusquiani, P., Pagliai, M., Gigliotti, G., Businelli, D., and Benetti, A. 1995. Urban waste compost: effects on physical, chemical, and biochemical soil properties. J. Envir. Qual. 24: 175-182.

Grandy, A. S., T.D. Loecke, S. Parr, and G. P. Robertson 2006. Long-Term Trends in $\mathrm{N}_{2} \mathrm{O}$ Emissions, Soil Nitrogen, and Crop Yields of Till and No-Till Cropping Systems. J. Envir. Qual. 35:1487-1495

Grubb, M. 1990. The Greenhouse Effect: Negotiating Targets. International Affairs Royal Institute of International Affairs 66: 67-89.

Gupta, S., and Larson, W. 1979. Estimating soil water retention characteristics from particle size distribution, organic matter percent, and bulk density. Water Resour. Res. 15: 1633-1635.

Haynes, R., and Naidu, R. 1998. Influence of lime, fertilizer and manure applications on soil organic matter content and soil physical conditions: a review. Nut. Cyc. Agroeco. 51: 123-137.

He, Y., Inamori, Y., Mizuochi, M., Kong, H., Iwami, N., and Sun, T. 2001. Nitrous oxide emissions from aerated composting of organic waste. Environ. Sci. Technol. 35: 2347-2351.

Ingels, C. A. 1998. Cover cropping in vineyards: a grower's handbook. Vol 338. UCANR Publications. University of California. Division of Agriculture and Natural Resources.

Jarecki, M. K., and Lal, R. 2003. Crop management for soil carbon sequestration. Crit. Rev. Plant Sci. 22: 471-502. 
Johnson, J. M., Archer, D., and Barbour, N. 2010. Greenhouse gas emission from contrasting management scenarios in the northern Corn Belt. Soil Sci. Soc. Am. J. 74: 396-406.

Khaleel, R., Reddy, K., and Overcash, M. 1981. Changes in soil physical properties due to organic waste applications. J. Environ.l Qual. 10: 133-141.

Lal, R. 1997. Residue management, conservation tillage and soil restoration for mitigating greenhouse effect by CO2 enrichment. Soil Tillage Res. 43: 81-107.

Lemke, R. L., Izaurralde, R. C., Nyborg, M., and Solberg, E. D. 1999. Tillage and N source influence soil-emitted nitrous oxide in the Alberta Parkland region. Can. J. Soil Sci. 79: 15-24.

Lesschen, J. P., Velthof, G. L., de Vries, W., and Kros, J. 2011. Differentiation of nitrous oxide emission factors for agricultural soils. Environ. Pollut. 159: 3215-3222.

Li, C., S Frolking, TA Frolkin 1992. A model of nitrous oxide evolution from soil driven by rainfall events: I. model structure and sensitivity. J. Geophys. Res. 97:97599776.

Liebl, R., Simmons, F. W., Wax, L. M., and Stoller, E. W. 1992. Effect of rye (secale cereale) mulch on weed control and soil moisture in soybean (glycine max). Weed Tech. 6: 838-846.

Lundegårdh, H. 1927. Carbon dioxide evolution of soil and crop growth. Soil Sci. 23: 417-453.

MacKenzie, A. F., Fan, M. X., and Cadrin, F. 1997. Nitrous oxide emission as affected by tillage, corn-soybean-alfalfa rotations and nitrogen fertilization. Can. J. Soil Sci. 77: 145-152.

Malhi, S. S., Lemke, R., Wang, Z. H., and Chhabra, B. S. 2006. Tillage, nitrogen and crop residue effects on crop yield, nutrient uptake, soil quality, and greenhouse gas emissions. Soil and Tillage Res. 90: 171-183.

Marland, G., McCarl, B., and Schneider, U. 2001. Soil Carbon: Policy and Economics. Climatic Change 51: 101-117.

Martens, D., and Frankenberger, W. 1992. Modification of infiltration rates in an organicamended irrigated. Agron. J. 84: 707-717.

McBride, W. D., and Greene, C. 2009. The profitability of organic soybean production. Renew. Ag. Food Sys. 24: 276-284. 
Myers, D. B., Kitchen, N. R., Sudduth, K. A., Sharp, R. E., and Miles, R. J. 2007. Soybean root distribution related to claypan soil properties and apparent soil electrical conductivity. Crop Sci. 47: 1498-1509.

Nelson, K. A., Smeda, R. J., and Smoot, R. L. 2011. Spring-Interseeded Winter Rye Seeding Rates Influence Weed Control and Organic Soybean Yield. Intern. J. Agron. 45:498-509.

NRCS. 2006. Land resource regions and major land resource areas of the United States, the Caribbean, and the Pacific Basin. US Department of Agriculture Handbook 296.

Ouédraogo, E., Mando, A., and Zombré, N. 2001. Use of compost to improve soil properties and crop productivity under low input agricultural system in West Africa. Agric. Ecosys. Envir. 84:259-266.

Paul, E. A. 1997. Soil organic matter in temperate agroecosystems: Long-term experiments in North America. CRC Press. Boca Raton, FL.

Pimentel, D., Hepperly, P., Hanson, J., Douds, D., and Seidel, R. 2005. Environmental, energetic, and economic comparisons of organic and conventional farming systems. BioScience 55:573-582.

Pitcock, J. 2013. USDA Livestock, Poultry and Grain Market News. National Organic Grain and Feedstuffs Bi-Weekly. http://www.ams.usda.gov/AMSv1.0/ lpsmarketnewspage

Place, G. T., Reberg-Horton, S. C., and Burton, M. G. 2009. Effects of preplant and postplant rotary hoe use on weed control, soybean pod position, and soybean yield. Weed Sci. 57:290-295.

Przepiorkowski, T., and Gorski, S. F. 1994. Influence of rye (Secale cereale) plant residues on germination and growth of three triazine-resistant and susceptible weeds. Weed Tech. 28:744-747.

Qasem, J., and Foy, C. 2001. Weed allelopathy, its ecological impacts and future prospects. J. Crop Prod. 4: 43-119.

Raich, J., and Schlesinger, W. H. 1992. The global carbon dioxide flux in soil respiration and its relationship to vegetation and climate. Tellus B. 44:81-99.

Raich, J. W., and Potter, C. S. 1995. Global patterns of carbon dioxide emissions from soils. Glob. Biogeo. Cyc. 9:23-36.

Reicosky, D., and Archer, D. 2007. Moldboard plow tillage depth and short-term carbon dioxide release. Soil and Tillage Res. 94:109-121. 
Robertson, G. P., Paul, E. A., and Harwood, R. R. 2000. Greenhouse gases in intensive agriculture: contributions of individual gases to the radiative forcing of the atmosphere. Science 289: 1922-1925.

Ryan, M., Smith, R., Mortensen, D., Teasdale, J., Curran, W., Seidel, R., and Shumway, D. 2009. Weed-crop competition relationships differ between organic and conventional cropping systems. Weed Res. 49:572-580.

Salinas-Garcia, J., Hons, F., and Matocha, J. 1997. Long-term effects of tillage and fertilization on soil organic matter dynamics. Soil Sci. Soc. Am. J. 61: 152-159.

Service, E. R. 2012. Certified organic and total U.S. acreage, selected crops and livestock, 1995-2008. http://www.ers.usda.gov/data-products/organicproduction.aspx\#.U1AiiFVdXVU

Singer, J. W., Kohler, K. A., Liebman, M., Richard, T. L., Cambardella, C. A., and Buhler, D. D. 2004. Tillage and Compost Affect Yield of Corn, Soybean, and Wheat and Soil Fertility Trade. Agron. J. 96:531-537.

Smiciklas, K., Walker, P., and Kelley, T. 2008. Evaluation of compost for use as a soil amendment in corn and soybean production. Compost Sci. Util. 16:183-191.

Smith, A. N., Reberg-Horton, S. C., Place, G. T., Meijer, A. D., Arellano, C., and Mueller, J. P. 2010. Rolled Rye Mulch for Weed Suppression in Organic NoTillage Soybean. Weed Sci. 59: 224-231.

Smith, P., Martino, D., Cai, Z., Gwary, D., Janzen, H., Kumar, P., McCarl, B., Ogle, S., O'Mara, F., and Rice, C. 2008. Greenhouse gas mitigation in agriculture. Philosophical Transactions of the Royal Society Bio. Sci. 363: 789-813.

Smith, R. G., Barbercheck, M. E., Mortensen, D. A., Hyde, J., and Hulting, A. G. 2011. Yield and net returns during the transition to organic feed grain production. Agron. J. 103: 51-59.

Snyder, C., Bruulsema, T., Jensen, T., and Fixen, P. 2009. Review of greenhouse gas emissions from crop production systems and fertilizer management effects. Agriculture, Ecosys. Envir. 133:247-266.

Staley, T., Boyer, D., and Caskey, W. 1990. Soil denitrification and nitrification potentials during the growing season relative to tillage. Soil Sci. Soc. Am. J. 54:1602-1608.

Stamatiadis, S., Werner, M., and Buchanan, M. 1999. Field assessment of soil quality as affected by compost and fertilizer application in a broccoli field. App. Soil Ecol. $12: 217-225$. 
Steiner, C., Teixeira, W. G., Lehmann, J., Nehls, T., de Macêdo, J. L. V., Blum, W. E., and Zech, W. 2007. Long term effects of manure, charcoal and mineral fertilization on crop production and fertility on a highly weathered Central Amazonian upland soil. Plant Soil 291:275-290.

Teasdale, J. R., Coffman, C. B., and Mangum, R. W. 2007. Potential Long-Term Benefits of No-Tillage and Organic Cropping Systems for Grain Production and Soil Improvement. Agron. J. 99:1297-1305.

Teasdale, J. R., Mangum, R. W., Radhakrishnan, J., and Cavigelli, M. A. 2004. Weed seedbank dynamics in three organic farming crop rotations. Agron. J. 96:14291435 .

USDA, 2011. 2011 Certified Organic Production Survey. National Agricultural Library. http://usda01.library.cornell.edu/usda/current/OrganicProduction/OrganicProducti on-10-04-2012.pdf

USDA-ERS 2012. Soybean \& Oil Crops. Economic Research Service USDA. http://www.ers.usda.gov/topics/crops/soybeans-oil-crops.aspx\#.U1Acp1VdXVU

Venterea, R. T., Bijesh, M., and Dolan, M. S. 2011. Fertilizer source and tillage effects on yield-scaled nitrous oxide emissions in a corn cropping system. J. Enviro. Qual. 40:1521-1531.

Venterea, R. T., Halvorson, A. D., Kitchen, N., Liebig, M. A., Cavigelli, M. A., Grosso, S. J. D., Motavalli, P. P., Nelson, K. A., Spokas, K. A., and Singh, B. P. 2012. Challenges and opportunities for mitigating nitrous oxide emissions from fertilized cropping systems. Front. Ecol. Environ. 10:562-570.

Walz, E. 2004. Final results of the fourth national organic farmers' survey: Sustaining organic farms in a changing organic marketplace. Organic Farming Research Foundation. Santa Cruz, CA. http://ofrf.org/sites/ofrf.org/files/docs/pdf/4 ${ }^{\text {th }}$ survey_results.pdf

Wood, C., Westfall, D., and Peterson, G. 1991. Soil carbon and nitrogen changes on initiation of no-till cropping systems. Soil Sci. Soc. Am. J. 55:470-476.

Yenish, J. P., Worsham, A. D., and Chilton, W. S. 1995. Disappearance of DIBOAglucoside, DIBOA, and BOA from rye cover crop residue. Weed Sci. 36:18-20.

Yu, K., Faulkner, S. P., and Patrick Jr, W. H. 2006. Redox potential characterization and soil greenhouse gas concentration across a hydrological gradient in a Gulf coast forest. Chemosphere 62:905-914. 
Yussefi, M., and Willer, H. 2007. Organic farming worldwide 2007: overview \& main statistics. The World of Organic Agriculture-Statistics and Emerging Trends 2007: 9-16. 


\section{MANAGEMENT IMPACTS ON GREENHOUSE GAS EMISSIONS FOR ORGANIC SOYBEAN}

\subsection{ABSTRACT}

Agricultural land has been recognized as a significant source of greenhouse gas (GHG) emissions, however GHG release from soils varies according to crop production practices, soil conditions, and weather factors. This study was conducted to determine the effects of tillage, cover crop, and compost rate on the soil release of two GHG, nitrous oxide $\left(\mathrm{N}_{2} \mathrm{O}\right)$ and carbon dioxide $\left(\mathrm{CO}_{2}\right)$, under an organic soybean cropping system grown on a Missouri claypan soil. A corn (Zea mays)-soybean (Glycine max)-wheat (Triticum aestivum) organic cropping system was initiated in 2012 at the University of Missouri Bradford Research Center near Columbia, MO using a randomized complete block, split-plot design with four replications. Each crop was investigated independently with tillage/cover crop combinations as the main plot treatment and compost rate for the split-plot treatment. Tillage/cover crop treatments included tilled without cover crop (Till), tilled with cover crop (TillCC), and no-till with cover crop (NTCC). Compost rates were based on soil-test phosphorous recommendations from the University of Missouri Soil Testing Laboratory. Compost treatments were 0 , half the recommended rate (0.5RR), the recommended rate (RR), and 1.5 times the recommended rate (1.5RR). Gas samples were collected at least once a week during the 2012 and 2013 growing seasons, and several times in succession after significant events such as rain, irrigation, and cultivation. Neither tillage/cover practice nor compost was found to affect either $\mathrm{N}_{2} \mathrm{O}$ or 
$\mathrm{CO}_{2}$ emissions during 2012 or 2013 . This could be attributed to the low levels of measured gas flux. Low emissions may be linked to the drought which occurred during 2012, and below average summer precipitation in 2013. Also, sampling may not have been sufficiently frequent to capture significant fluxes of GHG. Still, the failure to find a relationship between GHG emission and some organic management practices is not without precedent.

\subsection{INTRODUCTION}

Soil emissions of $\mathrm{CO}_{2}$ and $\mathrm{N}_{2} \mathrm{O}$ on agricultural land are an important contributor to the steady increase in atmospheric concentrations of GHG. This rising concentration of planet-warming gases may lead to drastic changes in the Earth's climate over time (EPA, 2013). Mitigation of GHG emissions would help prevent the negative impacts a warmer and more unpredictable climate could have on the environment. Also, by reducing $\mathrm{CO}_{2}$ and $\mathrm{N}_{2} \mathrm{O}$ emissions on agriculture land, producers would be better prepared to benefit from national policies which may reward those who emit less GHG emissions (Antle and Ogle, 2012). For this to occur, policy makers and producers need to know the effect various agricultural management techniques have on fluxes of $\mathrm{CO}_{2}$ and $\mathrm{N}_{2} \mathrm{O}$ emissions.

The soil in this study is characterized by an underlying claypan horizon in central Missouri, which is within the Central Claypan Area of the United States (NRCS, 2006). The layer of clay throughout this horizon has at least 100\% more clay than the superior horizon (Myers et al., 2007). Clayey soils emit lower levels of $\mathrm{N}_{2} \mathrm{O}$ than soils of less clay content (Lesschen et al., 2011), however because of their poorly-drained nature as Epiaqualfs, denitrification to other $\mathrm{N}$ gas species may be significant. The impact that this 
soil may have on GHG emissions must be accounted for when comparing this investigation to similar studies in the future.

Emissions of $\mathrm{CO}_{2}$ are affected by soil organic matter (SOM), soil moisture content, soil series, agricultural management practices, redox potential, and soil temperature (Smith et al., 2008). Carbon dioxide is released in large part due to microbial decay, burning of plant matter, and respiration of both soil organisms and plant roots (Raich and Potter, 1995, Smith et al., 2008). It is also released to a small extent through the chemical oxidation of carbon (C)-containing materials (Lundegårdh, 1927). Soil microorganisms use soluble $\mathrm{C}$ for cell synthesis and energy. This $\mathrm{C}$ is consumed at variable rates depending on the biomass and relative growth rate of the microorganism populations ( $\mathrm{Li}, 1992)$. The difference between this amount of consumed $\mathrm{C}$ and the amount used for cell synthesis equals the production of $\mathrm{CO}_{2}$ from soil microorganisms (Baggs et al., 2003). Soil $\mathrm{CO}_{2}$ emissions vary by season, with maximum emissions occurring during periods of active plant growth (Raich and Potter, 1995). Although $\mathrm{CO}_{2}$ is the major GHG of concern for the total economy, $\mathrm{N}_{2} \mathrm{O}$ is the most important GHG concerning agriculture, mainly from soils and $\mathrm{N}$ inputs to crop systems (Snyder et al., 2009).

Many factors affect $\mathrm{N}_{2} \mathrm{O}$ emissions from fertilized fields. These factors can be grouped into two categories, soil and management factors. Soil factors are temperature, precipitation, soil moisture content, soil oxygen $\left(\mathrm{O}_{2}\right)$ status, soil porosity, freezing and thawing cycles, microorganism abundance and activity, soil organic carbon content (Eichner, 1990), soil texture, soil drainage, abundance of $\mathrm{NO}_{3}-\mathrm{N}$, and soil $\mathrm{pH}$ (Li et al., 1992). Management factors are fertilizer type, fertilizer application, type of crop 
(Akiyama et al., 2004), application technique, tillage system, irrigation, and residual $\mathrm{N}$ and $\mathrm{C}$ from crops and fertilizer (Eichner, 1990). The $\mathrm{N}_{2} \mathrm{O}$ evolving processes of denitrification and nitrification are affected by the specific combination of multiple factors, making it very complex to predict.

Nitrification is the process in which ammonium $\left(\mathrm{NH}_{4}\right)$ is oxidized by autotrophic bacteria into nitrite $\left(\mathrm{NO}_{2}^{-},\right)$a portion of which is then converted into nitrate $\left(\mathrm{NO}_{3}^{-}\right)$ (Brady and Weil, 2010). Nitrate and $\mathrm{NO}_{2}^{-}$, may transform into $\mathrm{N}_{2} \mathrm{O}$ under aerobic conditions (Bremner and Blackmer, 1978). Denitrification of $\mathrm{NO}_{2}{ }^{-}$and $\mathrm{NO}_{3}{ }^{-}$by anaerobic heterotrophic bacteria also results in the release of $\mathrm{N}_{2} \mathrm{O}$ (Follett and Delgado, 2002). Nitrification and denitrification are highly dependent on the nitrifying and denitrifying bacteria. Higher rates of bacterial growth and activity lead to increased emissions of $\mathrm{N}_{2} \mathrm{O}$ (Lesschen et al., 2011).

The issue of mitigating emissions of $\mathrm{CO}_{2}$ and $\mathrm{N}_{2} \mathrm{O}$ may not be limited to managing the two gases separately. A more effective approach would be based on an understanding of the influence of soil and management factors on $\mathrm{C}$ and $\mathrm{N}$ in the soil, and $\mathrm{CO}_{2}$ and $\mathrm{N}_{2} \mathrm{O}$ flux into the atmosphere. Although higher levels of SOM can lead to greater $\mathrm{N}_{2} \mathrm{O}$ emissions (Baggs et al., 2003), they also can lead to sequestration of large stocks of $\mathrm{C}$ in the soil, thereby reducing atmospheric $\mathrm{CO}_{2}$ concentrations (Snyder et al., 2009). Input of $\mathrm{N}$ fertilizer can induce soil $\mathrm{C}$ storage by promoting crop dry matter production and introducing additional C to the soil (Paustian et al., 1992). Vigorous plant growth resulting from greater available $\mathrm{N}$ contributes to $\mathrm{C}$ sequestration and higher levels of soil $\mathrm{C}$ over time. Utilizing effective fertilization and crop rotation techniques can increase crop yields and SOM levels (Snyder et al., 2009). 
Organic agriculture is a rapidly developing enterprise but by nature restricted in the types of fertilizer available for crop production. Synthetic fertilizers are not allowed (AMS, 2014). Instead, many producers use organic-based fertilizers such as manure and compost. Compost can provide macro and micronutrients such as $\mathrm{P}, \mathrm{K}, \mathrm{C}, \mathrm{N}$, and $\mathrm{Fe}$ (Baldwin and Greenfield, 2006; Eghball, 2002). Although compost may initially have high $\mathrm{NO}_{3}{ }^{-}$content, soil amended with compost quickly reaches low levels of $\mathrm{NO}_{3}{ }^{-}$due to net loss through leaching, root uptake, and denitrification (Stamatiadis et al., 1999; Steiner et al., 2007). This is probably why organic fertilizers have been shown to cause lower $\mathrm{N}_{2} \mathrm{O}$ emissions than chemical fertilizers (Akiyama et al., 2004; Bouwman et al., 2002; Lesschen et al., 2011). Nitrous oxide emissions increase as larger amounts of easily mineralizable $\mathrm{N}$, characteristic of conventional $\mathrm{N}$-fertilizer, are applied to the soil (Lesschen et al., 2011; MacKenzie et al., 1997).

The processes of SOM transformations in the soil and $\mathrm{CO}_{2}$ emissions from compost amendments has been described well by Favoino and Hogg (2008). Large fluxes of $\mathrm{CO}_{2}$ are emitted first during the intensive stages of composting, where organic material is broken down by microorganisms. The compost is then left to mature. Once compost is applied to the soil, $\mathrm{CO}_{2}$ emissions eventually decline to stable levels. Amendments of compost also help to reverse declines in SOM. As the stable organic fractions in soil accumulate, $\mathrm{C}$ which might have been emitted as $\mathrm{CO}_{2}$ remains in the soil. If applications of organic inputs continue, rates of additions and losses will eventually equalize, and levels of SOM will reach a steady-state condition. At this point, mineralization balances the accumulation of SOM. The level that this steady-state condition reaches is dependent on factors such as climate and cropping conditions, the annual rate of application of 
organic matter, and the form of organic matter applied. While the overall system is reaching this equilibrium, considerable gains in $\mathrm{C}$ content can be made in the short and medium term, which could have significant potential for reducing $\mathrm{CO}_{2}$ emissions. Because compost is being utilized in this study, minimal emissions of $\mathrm{N}_{2} \mathrm{O}$ and $\mathrm{CO}_{2}$ are expected due to the lower $\mathrm{N}$ release and increases in SOM associated with organic fertilizer. Still, differences in emissions may vary according to the compost rates.

Tillage practice has an inconsistent effect on GHG. Tillage, through its destruction of SOM, can stimulate an increase in greenhouse gases (Antle and Ogle, 2012). Thus conventional tillage (CT) may result in higher GHG emissions than NT (Lemke et al., 1999; Malhi et al., 2006). However a NT system results in large amounts of plant residue remaining on the soil surface. Greater $\mathrm{N}_{2} \mathrm{O}$ emissions can be thus be released through the decomposition of this residue in NT systems than those which utilize tillage (Baggs et al., 2003; Ball et al., 1999; Elmi, 2003; Grandy, 2006; MacKenzie et al., 1997; Robertson et al., 2000; Smith et al., 2008). The higher flux is attributed to greater soil moisture contents observed in NT soils (MacKenzie et al., 1997). Crop residue accumulates on the surface of NT systems which reduces evaporation and increases soil moisture content (Baggs et al., 2003; MacKenzie et al., 1997). Also, NT may increase denitrification activity due to a greater amount of oxidizable $\mathrm{C}$ in the surface soils of NT treatments, increasing microbial activity and production of GHG (Baggs et al., 2003, Staley et al., 1990).

Residue is also left on the surface of the soil when cover crops are utilized. Before planting, cover crops are either mowed or rolled over and the grain crop is sowed directly into the mulch. Several studies have found $\mathrm{N}_{2} \mathrm{O}$ emissions to increase following the 
introduction of cover crop residues (Baggs et al., 2003; Lemke et al., 1999). Although gas flux may be higher in NT or CT, others have found no difference in GHG emissions between the two systems (Marland et al., 2001; Robertson et al., 2000; Smith et al., 2008).

In summary the effect of tillage regiment on GHG emissions varies considerably. Emissions may increase, decrease, or not be affected by tillage. The purpose of this study is to investigate within an organic soybean cropping system the effect of tillage/cover crop practice and compost rate on $\mathrm{N}_{2} \mathrm{O}$ and $\mathrm{CO}_{2}$ emissions over a claypan soil in central Missouri.

\subsection{MATERIALS AND METHODS}

\subsubsection{RESEARCH SITE AND MANAGEMENT}

Research plots were established at the University of Missouri Bradford Research and Extension Farm located southeast of the city of Columbia, Missouri. These plots are located in an organic transition area. All standards of nationally certified organic agriculture were maintained throughout the study. The dominant soil series is a Mexico silt loam (fine, smectite, mesic Vertic Epiaqualf) with slopes of 1-4\%. This series is characterized by deep, poorly drained soils formed in loess over loamy sediments originating from glacial till. There also exists a consistent clayplan horizon in the subsurface soil, and the site is located on an upland location of the Central Claypan Till 
Plains. The depth to the claypan varies on the research site from 15 to $25 \mathrm{~cm}$. The mean annual temperature is 12 degrees $\mathrm{C}$ and mean annual precipitation is 995 millimeters.

A crop rotation was established including both cash crops and cover crops (Figure 2-1). In the rotation winter wheat (Triticum aestivum, Bess variety) was planted in the fall and harvested in the late spring. Buckwheat (Fagopyrum esculentum, variety not stated) was planted during the wheat harvest and grew during the summer. During the second year of the rotation, rye and hairy vetch (Vicia villosa variety not stated) were planted in the fall at approximate seeding rates of $67 \mathrm{~kg} \mathrm{ha}^{-1}$ and $33.5 \mathrm{~kg} \mathrm{ha}^{-1}$ respectively into the buckwheat and grew until spring, whereupon they were destroyed through one of the cover crop destruction techniques, either by mowing or rolling/crimping. Corn (WS2992 from Welter Seed variety) was then planted at a seeding rate of 81,546 seeds ha ${ }^{-1}$ in 76 $\mathrm{cm}$ rows. When it was harvested in the fall, rye was planted at $101 \mathrm{~kg} \mathrm{ha}^{-1}$ for the final year of the rotation. In the spring, the rye was killed and soybean (389F.Y from Blue River Hybrids variety) was planted. When soybean was harvested in the fall, wheat was planted and the rotation cycle repeated.

All cash crops of the rotation were initiated in 2012, although wheat was sown in 2012. This thesis is devoted only to the crop of soybean grown during the 2012 and 2013 seasons.

The study was conducted in a randomized complete block with a split-plot design and four replications (144 total plots). The crop area of soybean was divided into four complete block replications which included every treatment. Each block was 36 x $27 \mathrm{~m}$ in size and was split into three 12 x 9 m main plots (Figures 2-2 and 2-3). Main plots were characterized by one of three tillage/cover crop practices: Tillage without cover 
crop (Till), tillage with cover crop (TillCC), or no-tillage with cover crop (NTCC). Each of these three plots was subsequently divided into four $3 \times 9 \mathrm{~m}$ sub-plots of the split-plot design (Figures 2-2 and 2-3). Each of these was assigned one of four compost rates.

Compost rates were 0 , half the recommended rate $(0.5 \mathrm{RR})$, the recommended rate (RR), and 1.5 times the recommended rate (1.5RR) (Table 2-1). These rates were determined based on soybean phosphorous requirements as recommended by the University of Missouri soil testing lab. The compost was purchased from Central Missouri Poultry Producers in California, $\mathrm{MO}$ and was a composition of turkey manure and bedding materials. The product is certified organic and called Early Bird Compost. Nutrient tests showed an N-P-K ratio of 2.8-1.9-2.2.

Plots were managed each year according to tillage/cover crop practice. The rye in the NTCC plots was destroyed differently than the rye in the TillCC plots (Table 2-2). It was mowed in the TillCC plots to make tillage possible, while it was rolled in the NTCC plots. Rolling the rye instead of mowing was done to provide a residue blanket for weed suppression and water conservation.

The soybean used in this study was planted in $76 \mathrm{~cm}$ rows. Soybean was irrigated five times during 2012 with $2.5 \mathrm{~cm}$ of water applied at each irrigation event (Table 2-2). This was done because the 2012 growing season was exceptionally dry (Figure 2-4) and hot (Figure 2-5) when compared to 30 year averages. Irrigation was deemed necessary to provide the soybean crop with enough water for survival and grain production. Soybean was planted at the $2 \mathrm{~cm}$ depth at 156,800 seeds ha ${ }^{-1}$ using a no-till four-row John Deere 7100 cone planter. Soybean was harvested at physiological maturity using a Wintersteiger small plot combine. 
No irrigation was applied during 2013. Although above average precipitation fell in the spring, the summer was drier than average (Figure 2-4). Precipitation and growing degree data was taken from the Columbia Regional Airport Weather Station.

\title{
2.3.2 GREENHOUSE GAS SAMPLING, PROCESSING, AND
}

\begin{abstract}
ANALYSIS
All GHG measurements closely followed USDA-ARS GRACEnet (Greenhouse Gas Reduction through Agricultural Carbon Enhancement network) protocol (Parkin et al., 2003). The GRACEnet research program was initiated by USDA-ARS with the objective to "identify and further develop agricultural practices that will enhance $\mathrm{C}$ sequestration in soils, promote sustainability and provide a sound scientific basis for $\mathrm{C}$ credits and trading programs." The program also focuses on quantifying $\mathrm{N}_{2} \mathrm{O}$ emissions associated with agriculture. To support its objective, GRACEnet developed a "chamberbased trace gas flux measurement" protocol to accurately record GHG emissions in the field. The general outline of the procedure used during this study which followed this protocol is outlined below.
\end{abstract}

The chambers used to capture GHG were made from buffet warming trays (Images 2-1 and 2-2) (Parkin et al., 2003). A septum was fitted into a hold drilled through the bottom of the tray where gas could be extracted by a needle. The chambers were insulated to prevent internal temperature changes during sampling. Four plastic tubes were connected to the septum on the inside of the chamber (Image 2-2). These tubes were 
open to the four corners of the chamber, to ensure representative gas sampling. A short copper pipe was inserted into the side of the chamber to prevent pressure from forming inside the chamber (Image 2-2).

The chamber was deployed in the field upside-down to create an enclosure over the soil (Image 2-1). A tight seal was formed by clamping the chamber onto an anchor which had been installed in the soil. These anchors were made of the outer rim of additional food warming trays with the bottoms cut off. The end which is cut was driven into the soil, and the rim of the anchoring tray aligned with the rim of the chamber tray. Clamps were used to keep these trays sealed together during sampling events. The anchors were fixed into the soil by placing wooden slats on their outer rims and using a wooden mallet to pound the anchor, cut side first, into the soil (Images 2-3 and 2-4). The anchors were only removed from the soil during harvesting and cultivation events. Chambers were stored in a lab and brought to the field when gas samples were taken.

One of the chambers was installed with an attached thermometer which measured the temperature inside the chamber. Chamber temperature was noted during sampling.

Gas samples were taken through the use of a $5 \mathrm{~mL}$ plastic syringe and needle. Before drawing of gas sample from the chamber, $10 \mathrm{~mL}$ of air were extracted from the chamber and released into the ambient air. This was done to ensure that the gas sample taken did not include the air in the plastic tubing which was connected to the septum. The gas sample was then drawn through the chamber's septum and injected into a previously vacuumed $4 \mathrm{~mL}$ glass Fisherbrand vial.

Soil temperatures were taken using a digital thermometer at the $8 \mathrm{~cm}$ depth. The thermometer was placed directly into the soil next to the chamber. Soil samples were 
removed up to the $5 \mathrm{~cm}$ depth in each plot during sampling events and tested for moisture content on a gravimetric weight basis. They were weighed immediately after sampling and then again after being dried in an oven at $107^{\circ} \mathrm{C}$ for 24 hours.

Ambient air temperature was taken at each sampling event with a simple thermometer.

In order to complete gas sampling within a reasonable time, not all treatments were sampled. The plots tested during this experiment included those with compost rates of 0 , the RR, and $1.5 \mathrm{RR}$ at all tillage/cover crop treatments. The sampling procedure consisted of several steps:

1. During a sampling event, all chambers were brought to the field and placed next to an installed anchor.

2. Gas samples were then taken three times over the course of an hour.

a. The first sample was taken at Time 0 , immediately after the chamber was clamped to the anchor.

b. The second sample was taken at Time 1, 30 minutes after the first sample.

c. The final sample was taken at Time 2, 60 minutes after the first sample.

3. Soil temperature was measured in each plot every time a gas sample was taken. Air and chamber temperature was recorded at three times: at the beginning of Time 0 , Time 1, and Time 2. Three soil samples were removed at the $5 \mathrm{~cm}$ depth in each plot immediately next to the chamber. These samples were mixed together to ensure representative sampling for soil moisture content. 
Gas sampling occurred according to certain external events, in an attempt to capture periods of maximum gas flux. These events included precipitation or irrigation over 0.64 $\mathrm{cm}$, planting, and cultivation. Sampling occurred at three times after these events: at one day, three days, and seven days following the event. During the 2012 growing season, gases were sampled 14 times. Gases were sampled 12 times during the 2013 growing season. Gas samples were immediately taken to the lab and processed as soon as possible using gas chromatography.

Sample processing and analysis was accomplished through four steps:

1. All samples were processed using a Fisher Scientific 910 gas chromatograph (GC).

a. Gases were processed in batches of 45 or 46 samples. Two sets of gas standards were used (Table 2-3). The standards were run before each batch of samples. A Cobra autosampler was used for automated and consistent injection into the GC. The autosampler used to process the gases had a capacity of 50 samples, so a new set of standards were used for every 45 or 46 samples. All $\mathrm{CO}_{2}$ samples were processed with a flame ionization detector (FID), while $\mathrm{N}_{2} \mathrm{O}$ samples were processed with a thermal conductivity detector (TCD).

b. The software program PeakSimple 420 was connected to the GC. The program recorded peak areas of each sample according to their concentrations of $\mathrm{CO}_{2}$ and $\mathrm{N}_{2} \mathrm{O}$.

2. The concentration of gases was determined in ppm. 
a. The peak areas for each standard and the actual ppm of the standard were used to create a regression equation. This regression equation was used to determine the ppm of $\mathrm{CO}_{2}$ and $\mathrm{N}_{2} \mathrm{O}$ of each sample from their peak areas.

3. Gas fluxes were calculated.

a. Samples now recorded in ppm of $\mathrm{CO}_{2}$ and $\mathrm{N}_{2} \mathrm{O}$ were converted into $\mu \mathrm{L}$ $\mathrm{N}_{2} \mathrm{O}$ Liter $^{-1} h^{-1}$ and $\mu \mathrm{LCO}_{2}$ Liter $^{-1} h^{-1}$ by the equation derived by Hutchinson and Mosier (1981):

$(\mathrm{C} 1-\mathrm{C} 0)^{2} /[\mathrm{t} 1 \times(2 \times \mathrm{C} 1-\mathrm{C} 2-\mathrm{C} 0)] \times \ln [(\mathrm{C} 1-\mathrm{C} 0) /(\mathrm{C} 2-\mathrm{C} 1)]$ where $\mathrm{C} 0, \mathrm{C} 1$, and $\mathrm{C} 2$ are the chamber headspace gas concentrations in ppm at time 0,1 , and 2 , respectively, and $\mathrm{t} 1$ is the interval between gas sampling points in hours, which was 0.5 during our sampling procedure.

b. Three samples were taken in each plot over the course of an hour (the first at time 0,30 minutes later at time 1 , and 60 minutes from the first sample at time 2). For a positive flux to have occurred, the gas concentration of each succeeding sample needed to be greater than the one preceding it. So a flux was only recorded if the gas concentration at Time 2> Time 1> Time 0 . If this condition did not occur, than the gas flux was recorded as 0.

4. A seasonal gas emissions value was calculated from individual sampling fluxes.

a. Units of $\mu \mathrm{L} \mathrm{N}_{2} \mathrm{O}$ Liter $^{-1} \mathrm{~h}^{-1}$ and $\mu \mathrm{L} \mathrm{CO}_{2}$ Liter $^{-1} \mathrm{~h}^{-1}$ were further converted to $\mu \mathrm{g} \mathrm{N} \mathrm{m}{ }^{2} h^{-1}$ and $\mu \mathrm{g} \mathrm{C} \mathrm{m}^{2} \mathrm{~h}^{-1}$. 
b. Gaps in sampling existed throughout the season, as emissions were not constantly being measured. To estimate the flux of gas which existed between sampling dates, the emissions sampled at the beginning and end of a gap were averaged. These estimated fluxes, along with all measured fluxes, were converted from $\mu \mathrm{g} \mathrm{N} \mathrm{m}{ }^{2} \mathrm{~h}^{-1}$ and $\mu \mathrm{g} \mathrm{C} \mathrm{m}{ }^{2} \mathrm{~h}^{-1}$ to the total seasonal flux recorded in $\mathrm{kg} \mathrm{N}_{2} \mathrm{O}-\mathrm{N} \mathrm{ha}^{-1}$ and $\mathrm{kg} \mathrm{CO}_{2}-\mathrm{C} \mathrm{ha}^{-1}$.

There exists the possibility that $\mathrm{N}_{2} \mathrm{O}$ or $\mathrm{CO}_{2}$ can accumulate in their respective detector channels. It is obvious when this occurs because the resulting peak area is on a scale much higher than other samples. This occurred in two instances for $\mathrm{N}_{2} \mathrm{O}$ during our analyses of the samples obtained on $6 / 21 / 2013$. The two fluxes were regarded as outliers and excluded from the results.

Data from GHG emissions was analyzed using the General Linear Models procedure in SAS (Version 9.2, SAS Institute Inc., Cary, NC). Due to substantially positive skewness of the GHG emissions data, analysis of variance was calculated based on a $\log 10$ transformation. When significant $(\mathrm{P} \leq 0.05)$ treatment effects were found with F-tests, means comparisons were performed using least significant differences (LSD).

\subsection{RESULTS AND DISCUSSION}

Neither tillage/cover practice nor compost was found to affect either season-long accumulative $\mathrm{N}_{2} \mathrm{O}$ or $\mathrm{CO}_{2}$ emissions during the 2012 or 2013 growing season (Tables 2-4 -2-6). Emissions of both gases over both seasons are shown as affected by tillage/cover 
crop practice and compost rate (Figures 2-6 - 2-9). Three individual sampling dates which showed above average $\mathrm{N}_{2} \mathrm{O}$ flux in 2012 and 2013 were also analyzed to test for differences in emissions between management treatments, however no significant relationships were found for these events (Tables 2-7 and 2-8). High variability between replications within the study prevented the formation of significant relationships. It suggests local microenvironment factors not measured were more important to contrast GHG emissions than study treatments.

Based on what others have documented these results showing generally low levels of GHG emissions are not completely unexpected. The year 2012 was characterized by an extreme drought, with precipitation much lower than average (Figure 2-4). The summer of 2013 also was drier than normal, although not as dry as 2012. A lack of precipitation would have severely limited soil moisture content. Low soil moisture content hinders production of both $\mathrm{N}_{2} \mathrm{O}$ and $\mathrm{CO}_{2}$ (Akiyama et al., 2004; MacKenzie et al., 1997). It is also possible that denitrification may have occurred in large part all the way to $\mathrm{N}_{2}$ on the clayey soils, thereby limiting $\mathrm{N}_{2} \mathrm{O}$ production. Indeed, the emission values found during this investigation were much lower than those found in other studies which documented $\mathrm{CO}_{2}$ and $\mathrm{N}_{2} \mathrm{O}$ on agriculture soils (Table 2-9) (Curtin et al., 2000; Drury et al., 2006; Parkin and Kaspar, 2006) including studies performed on claypan soils in the same region (Bailey et al., 2009). The fact that emissions were low may have limited the development of any potential relationships between management treatments and GHG emissions.

The composted poultry litter contributed little to GHG emissions in this investigation. Fertilizer in general tends to increase $\mathrm{N}_{2} \mathrm{O}$ emissions as large amounts of 
mineral $\mathrm{N}$ are introduced to the soil (Lesschen et al., 2011; MacKenzie et al., 1997). However soils treated with organic fertilizers have been shown to have lower $\mathrm{N}_{2} \mathrm{O}$ emissions than those treated with chemical fertilizers (Akiyama et al., 2004; Lesschen et al., 2011). Low precipitation during 2012, and a dry summer in 2013 (Figure 2-4) may have hindered both mineralization and denitrification of the $\mathrm{NO}_{3}{ }^{-}$derived from the compost, thus limiting $\mathrm{N}_{2} \mathrm{O}$ production. Dry conditions may also have buffered microbial decomposition of $\mathrm{C}$ in the compost and cover crop and thereby limited $\mathrm{CO}_{2}$ emissions. The low emission levels associated with compost may have prevented a significant relationship from appearing related to GHG emissions during this study.

Other types of compost may have a significant influence on GHG emissions. The compost used in this study was a blend of turkey litter, from a local source. Composition of organic compost varies considerably. More research is necessary to determine the impact of compost rate on GHG emissions for organic soybean as well as other crops.

Another possible explanation for the lack of detecting a management effect on GHG emissions is that sampling may not have been sufficiently frequent. Fluxes in gases which might have contributed to the discovery of relationships between management treatments and GHG emissions may have occurred outside of actual sampling measurements. This issue could only be resolved with greater sampling frequency and temporal proximity to periods of maximum gas flux. Static sampling chambers which remain in the field throughout the growing season and continually collect gas emissions would also resolve the issue of failing to take measurements during potentially significant gas fluxes (Healy et al., 1996). 
Although the possibility exists that emissions were too low for measureable relationships to have formed, similar studies have found no effect of tillage practice on GHG emissions (Marland et al., 2001; Robertson et al., 2000; Smith et al., 2008). Other studies have found emissions to increase or decrease with tillage. It would seem that there is not a consistent effect of tillage on GHG emissions which is common to all environmental conditions, likely due to variations in soil, climate, and vegetation.

\subsection{CONCLUSION}

Greenhouse gas emissions from agricultural soils can be of important environmental and economic significance. They contribute to the steady increase in atmospheric concentrations of GHG, which may result in changes in the planet's climate. Also, carbon credit programs may become more widespread in the future. Growers utilizing management techniques associated with low GHG emissions may benefit from these regulatory programs. Emissions of $\mathrm{N}_{2} \mathrm{O}$ and $\mathrm{CO}_{2}$, two important $\mathrm{GHG}$ studied in this thesis, may indicate losses of soil $\mathrm{N}$ and $\mathrm{C}$. Mitigating emissions of these gases would help prevent changes to the atmosphere and preserve $\mathrm{N}$ and $\mathrm{C}$ stocks in soils.

Management of organic agriculture often includes growing techniques such as cover cropping and compost. The effect of these management techniques on GHG emissions is not well understood. The results of this investigation were that soil emissions of $\mathrm{N}_{2} \mathrm{O}$ and $\mathrm{CO}_{2}$ were relatively low compared to other similar studies, and not affected by tillage/cover crop practice or compost rate. 
The lack of a relationship between GHG emissions and management treatments may be related to the environmental conditions which limited gas flux to low levels during this investigation. These conditions included a severe lack of precipitation in 2012. Relationships may occur under different environmental conditions and management techniques. Also, sampling frequency may not have captured flux measurements which would have led to differences between treatments. Still, other studies have also found no relationship between tillage and GHG emissions, so the results of this study are not without precedent.

Research related to $\mathrm{N}_{2} \mathrm{O}$ and $\mathrm{CO}_{2}$ emissions on agriculture soils requires constant attention and improvement. Monitoring the gaseous loss of these nutrients, and comparing losses to management strategies, will lead to a better understanding of how to keep these nutrients in the soil and limit GHG emissions on agriculture land.

Additional research is necessary to determine the relationship between $\mathrm{CO}_{2}$ and $\mathrm{N}_{2} \mathrm{O}$ emissions and tillage/cover crop practice or compost rate. Research needs to include a variety of cover crops, compost types, and environmental conditions to generate a sufficiently large pool of information related to GHG emissions as they relate to organic agriculture management techniques. 


\subsection{TABLES, FIGURES, AND IMAGES}

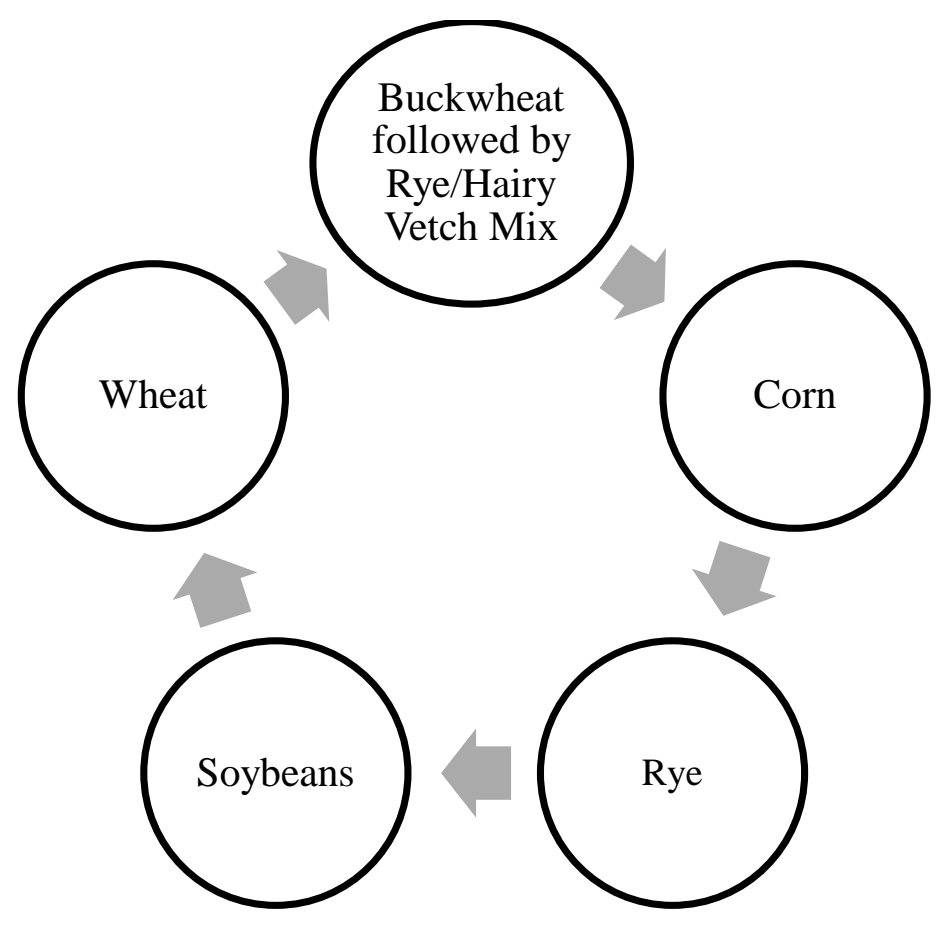

Figure 2-1. Crop rotation followed during this study. 


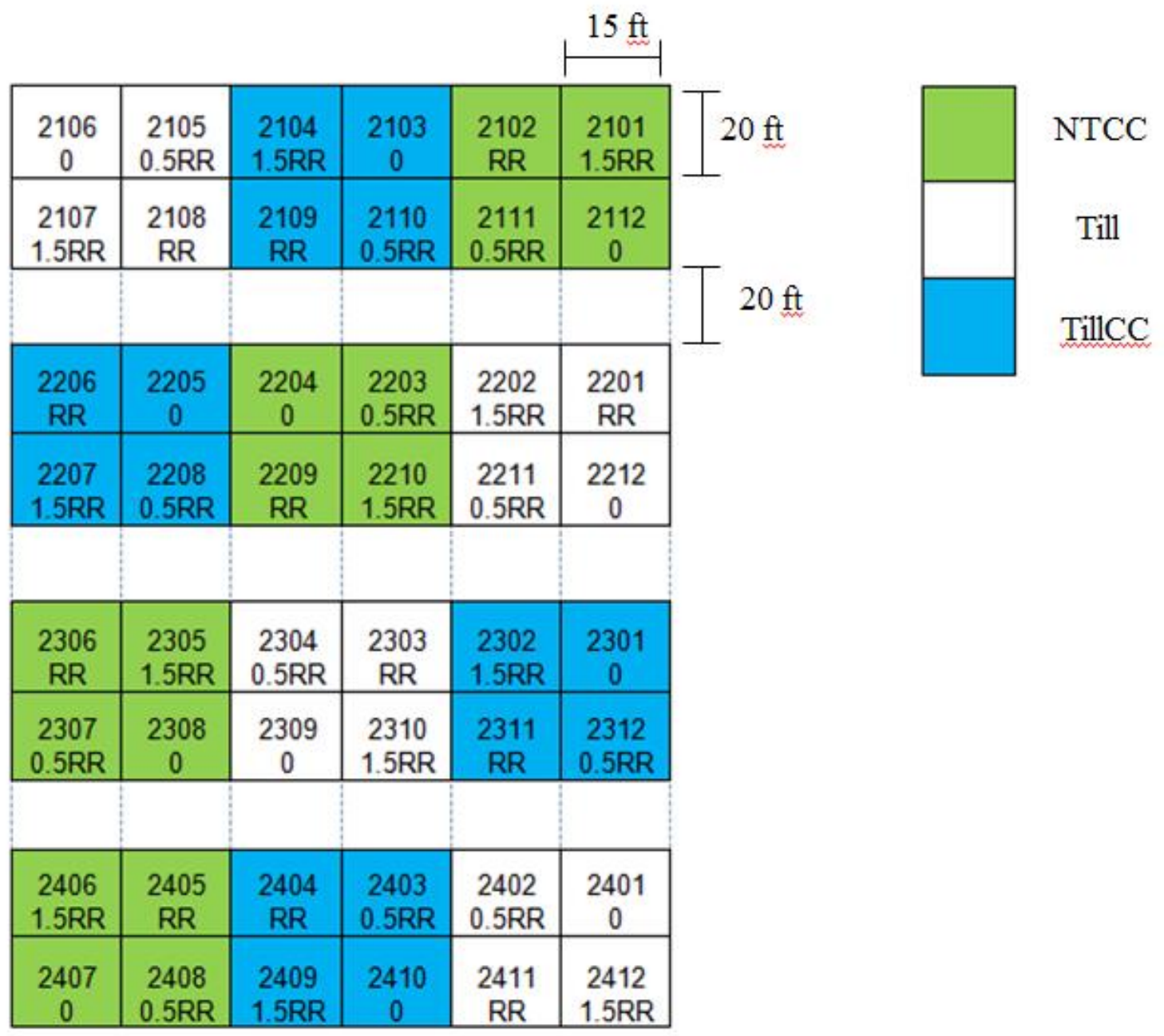

Figure 2-2. Research plot plan for 2012. NTCC: No-till cover crop, Till: Tilled without cover crop, TillCC: Tilled with cover crop. 0.5RR: Half the recommended compost rate, RR: The recommended compost rate, 1.5RR: One and a half times the recommended compost rate. 


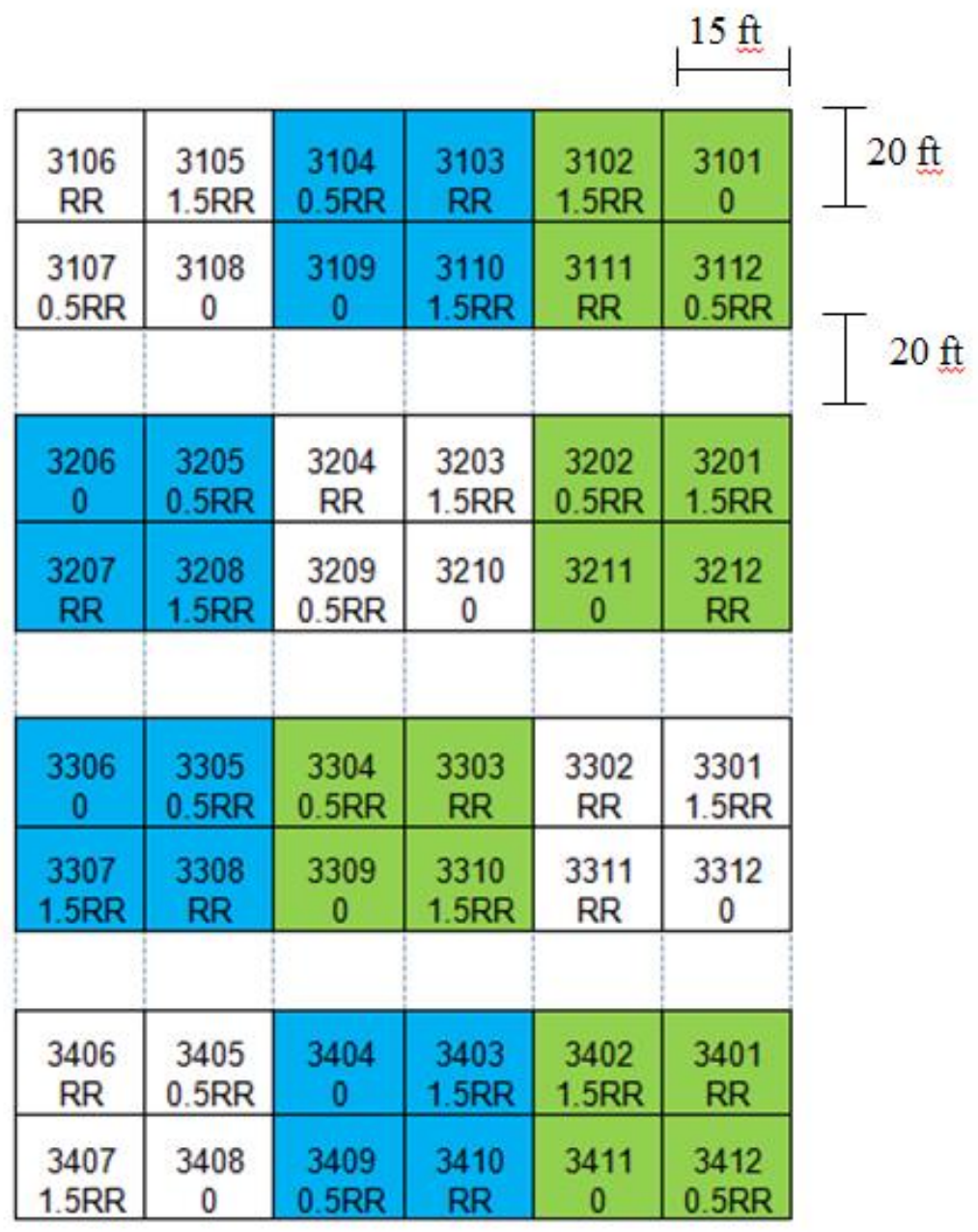

NTCC

Till

TillCC

Figure 2-3. Research plot plan for 2013. NTCC: No-till cover crop, Till: Tilled without cover crop, TillCC: Tilled with cover crop. 0.5RR: Half the recommended compost rate, RR: The recommended compost rate, 1.5RR: One and a half times the recommended compost rate.

Table 2-1. Compost rates during the 2012 and 2013 growing seasons of this study.

\begin{tabular}{cccc}
\hline Compost Rate & kg/ha applied & kg/ha P & kg/ha N \\
\hline 0 & 0 & 0 & 0 \\
$0.5 \mathrm{RR}$ & 2654 & 50 & 73 \\
RR & 5309 & 100 & 147 \\
$1.5 \mathrm{RR}$ & 7963 & 151 & 221 \\
\hline
\end{tabular}


Table 2-2. Management techniques and dates utilized during this investigation. TCCP: Tillage/cover crop practice. NTCC: No-till cover crop, Till: Tilled without cover crop, TillCC: Tilled with cover crop. N/A: Not applicable.

\begin{tabular}{|c|c|c|c|c|c|c|c|c|}
\hline Year & TCCP & $\begin{array}{c}\text { Rye } \\
\text { planted }\end{array}$ & Rye destruction & $\begin{array}{c}\text { Compost } \\
\text { applied }\end{array}$ & $\begin{array}{c}\text { Irrigation } \\
\text { applied }\end{array}$ & Tillage & $\begin{array}{c}\text { Soybean } \\
\text { planted }\end{array}$ & Harvest \\
\hline \multirow{3}{*}{2012} & NTCC & & Roller crimper 5/29 & \multirow{3}{*}{$5 / 29$} & $6 / 5$ & N/A & \multirow{3}{*}{$5 / 29$} & \multirow{3}{*}{$10 / 17$} \\
\hline & TillCC & $10 / 8 / 2011$ & Flail mower 5/29 & & $\begin{array}{c}7 / 5 \\
7 / 19 \\
8 / 2\end{array}$ & $\begin{array}{l}5 / 29 \\
6 / 21\end{array}$ & & \\
\hline & Till & & N/A & & $8 / 16$ & & & \\
\hline \multirow[t]{3}{*}{2013} & NTCC & \multirow[b]{2}{*}{$10 / 19 / 2012$} & Roller crimper $6 / 11$ & \multirow{3}{*}{$6 / 11$} & \multirow{3}{*}{ N/A } & N/A & \multirow{3}{*}{$6 / 12$} & \multirow{3}{*}{$10 / 14$} \\
\hline & TillCC & & Flail mower $6 / 11$ & & & $\begin{array}{l}6 / 11 \\
7 / 11\end{array}$ & & \\
\hline & Till & & N/A & & & & & \\
\hline
\end{tabular}




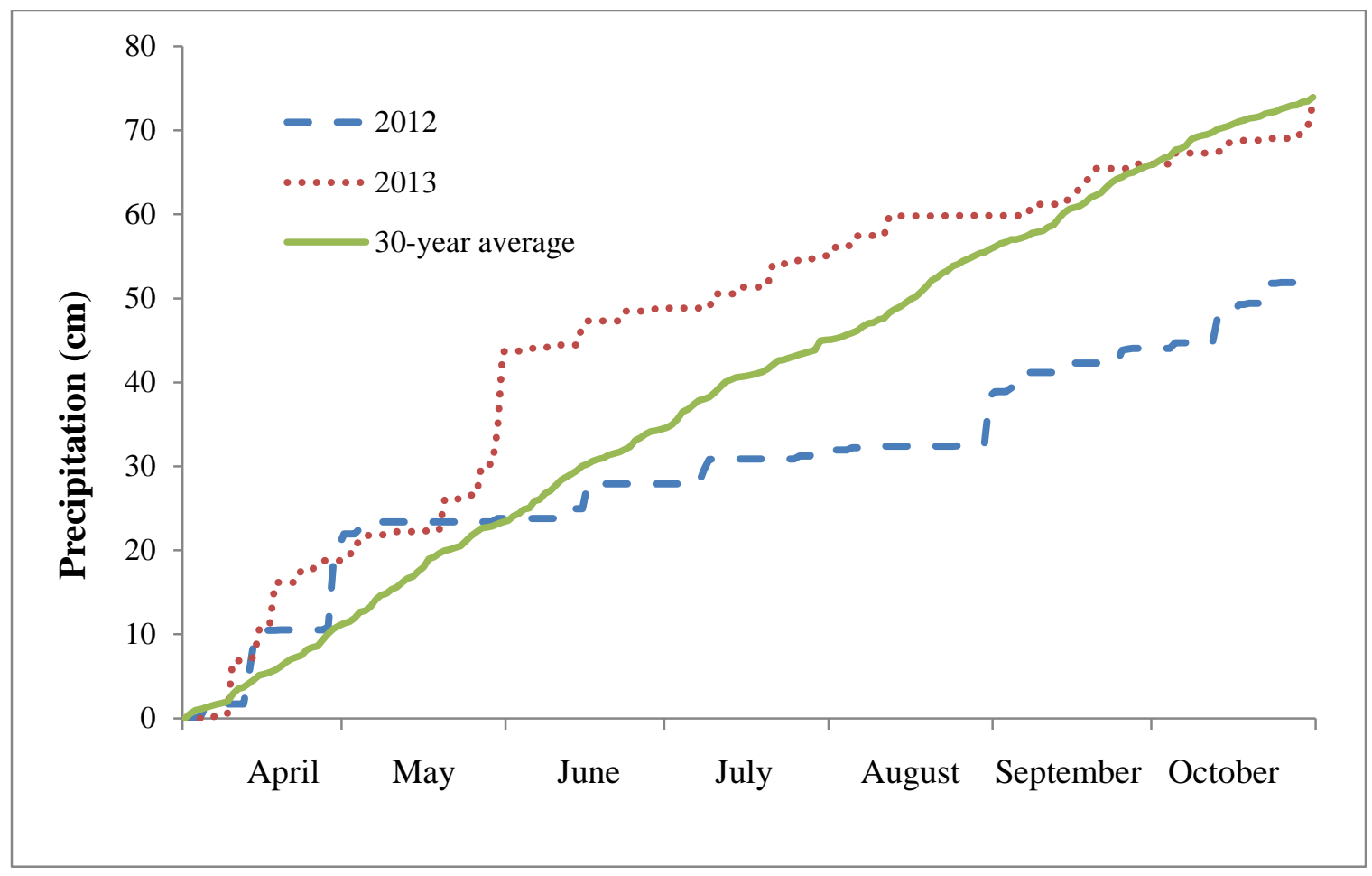

Figure 2-4. Precipitation (cm) for the months of April - October during 2012, 2013, and the 30 year average.

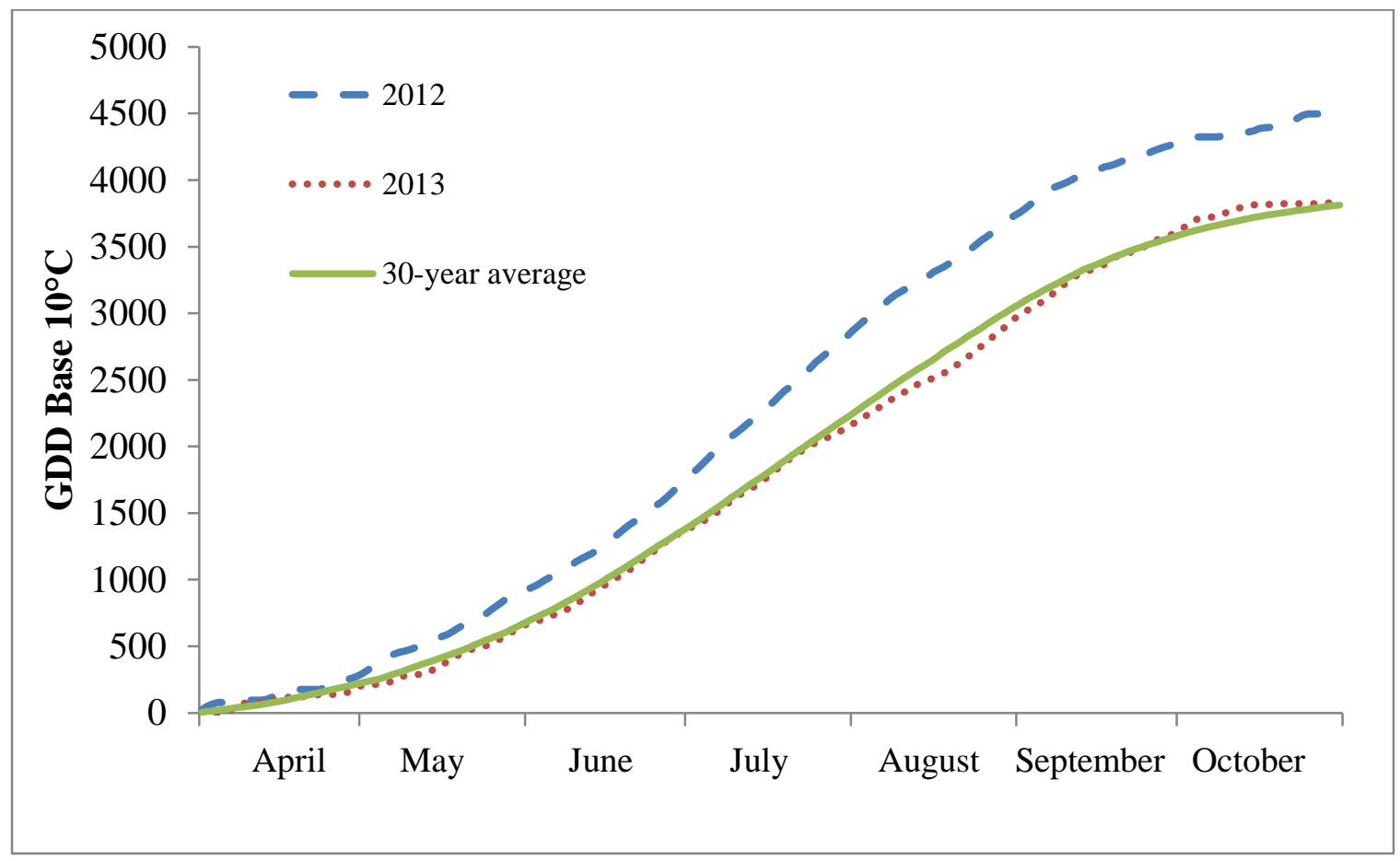

Figure 2-5. Growing degree days (GDD) base $10^{\circ} \mathrm{C}$ for the months of April - October during 2012, 2013, and the 30 year average. 


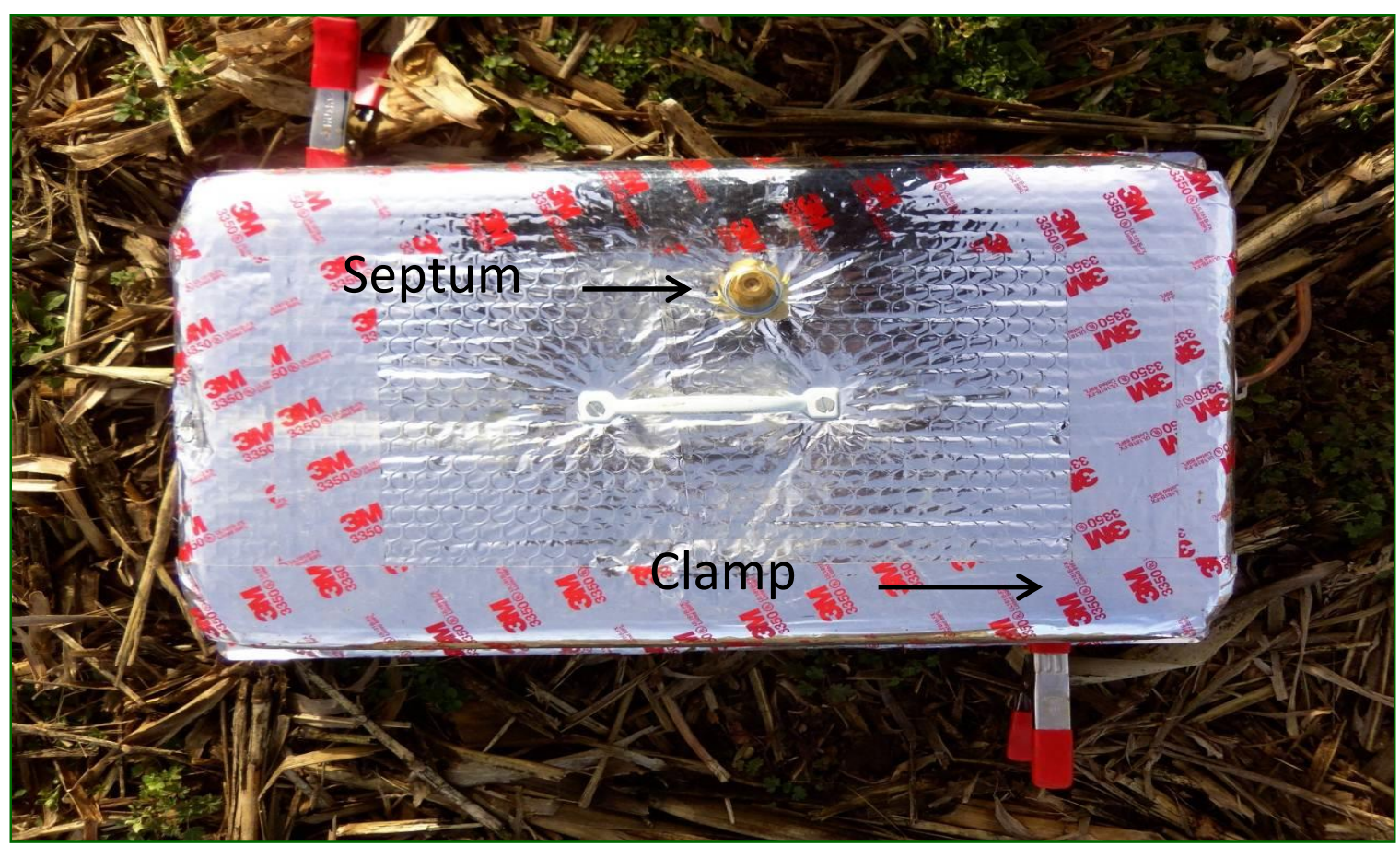

Image 2-1. Chamber used to collect GHG emissions, viewed from the outside.

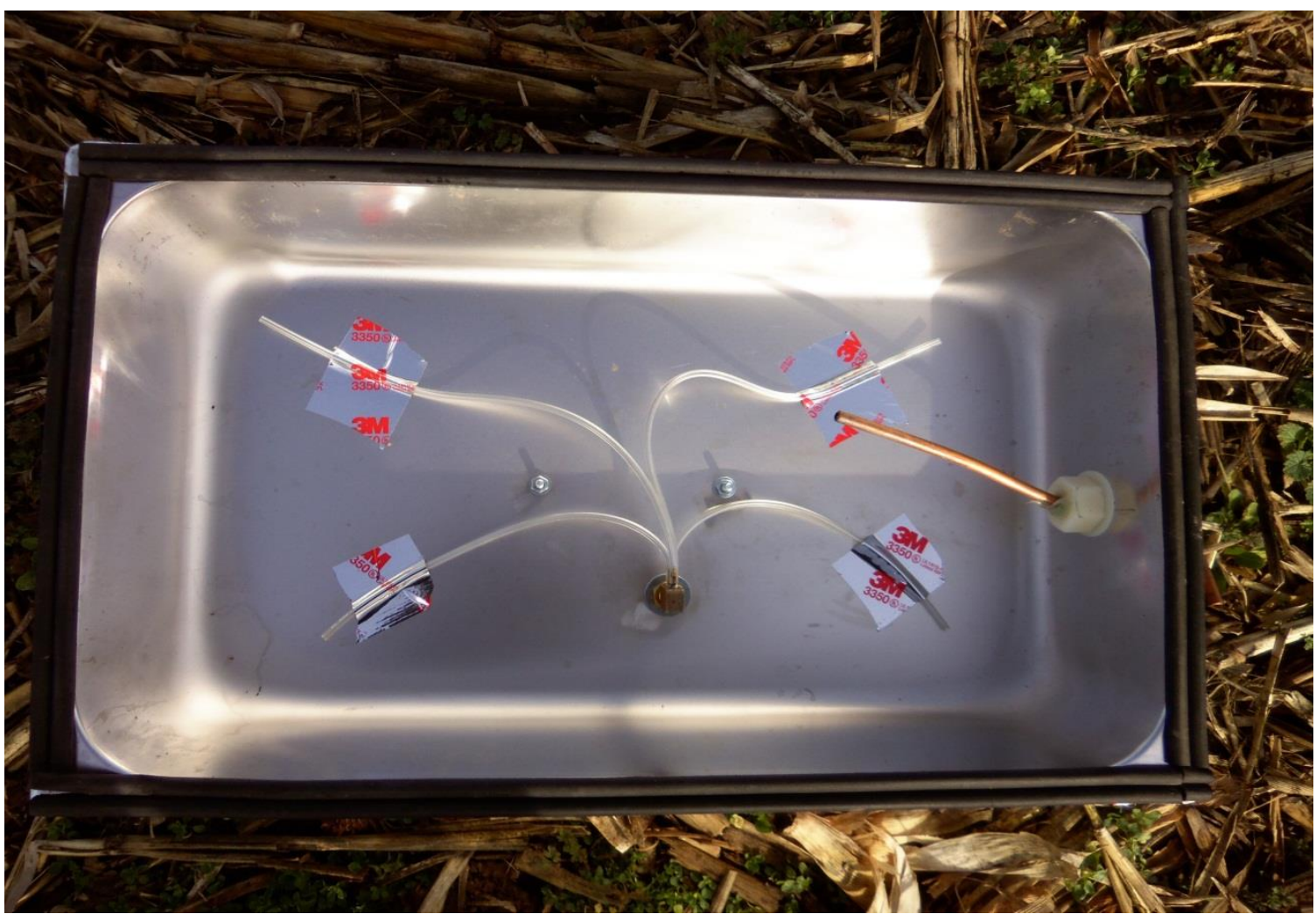

Image 2-2. Chamber used to collect GHG emissions, viewed from the inside. 


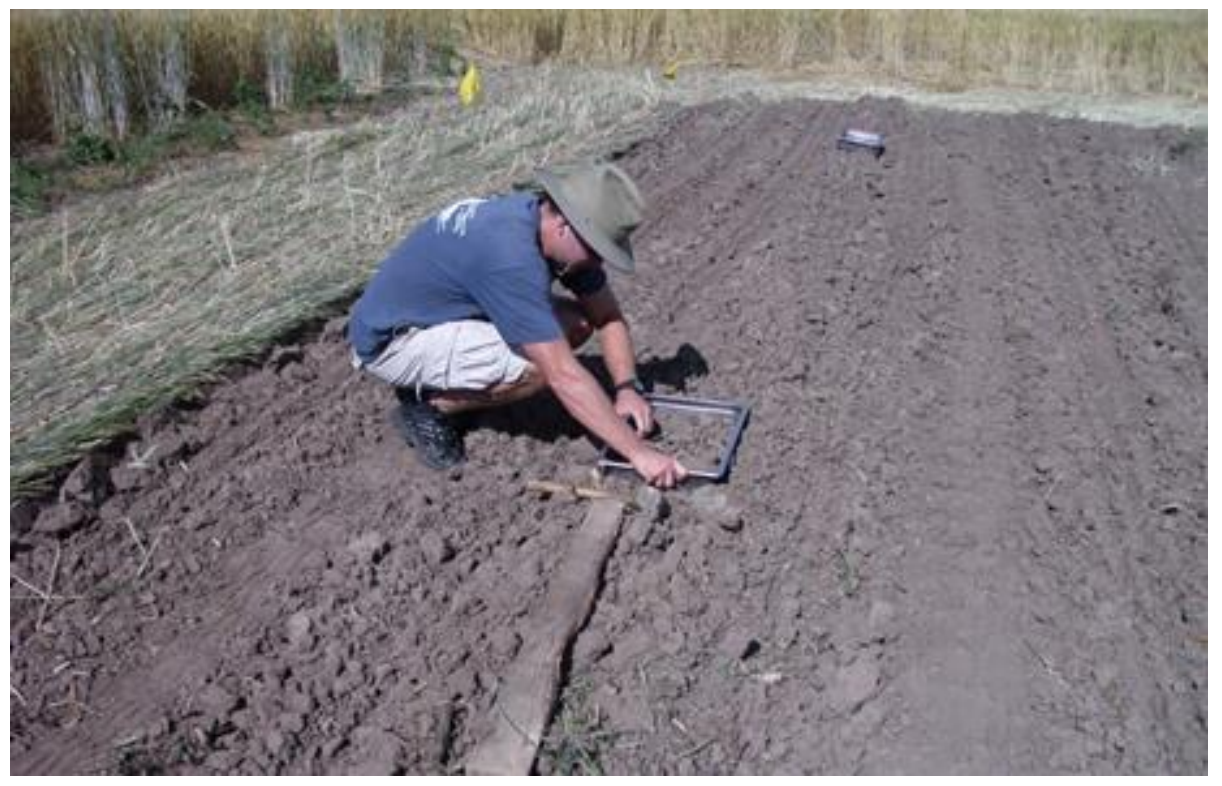

Image 2-3. Installing anchors into a Till plot in May 2012.

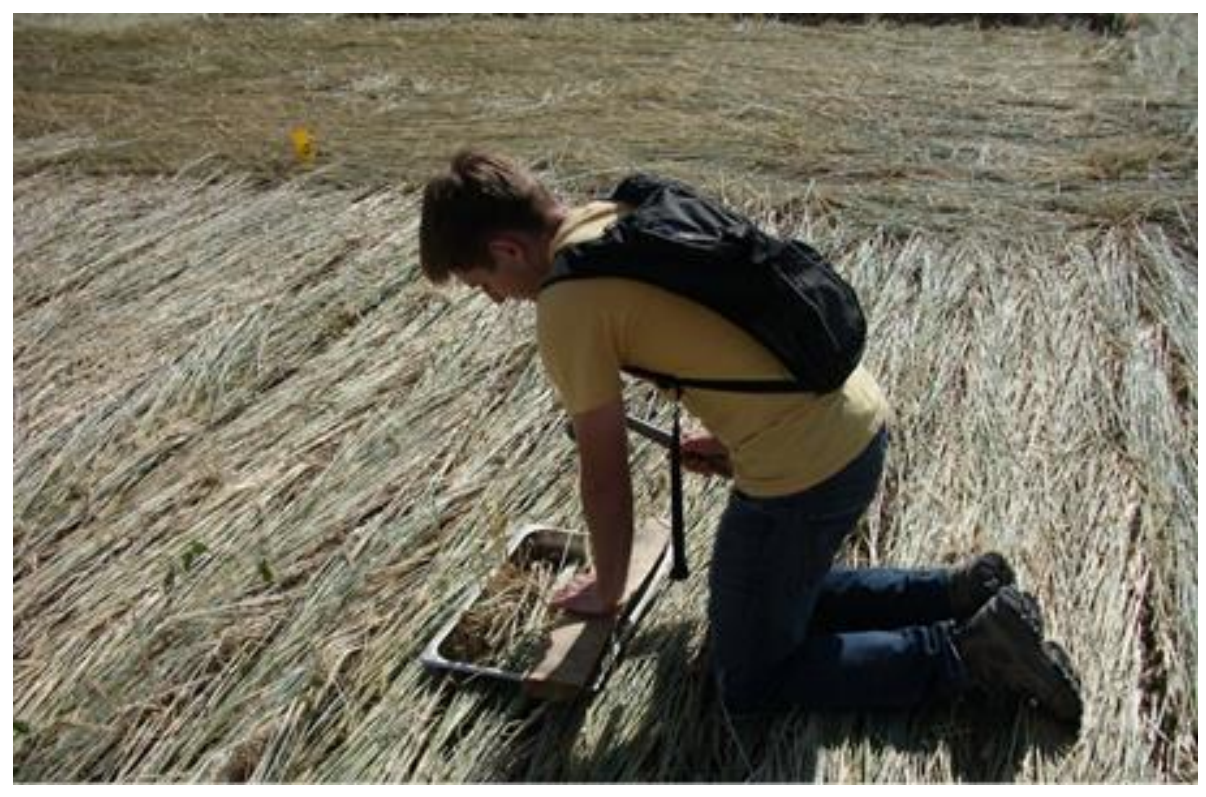

Image 2-4. Installing anchors into a NTCC plot in May 2012. 
Table 2-3. Standards of $\mathrm{CO}_{2}$ and $\mathrm{N}_{2} \mathrm{O}$ in ppm used during processing of samples. Two sets of standards were used.

\begin{tabular}{ccc}
\hline & Before 8/13/13 & After $\mathbf{8 / \mathbf { 1 3 } / \mathbf { 1 3 }}$ \\
\hline & 200 & 100 \\
& 500 & 400 \\
$\mathrm{CO}_{2}$ & 1000 & 700 \\
$(\mathrm{ppm})$ & 1500 & 1000 \\
& - & 1500 \\
\hline & 1 & 1 \\
& 10 & 5 \\
$\mathrm{~N}_{2} \mathrm{O}$ & 20 & 10 \\
$(\mathrm{ppm})$ & 50 & 20 \\
& - & 50 \\
\hline
\end{tabular}


Table 2-4. Results of analysis of variance according to tillage/cover crop practice (TCCP) and compost treatments on $\mathrm{CO}_{2}$ emissions under an organic soybean cropping system. Results reflect the 2012 and $2013 \log$ transformed seasonal fluxes.

\begin{tabular}{llccccc}
\hline \multicolumn{6}{c}{$\mathrm{CO}_{2}$ Emissions $\left[\log \left(\mathrm{kg} \mathrm{CO}_{2}-\mathrm{C} \mathrm{ha}^{-1}+1\right)\right]$} \\
\hline Year & Measurement & df & Mean Square & Error & F Value & P-value \\
2012 & TCCP & 2 & 17.16 & 6 & 1.25 & 0.35 \\
& Compost & 2 & 5.08 & 18 & 0.30 & 0.74 \\
& TCCP x Compost & 4 & 8.19 & 18 & 0.48 & 0.75 \\
& TCCP & 2 & 20.99 & 6 & 1.55 & 0.29 \\
& Compost & 2 & 6.00 & 18 & 0.64 & 0.54 \\
& TCCP x Compost & 4 & 10.60 & 18 & 1.13 & 0.37 \\
\hline
\end{tabular}

Table 2-5. Results of analysis of variance according to tillage/cover crop practice (TCCP) and compost treatments on $\mathrm{N}_{2} \mathrm{O}$ emissions under an organic soybean cropping system. Results reflect the 2012 and 2013 seasonal fluxes.

\begin{tabular}{llccccc}
\hline \multicolumn{5}{c}{$\mathbf{N}_{2} \mathbf{O}$ Emissions $\left[\log \left(\mathrm{kg} \mathrm{N}_{2} \mathrm{O}-\mathrm{N} \mathrm{ha}{ }^{-1}+1\right)\right.$} \\
\hline Year & Measurement & df & Mean Square & Error & F Value & P-value \\
2012 & TCCP & 2 & $8.75 \times 10^{-7}$ & 6 & 0.13 & 0.88 \\
& Compost & 2 & $2.16 \times 10^{-6}$ & 18 & 0.67 & 0.52 \\
& TCCP x Compost & 4 & $3.48 \times 10^{-6}$ & 18 & 1.08 & 0.30 \\
& TCCP & 2 & 0.045 & 6 & 1.05 & 0.41 \\
& Compost & 2 & 0.035 & 18 & 0.34 & 0.71 \\
& TCCP x Compost & 4 & 0.156 & 18 & 1.55 & 0.23 \\
\hline
\end{tabular}


Table 2-6. Effects of tillage/cover crop practice (TCCP) and compost treatments on $\mathrm{CO}_{2}$ and $\mathrm{N}_{2} \mathrm{O}$ emissions of an organic soybean cropping system by year. Results reflect the 2012 and 2013 seasonal fluxes.

\begin{tabular}{|c|c|c|c|c|c|}
\hline & & \multicolumn{2}{|c|}{$\mathrm{CO}_{2}$ Emissions } & \multicolumn{2}{|c|}{$\mathrm{N}_{2} \mathrm{O}$ Emissions } \\
\hline & & 2012 & 2013 & 2012 & 2013 \\
\hline \multicolumn{2}{|l|}{ TCCP } & \multicolumn{2}{|c|}{---kg $\mathrm{CO}_{2}-\mathrm{C} \mathrm{ha}^{-1}---$} & \multicolumn{2}{|c|}{---kg N $2 \mathrm{O}-\mathrm{N} \mathrm{ha}^{-1}---$} \\
\hline NTCC & & 162 & 1040 & 0.0011 & 1.04 \\
\hline TillCC & & 188 & 1183 & 0.0022 & 0.41 \\
\hline Till & & 699 & 762 & 0.0022 & 0.14 \\
\hline \multicolumn{6}{|c|}{ Compost } \\
\hline 0 & & 419 & 1094 & 0.0007 & 0.42 \\
\hline $\mathrm{RR}$ & & 376 & 792 & 0.0025 & 1.02 \\
\hline $1.5 \mathrm{RR}$ & & 255 & 1099 & 0.0023 & 0.15 \\
\hline \multicolumn{6}{|c|}{ TCCP x Compost } \\
\hline NTCC & 0 & 245 & 1037 & 0.00010 & 0.059 \\
\hline NTCC & $\mathrm{RR}$ & 99 & 1027 & 0.00332 & 2.991 \\
\hline NTCC & $1.5 \mathrm{RR}$ & 144 & 1056 & 0.00000 & 0.077 \\
\hline TillCC & 0 & 148 & 1188 & 0.00118 & 1.138 \\
\hline TillCC & $\mathrm{RR}$ & 257 & 1020 & 0.00364 & 0.061 \\
\hline TillCC & $1.5 \mathrm{RR}$ & 157 & 1340 & 0.00193 & 0.031 \\
\hline Till & 0 & 864 & 1057 & 0.00090 & 0.054 \\
\hline Till & RR & 770 & 329 & 0.00042 & 0.009 \\
\hline Till & $1.5 \mathrm{RR}$ & 464 & 901 & 0.00523 & 0.344 \\
\hline
\end{tabular}




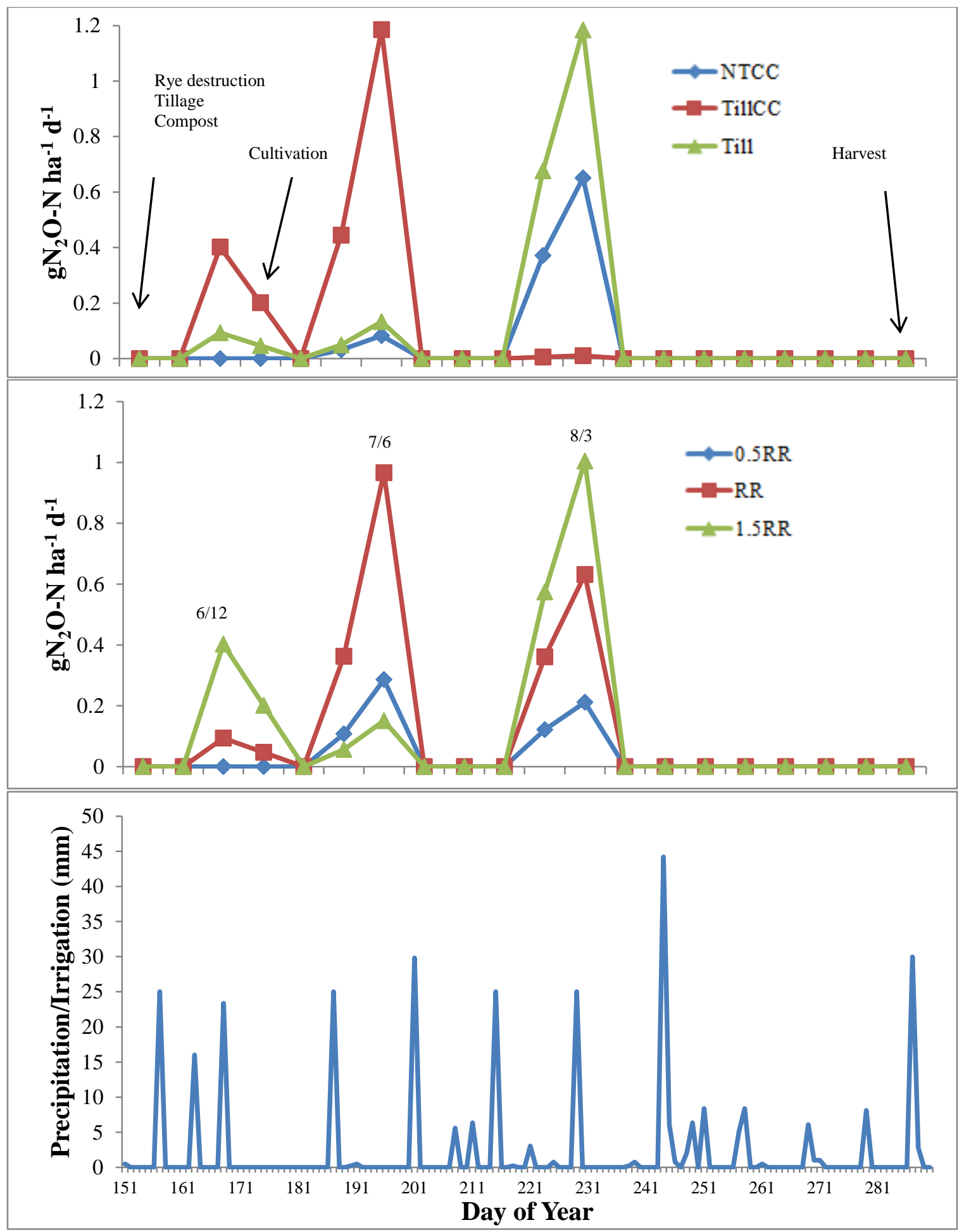

Figure 2-6. $\mathrm{N}_{2} \mathrm{O}$ emissions and daily precipitation or irrigation during the 2012 growing season 


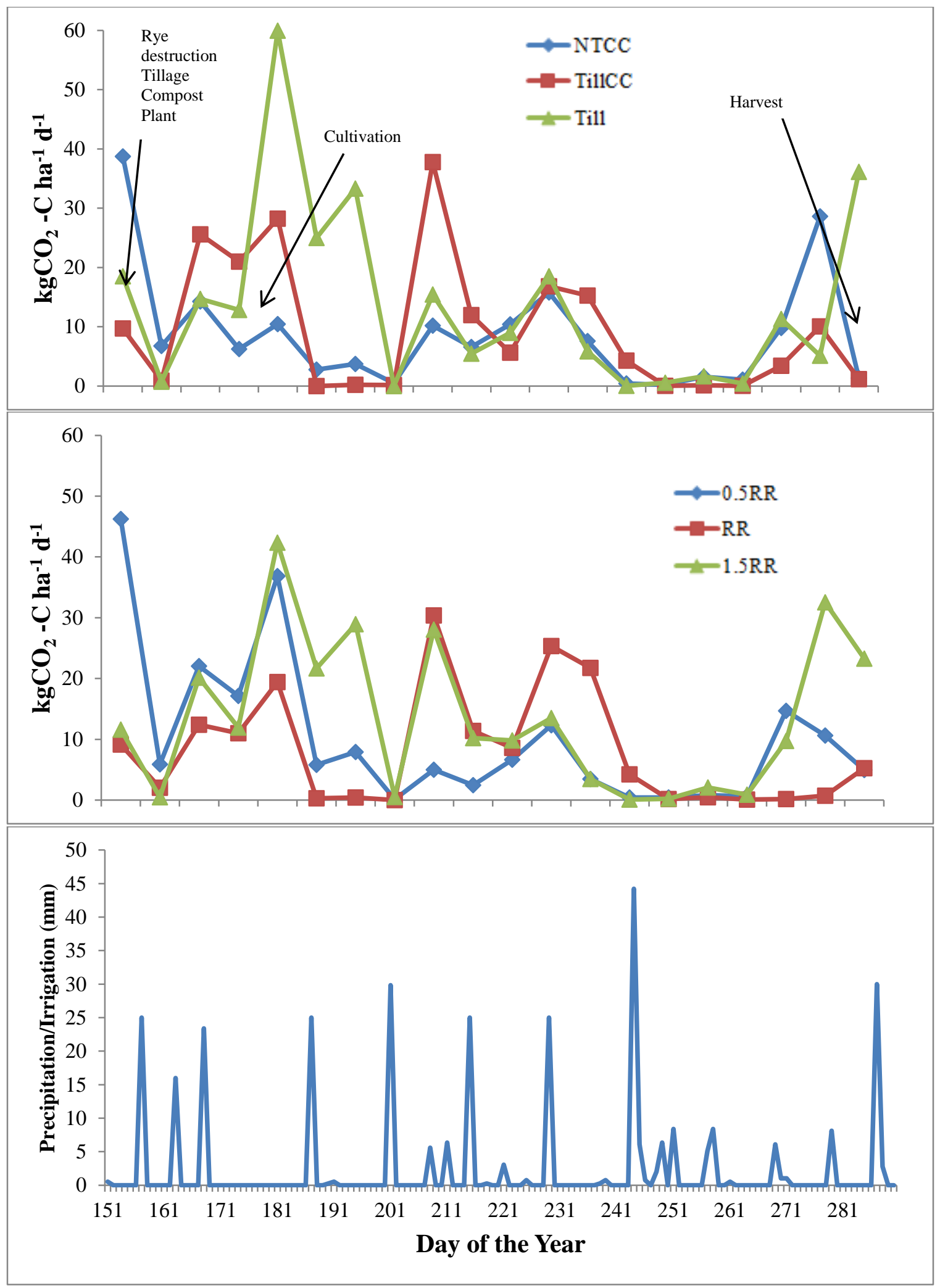

Figure 2-7. $\mathrm{CO}_{2}$ emissions and daily precipitation during the 2012 growing season. 


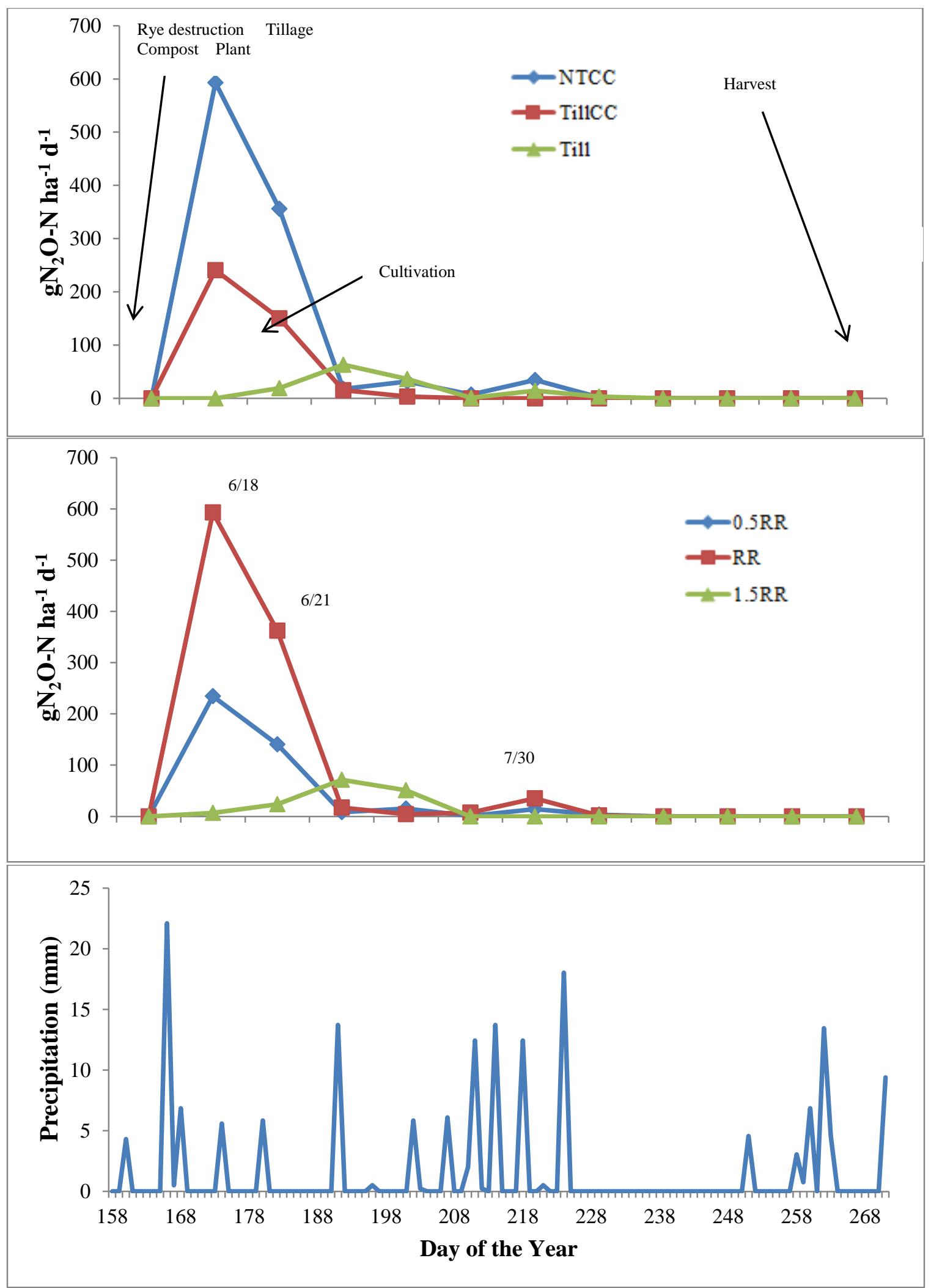

Figure 2-8. $\mathrm{N}_{2} \mathrm{O}$ emissions and daily precipitation during the 2013 growing season. 


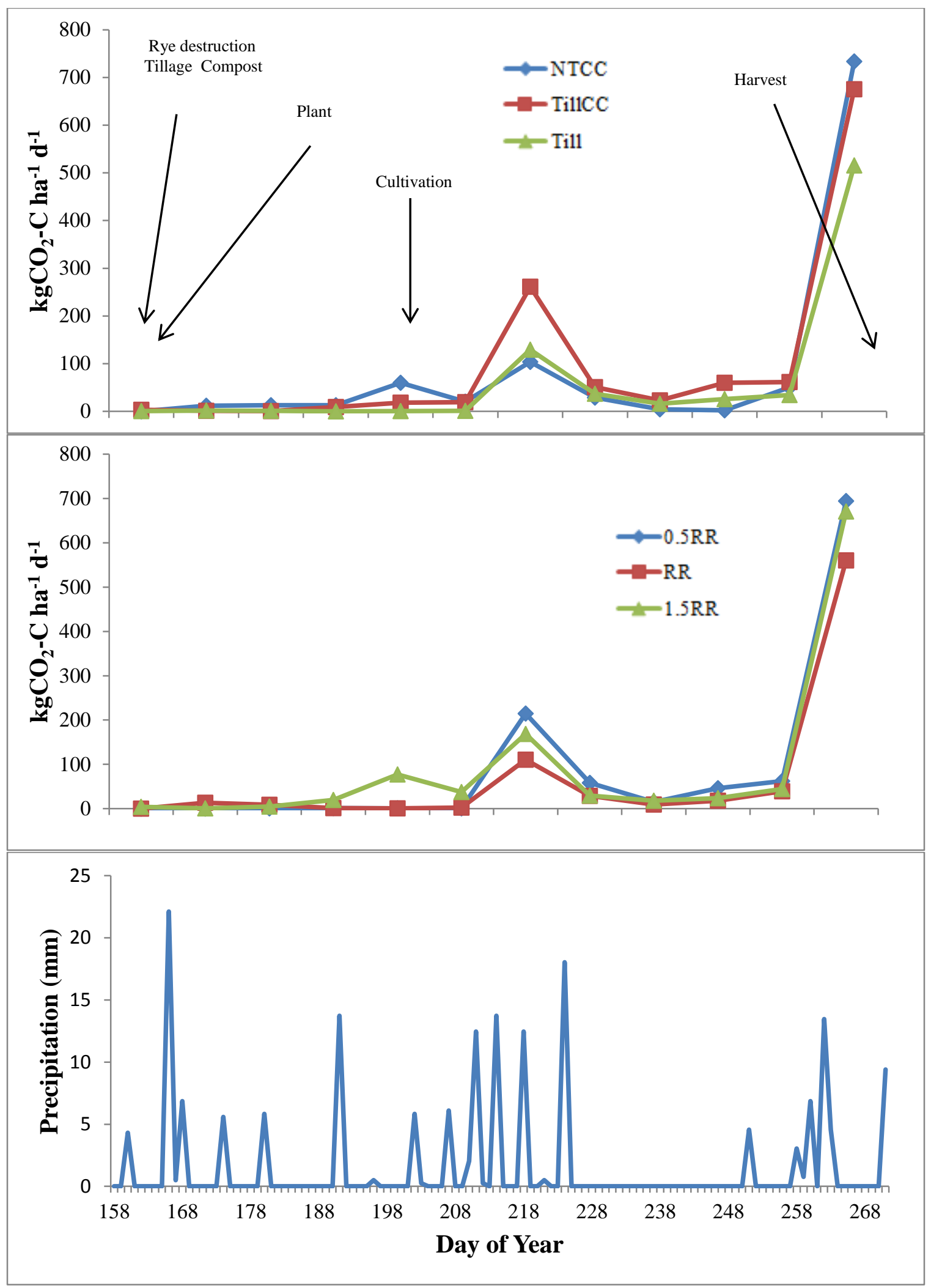

Figure 2-9. $\mathrm{CO}_{2}$ emissions and daily precipitation during the 2013 growing season. 
Table 2-7. Results of analysis of variance according to tillage/cover crop practice (TCCP) and compost treatments on $\mathrm{N}_{2} \mathrm{O}$ emissions under an organic soybean cropping system. Results reflect the emissions during three sampling dates in 2012 and 2013.

\begin{tabular}{|c|c|c|c|c|c|c|c|}
\hline \multicolumn{8}{|c|}{$\mathbf{N}_{2} \mathrm{O}$ Emissions $\left[\log \left(\mathrm{kg} \mathrm{N}_{2} \mathrm{O}-\mathrm{N} \mathrm{ha}^{-1}\right.\right.$ day $\left.\left.^{-1}+1\right)\right]$} \\
\hline Year & Date & Measurement & df & $\begin{array}{c}\text { Mean } \\
\text { Square }\end{array}$ & Error & $\begin{array}{c}\text { F- } \\
\text { Value }\end{array}$ & $\begin{array}{c}\text { P- } \\
\text { value }\end{array}$ \\
\hline \multirow[t]{9}{*}{2012} & $6 / 12$ & TCCP & 2 & 0.00003 & 6 & 1.00 & 0.42 \\
\hline & & Compost & 2 & 0.00003 & 8 & 0.78 & 0.47 \\
\hline & & TCCP x Compost & 4 & 0.00010 & 8 & 1.11 & 0.38 \\
\hline & $7 / 6$ & TCCP & 2 & 0.00345 & 6 & 1.02 & 0.32 \\
\hline & & Compost & 2 & 0.00341 & 8 & 0.87 & 0.45 \\
\hline & & TCCP x Compost & 4 & 0.00423 & 8 & 1.31 & 0.51 \\
\hline & $8 / 3$ & TCCP & 2 & 0.00034 & 6 & 0.67 & 0.35 \\
\hline & & Compost & 2 & 0.00212 & 8 & 1.04 & 0.42 \\
\hline & & TCCP x Compost & 4 & 0.00132 & 8 & 0.85 & 0.35 \\
\hline \multirow[t]{9}{*}{2013} & $6 / 18$ & TCCP & 2 & 0.00688 & 6 & 1.29 & 0.34 \\
\hline & & Compost & 2 & 0.00229 & 5 & 0.71 & 0.51 \\
\hline & & TCCP x Compost & 4 & 0.00248 & 5 & 0.77 & 0.56 \\
\hline & $6 / 21$ & TCCP & 2 & 0.01805 & 6 & 0.71 & 0.53 \\
\hline & & Compost & 2 & 0.02039 & 8 & 0.85 & 0.44 \\
\hline & & TCCP x Compost & 4 & 0.03958 & 8 & 1.65 & 0.21 \\
\hline & $7 / 30$ & ТCCP & 2 & 0.00140 & 6 & 0.54 & 0.61 \\
\hline & & Compost & 2 & 0.00136 & 8 & 0.58 & 0.57 \\
\hline & & TCCP x Compost & 4 & 0.00296 & 8 & 1.26 & 0.32 \\
\hline
\end{tabular}


Table 2-8. Effects of tillage/cover crop practice (TCCP) and compost treatments on $\mathrm{N}_{2} \mathrm{O}$ emissions of an organic soybean cropping system by year. Results reflect the emissions during three sampling events in 2012 and 2013.

\begin{tabular}{|c|c|c|c|c|c|c|c|}
\hline & & & ${ }_{2} \mathrm{O} \mathrm{Emi}$ & ions (g I & O-N ha-1 & $\left.y^{-1}\right)$ & \\
\hline & & & 2012 & & & 2013 & \\
\hline & & $6 / 12$ & $7 / 6$ & $8 / 3$ & $6 / 18$ & $6 / 21$ & $7 / 30$ \\
\hline TCCP & & & & & & & \\
\hline NTCC & & 0.0002 & 0.0015 & 0.0037 & 9.88 & 0.01 & 0.04 \\
\hline TillCC & & 0.0056 & 0.0120 & 0.0012 & 4.01 & 0.16 & 0.00 \\
\hline Till & & 0.0013 & 0.0013 & 0.0172 & 107.15 & 0.52 & 0.07 \\
\hline Compost & & & & & & & \\
\hline 0 & & 0.0001 & 0.0012 & 0.0041 & 3.91 & 0.00 & 0.06 \\
\hline $\mathrm{RR}$ & & 0.0013 & 0.0110 & 0.0010 & 9.88 & 0.17 & 0.04 \\
\hline $1.5 \mathrm{RR}$ & & 0.0056 & 0.0018 & 0.0158 & 107.26 & 0.52 & 0.00 \\
\hline TCCP $\times$ & ost & & & & & & \\
\hline NTCC & 0 & 0.0000 & 0.0000 & 0.0199 & 0.00 & 0.00 & 0.00 \\
\hline NTCC & $\mathrm{RR}$ & 0.0003 & 0.0013 & 0.0000 & 29.64 & 0.03 & 0.12 \\
\hline NTCC & $1.5 \mathrm{RR}$ & 0.0000 & 0.0139 & 0.0117 & 0.00 & 0.00 & 0.00 \\
\hline TillCC & 0 & 0.0000 & 0.0000 & 0.0000 & 11.72 & 0.00 & 0.00 \\
\hline TillCC & RR & 0.0000 & 0.0000 & 0.0012 & 0.00 & 0.49 & 0.00 \\
\hline TillCC & $1.5 \mathrm{RR}$ & 0.0167 & 0.0000 & 0.0000 & 0.32 & 0.00 & 0.00 \\
\hline Till & 0 & 0.0000 & 0.0248 & 0.0923 & 0.00 & 0.00 & 0.19 \\
\hline Till & $\mathrm{RR}$ & 0.0039 & 0.0000 & 0.0000 & 0.00 & 0.00 & 0.01 \\
\hline Till & $1.5 \mathrm{RR}$ & 0.0000 & 0.0000 & 0.0000 & 91.46 & 1.57 & 0.00 \\
\hline
\end{tabular}


Table 2-9. GHG emissions results from other studies. Conventional inputs were used.

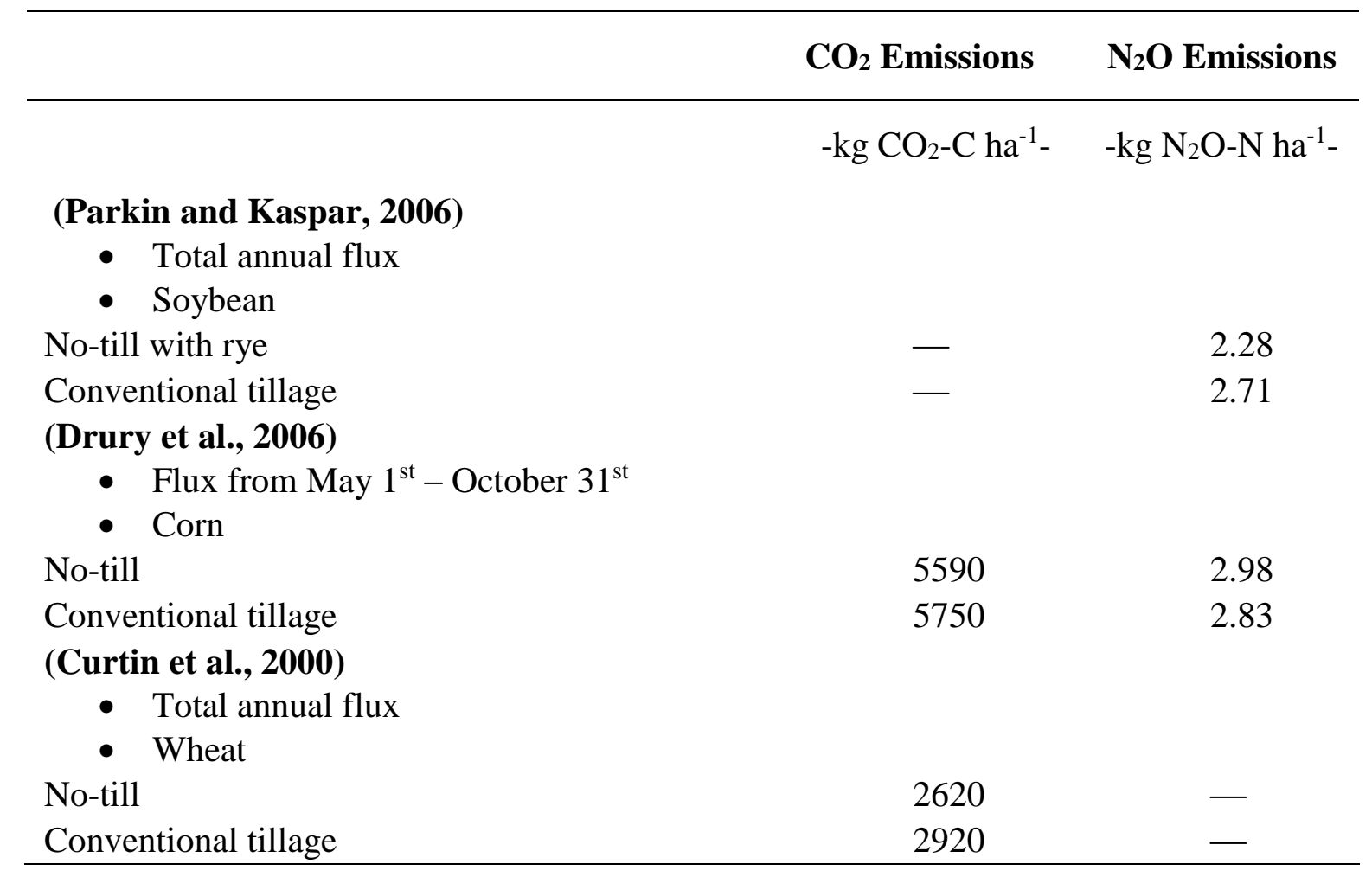




\subsection{REFERENCES}

Akiyama, H., McTaggart, I. P., Ball, B. C., and Scott, A. 2004. N2O, NO, and NH3 emissions from soil after the application of organic fertilizers, urea and water. Water, Air, and Soil Pollut. 156: 113-129.

AMS. 2014. National List of Allowed and Prohibited Substances. USDA. http://www.ams.usda.gov/AMSv1.0/NOPPetitionedSubstancesDatabase

Antle, J. M., and Ogle, S. M. 2012. Influence of soil C, N2O and fuel use on GHG mitigation with no-till adoption. Clim. Change 111:609-625.

Archer, D. W., Jaradat, A. A., Johnson, J. M., Weyers, S. L., Gesch, R. W., Forcella, F., and Kludze, H. K. 2007. Crop productivity and economics during the transition to alternative cropping systems. Agron. J. 99:1538-1547.

Baggs, E.M., M. Stevenson, M. Pihlatie, A. Regar, H. Cook and G. Cadisch. 2003. Nitrous oxide emissions following application of residues and fertiliser under zero and conventional tillage. Plant Soil 254:361-370. doi:10.1023/A:1025593121839.

Bailey, N. J., Motavalli, P. P., Udawatta, R. P., \& Nelson, K. A. 2009. Soil CO2 emissions in agricultural watersheds with agroforestry and grass contour buffer strips. Agrofor. Sys. 77(2):143-158.

Baldwin, K. R., and Greenfield, J. T. 2006. Composting on organic farms. Center for Environmental Farming Systems. North Carolina Extension Service, North Carolina.

Ball, B. C., Scott, A., and Parker, J. P. 1999. Field N2O, CO2 and CH 4 fluxes in relation to tillage, compaction and soil quality in Scotland. Soil and Tillage Res.53: 29-39.

Bouwman, A., L. Boumans and N. Batjes. 2002. Modeling global annual N2O and NO emissions from fertilized fields. Global Biogeochemical Cycles 16:28-21-28-29.

Brady, N.C. and R.R. Weil. 2010. Elements of the nature and properties of soils. Pearson Educational International. Upper Saddle River, NJ.

Bremner, J.M. and A.M. Blackmer. 1978. Nitrous Oxide: Emission from Soils During Nitrification of Fertilizer Nitrogen. Science 199: 295-296. doi:10.2307/1745661.

Curtin, D., H. Wang, F. Selles, B. McConkey and C. Campbell. 2000. Tillage effects on carbon fluxes in continuous wheat and fallow-wheat rotations. Soil Sci. Soc. Am. J. 64: 2080-2086. 
Drury, C., W. Reynolds, C. Tan, T. Welacky, W. Calder and N. McLaughlin. 2006. Emissions of nitrous oxide and carbon dioxide. Soil Sci. Soc. Am. J. 70: 570-581.

Eghball, B. 2002. Soil Properties as Influenced by Phosphorus- and Nitrogen-Based Manure and Compost Applications. Agron. J. 94:128-135.

Eichner, M.J. 1990. Nitrous oxide emissions from fertilized soils: summary of available data. J. Envir. Qual. 19:272-280.

Elmi, A.A., C. Madramootoo, C. Hamel, and A. Liu. 2003. Denitrification and $\mathrm{N}_{2} \mathrm{O}$ plus dinitogen ratios in the soil profile under three tillage systems. Biol. Fertil. Soils 38: $340-348$.

EPA 2013. Sources of Greenhouse Gas Emissions. United States Environmental Protection Agency. http://www.epa.gov/climatechange/ghgemissions/ sources.html.

Favoino, E. and D. Hogg. 2008. The potential role of compost in reducing greenhouse gases. Waste Management \& Research 26: 61-69. doi:10.1177/0734242x08088 584.

Follett, R. F., and Delgado, J. A. 2002. Nitrogen fate and transport in agricultural systems. J. Soil and Water Conserv. 57: 402-407.

Grandy, A. S., T.D. Loecke, S. Parr, and G. P. Robertson 2006. Long-Term Trends in $\mathrm{N}_{2} \mathrm{O}$ Emissions, Soil Nitrogen, and Crop Yields of Till and No-Till Cropping Systems. J. Envir. Qual. 35:1487-1495.

Healy, R. W., Striegl, R. G., Russell, T. F., Hutchinson, G. L., \& Livingston, G. P. 1996. Numerical Evaluation of Static-Chamber Measurements of Soil-Atmosphere Gas Exchange: Identification of Physical Processes. Soil Sci. Soc. Am. J. 60(3):740-747.

Hutchinson, G. and A. Mosier. 1981. Improved soil cover method for field measurement of nitrous oxide fluxes. Soil Sci. Soc. Am. J. 45: 311-316.

Lemke, R. L., Izaurralde, R. C., Nyborg, M., and Solberg, E. D. 1999. Tillage and N source influence soil-emitted nitrous oxide in the Alberta Parkland region. Can. J. Soil Sci. 79: 15-24.

Lesschen, J. P., Velthof, G. L., de Vries, W., and Kros, J. 2011. Differentiation of nitrous oxide emission factors for agricultural soils. Environ. Pollut. 159: 3215-3222. 
Li, C., S. Frolking and T.A. Frolking. 1992. A model of nitrous oxide evolution from soil driven by rainfall events: 1 . Model structure and sensitivity. Journal of Geophysical Research: Atmospheres 97: 9759-9776.

Li, C., S Frolking, TA Frolkin. 1992. A model of nitrous oxide evolution from soil driven by rainfall events: I. model structure and sensitivity. J. Geophys. Res. 97:97599776.

Lundegårdh, H. 1927. Carbon dioxide evolution of soil and crop growth. Soil Sci. 23: 417-453.

MacKenzie, A. F., Fan, M. X., and Cadrin, F. 1997. Nitrous oxide emission as affected by tillage, corn-soybean-alfalfa rotations and nitrogen fertilization. Can. J. Soil Sci. 77: 145-152.

Malhi, S. S., Lemke, R., Wang, Z. H., and Chhabra, B. S. 2006. Tillage, nitrogen and crop residue effects on crop yield, nutrient uptake, soil quality, and greenhouse gas emissions. Soil and Tillage Res. 90: 171-183.

Marland, G., B. McCarl and U. Schneider. 2001. Soil Carbon: Policy and Economics. Climatic Change 51: 101-117. doi:10.1023/A:1017575018866.

Myers, D. B., Kitchen, N. R., Sudduth, K. A., Sharp, R. E., and Miles, R. J. 2007. Soybean root distribution related to claypan soil properties and apparent soil electrical conductivity. Crop Sci. 47: 1498-1509.

NRCS, U. 2006. Land resource regions and major land resource areas of the United States, the Caribbean, and the Pacific Basin. US Department of Agriculture Handbook 296. ftp://ftp-fc.sc.egov.usda.gov/NSSC/Ag_Handbook_296/ Handbook_296_low.pdf

Parkin, T., A. Mosier, J. Smith, R. Venterea, J. Johnson, D. Reicoskyet al. 2003. USDAARS GRACEnet chamber-based trace gas flux measurement protocol. USDAARS, Washington DC. http://www.usmarc.usda.gov/SP2UserFiles/person/31831/ 2011\%20Parkin\%20and\%20Venterea\%20Trace\%20Gas\%20Protocol\%20Revisio n\%20Final.pdf

Parkin, T.B. and T.C. Kaspar. 2006. Nitrous oxide emissions from corn-soybean systems in the Midwest. J. Envir. Qual. 35: 1496-1506.

Paustian, K., W.J. Parton and J. Persson. 1992. Modeling soil organic matter in organicamended and nitrogen-fertilized long-term plots. Soil Sci. Soc. Am. J. 56:476488.

Raich, J.W. and C.S. Potter. 1995. Global patterns of carbon dioxide emissions from soils. Global Biogeochemical Cycles 9:23-36. 
Robertson, G.P., E.A. Paul and R.R. Harwood. 2000. Greenhouse gases in intensive agriculture: contributions of individual gases to the radiative forcing of the atmosphere. Science 289:1922-1925.

Smith, P., D. Martino, Z. Cai, D. Gwary, H. Janzen, P. Kumaret al. 2008. Greenhouse gas mitigation in agriculture. Philosophical Transactions of the Royal Society Bio. Sci. 363:789-813.

Snyder, C., T. Bruulsema, T. Jensen and P. Fixen. 2009. Review of greenhouse gas emissions from crop production systems and fertilizer management effects. Agriculture, Ecosystems \& Environment 133:247-266.

Staley, T., Boyer, D., and Caskey, W. 1990. Soil denitrification and nitrification potentials during the growing season relative to tillage. Soil Sci. Soc. Am. J. 54:1602-1608.

Stamatiadis, S., M. Werner and M. Buchanan. 1999. Field assessment of soil quality as affected by compost and fertilizer application in a broccoli field. Applied Soil Ecology 12:217-225.

Steiner, C., W.G. Teixeira, J. Lehmann, T. Nehls, J.L.V. de Macêdo, W.E. Blumet al. 2007. Long term effects of manure, charcoal and mineral fertilization on crop production and fertility on a highly weathered Central Amazonian upland soil. Plant Soil 291:275-290. 


\section{MANAGEMENT IMPACTS ON ORGANIC SOYBEAN YIELD}

\subsection{ABSTRACT}

As demand for organically grown food increases, growing soybean organically can be profitable and also improve soil ecosystem services through sustainable agronomic practices. However, because most chemical inputs are restricted from organic agriculture, producers rely heavily on tillage for weed control, which in turn can be detrimental to soil health. The use of cover crops, which can also be employed to suppress weed growth, may provide an alternative to tillage for sustaining yields. The purpose of this research was to investigate the effects of tillage, cover crop, and compost on yield of organically-grown soybean grown on Missouri claypan soil conditions.

A corn (Zea mays)-soybean (Glycine max)-wheat (Triticum aestivum) organic cropping system was initiated in 2012 at the University of Missouri Bradford Research Center near Columbia, MO using a randomized complete block, split-plot design with four replications. Each crop was investigated independently with tillage/cover crop combinations as the main plot treatment and compost rate for the split-plot treatment. Tillage/cover crop treatments included tilled without cover crop (Till), tilled with cover crop (TillCC), and no-till with cover crop (NTCC). Compost rates were based on soil-test phosphorous recommendations from the University of Missouri Soil Testing Laboratory. Compost treatments were 0 , half the recommended rate $(0.5 \mathrm{RR})$, the recommended rate (RR), and 1.5 times the recommended rate (1.5RR). 
Soybean from 2012 and 2013 are reported in this investigation. In 2012 organic soybean grown with tillage and without cover crop out-yielded tilled and no-till with cover crop by $0.88 \mathrm{Mg} \mathrm{ha}^{-1}$, while compost rate had no effect on yield. 2012 was characterized by a severe drought. Total precipitation was only $665 \mathrm{~mm}$, compared to 941 $\mathrm{mm}$ in 2013. Although tillage did not have an effect on yield for 2013, the RR and 1.5RR compost rates led to the highest yields. Yield response to compost rate varied by tillage/cover crop practice. For the no-till and cover crops yield generally increased with compost rate. For the tilled management systems (with or without cover crops) yield was suppressed at some of the intermediate compost rates. No agronomic explanation is available for this finding. Weed presence was $300 \%$ higher in plots with the $0.5 \mathrm{RR}$ than the 0 compost rate. However, the 0 compost rate was associated with the greatest soybean population count in 2013. These results suggest that tillage, cover crop practice, and compost rate can have an effect on organic soybean yield.

\subsection{INTRODUCTION}

Organic agriculture is increasing rapidly in the United States (Yussefi and Willer, 2007). This includes the state of Missouri, where farmers are becoming more interested in organic crop production (Cavigelli et al., 2008). As this interest is shared by farmers across the nation, there follows a desire for more information on proven organic system management practices. To meet this demand for information, universities and private agriculture companies are intensifying organic agriculture research. 
From the beginning of agriculture up until the industrial revolution and the introduction of synthetic fertilizers, farmers used organic methods to grow crops. Supplemental nutrients typically were provided in the form of manure and other organic wastes, and weed control was typically by manual methods with crude hand tools. However, these methods have been out of practice for many years, and advances in technology and the growth of the human population have changed the world substantially. When performed correctly, organic agriculture can ensure a consistent profit while sustaining or even increasing soil health (Bernstein et al., 2011).

Organically-grown soybean has received special attention in recent years. As a crop used around the world, soybean in general is the largest source of animal protein feed and the second largest source of vegetable oil directly consumed by humans (USDA-ERS, 2012). As such there has been a steady demand for organic soybean for both human consumption and animal feed (Delate et al., 2012). Organic livestock producers need organic grain crops to meet certified organic meat and dairy standards (Smith et al., 2011).

For organically-grown crops there are two considerations that dominate management efforts: 1) effective weed control to preserve water, light, and nutrients for the crop; and 2) adequate nutrient supply for the crop. When compared to conventionally raised (chisel-till/herbicide/fertilizer) soybean, yields for organic soybean are generally lower because of one or both of these considerations are not optimal for the crop. A study performed in Maryland found a 19\% yield reduction between organic and conventionally raised soybean (Cavigelli et al., 2008). To enjoy the potential profits and to help meet the demand for organic soybean, growers need quality research that provide management 
techniques that control weeds and provide adequate nutrients for optimal grain yield. Issues which may be resolved easily and quickly in a conventional system may be difficult to solve in an organic system.

Undoubtedly the most obvious and difficult crop management issue in organic grain cropping is weed control (Walz, 2004). A study comparing yield between organic and conventional soybean systems over several years found a $17.5 \mathrm{~kg} \mathrm{ha}^{-1}$ reduction in yield for every $1 \%$ increase in weed cover (Cavigelli et al., 2008). This same study cited weed competition as the principal reason for the $19 \%$ difference in yield between a conventional and organic soybean crop. Although organic herbicides do exist, they are not effective (Smith et al., 2010).

Tillage is the principal method used by organic producers to control weeds (Smith et al., 2010). As such organic production systems are typically more tillage-intensive than conventional systems. Often two or three cultivations are required following preplant primary tillage in organic systems to keep weeds in check (Place et al., 2009). Frequent use of tillage can be harmful to soil health by limiting the soil's function in food production and ecosystem services. Tillage may result in increased erosion and runoff, not only depleting soil resources but also contributing to water pollution (Takken et al., 2001). Tillage can also compact the soil beneath the tillage implement, increase bulk density, and accelerate loss of soil organic matter (SOM) (Lal, 1997).

Because of the negative effects of tillage, its use on conventional agricultural land has decreased over the past decade. Instead, there has recently been an increase in reduced tillage in conventional agriculture in the Corn Belt (Archer et al., 2007; Grandy, 2006). Through these reduced or no-till (NT) systems, the soil is tilled less extensively or 
not at all. Studies on long-term NT systems are showing increased yields, high organic carbon $(\mathrm{C})$, and reduced drought stress as a result of transitioning away from conventional tillage (CT) (Teasdale et al., 2007). Soil moisture is often observed to be higher in NT systems (MacKenzie et al., 1997), thus resulting in higher soil water availability under NT. Soil organic carbon (SOC) has been observed to increase in reduced tillage systems as well (Salinas-Garcia et al., 1997; Wood et al., 1991). No-till systems work well for conventional farmers because they are not restricted to organic standards of herbicide use (AMS, 2014). Organic farmers need alternative methods for suppressing weeds in NT systems.

Cover crops have been used by farmers for centuries (Ingels, 1998) to provide a wide variety of significant benefits such as repelling certain harmful insects, breaking up the subsoil, preventing soil erosion, enhancing nutrient and moisture availability, and provide additional soil organic matter (Clark, 2008). Further, these crops can suppress weed establishment, thus cover crops are considered an important management strategy in organic farming. Before planting of the cash crop in the spring, the cover crop in the organic managed systems must be destroyed through tillage, crimping, mowing, or some similar method (Clark, 2008).

An ideal cover crop to be planted before soybean is cereal rye (Secale cerale), also known as winter rye (Clark, 2008). This was the cover crop utilized in this investigation. Rye can be seeded later in fall than most other cover crops and still provide a substantial amount of above-ground growth. Also, its extensive root system helps to prevent soil erosion. Rye's quick establishment and tall growth make it a superb weed 
suppressant, as does its allelopathic capabilities. Rye residue can act as a weed suppressant four weeks after it is destroyed (Yenish et al., 1995).

Considering the many benefits cover crops can provide, they can be an ideal substitute for tillage when combined with organic agriculture. However, while they do offer many advantages, care has to be taken when managing cover crops, especially rye. If killed late in the planting season, rye can deplete soil water content, causing reductions in yield for rainfed environments (Liebl et al., 1992). Also, cover crops may immobilize essential nutrients soybean needs to thrive and produce profitable yields. Indeed, surveys of organic farmers indicate that soil fertility is the biggest challenge in organic grain production after weed control (Walz, 2004). For organic soybean to receive optimal nutrients, a fertilizer which meets federal organic standards must be utilized (AMS, 2014). A commonly used fertilizer is compost.

Compost may an especially important tool for organic producers utilizing NT, as it can increase soybean yields and thus help to eliminate yield differences between conventional and NT systems, although multiple annual applications may be necessary (Singer et al., 2004). Compost can provide many macro and micronutrients such as $\mathrm{P}, \mathrm{K}$, Ca, and Fe (Baldwin and Greenfield, 2006; Steiner et al., 2007). Soil surface C and N concentrations also may improve with compost applications (Eghball, 2002). Nutrients are not released as quickly as those supplied by synthetic fertilizers, thus nitrification of $\mathrm{N}$ occurs more slowly (Stamatiadis et al., 1999). Compost can increase soil $\mathrm{pH}$ and cation exchange capacity (Ouédraogo et al., 2001). The high cation exchange capacity of organic amendments may help stabilize soil nutrients (Stamatiadis et al., 1999). Additionally, compost can decrease bulk density and penetration resistance, and increase 
aggregate stability, porosity, soil organic carbon, water holding capacity, and infiltration rate (Cogger, 2005; Giusquiani et al., 1995; Khaleel et al., 1981; Martens and Frankenberger, 1992). The greatest accumulation of organic carbon occurs with the addition of stabilized amendments such as compost (Haynes and Naidu, 1998).

The effect of increasing water holding capacity with organic amendments may be especially important during periods of drought. Water holding capacity is increased at both low and high tensions through the increased porosity and surface area resulting from organic amendments (Gupta and Larson, 1979; Khaleel et al., 1981). However, while plant available water may increase with higher rates of compost, this effect may only be noticed after several years of application (Giusquiani et al., 1995). This organic fertilizer does come with a cost, and it is not always clear how much compost is needed for certain crops in specific growing conditions.

This study is unique in that the research area is characterized by a claypan soil. This soil has a consistent presence of an underlying claypan horizon. The layer of clay throughout this horizon has at least 100\% more clay than the superior horizon (Myers et al., 2007). The impact that this feature may have on soybean yield must be accounted for when comparing this investigation to similar studies elsewhere.

This investigation seeks to assess the impact of tillage, cover crop, and compost rate on yield and plant growth of organic soybean over claypan soils in central Missouri. 


\subsection{MATERIALS AND METHODS}

\subsubsection{RESEARCH SITE AND MANAGEMENT}

Research was established in the summer of 2011 at the University of Missouri Bradford Research and Extension Farm located southeast of the city of Columbia, Missouri. The research is located in an organic transition area, meaning all standards of nationally certified organic agriculture (AMS, 2014) were maintained throughout the study but not before it began.

The dominant soil series at the study site is a Mexico silt loam (fine, smectite, mesic Vertic Epiaqualf) with slopes of $1-4 \%$. This series is characterized by deep, poorly drained soils formed in loess over loamy sediments originating from glacial till. There also exists a consistent clayplan horizon in the subsurface soil, generally located landscape on ridges and hillsides of the Central Claypan Till Plains. The depth to the claypan varies depending on topography, ranging from $10 \mathrm{~cm}$ on eroded backslopes to $100 \mathrm{~cm}$ or more on depositional footslope areas. The mean annual temperature is $12^{\circ} \mathrm{C}$ and mean annual precipitation is 995 millimeters.

A crop rotation was established including both cash crops and cover crops (Figure 2-1). In the rotation winter wheat (Triticum aestivum, Bess variety) was planted in the fall and harvested in the late spring. Buckwheat (Fagopyrum esculentum, variety not stated) was planted during the wheat harvest and grew during the summer. During the second year of the rotation, rye and hairy vetch (Vicia villosa variety not stated) were planted in the fall at approximate seeding rates of $67 \mathrm{~kg} \mathrm{ha}^{-1}$ and $33.5 \mathrm{~kg} \mathrm{ha}^{-1}$ respectively into the 
buckwheat and grew until spring, whereupon they were destroyed through one of the cover crop destruction techniques, either by mowing or rolling/crimping. Corn (WS2992 from Welter Seed variety) was then planted at a seeding rate of 81,546 seeds ha ${ }^{-1}$ in 76 $\mathrm{cm}$ rows. When it was harvested in the fall, rye was planted at $101 \mathrm{~kg} \mathrm{ha}^{-1}$ for the final year of the rotation. In the spring, the rye was killed and soybean (389F.Y from Blue River Hybrids variety) was planted. When soybean was harvested in the fall, wheat was planted and the rotation cycle repeated.

For this study all cash crops of the rotation were initiated in 2012, although wheat was sown in 2012. This thesis is devoted only to the crop of soybean grown during the 2012 and 2013 seasons.

The study was conducted in a randomized complete block with a split-plot design and four replications (144 total plots). The crop area of soybean was divided into four complete blocks which included every treatment. Each block was $36 \times 27 \mathrm{~m}$ in size and was split into three $12 \times 9 \mathrm{~m}$ main plots (Figures 3-2 and 3-3).

Plots were characterized by one of three tillage/cover crop practices: Tillage without cover crop (Till), tillage with cover crop (TillCC), or no-tillage with cover crop (NTCC). Each of these three plots was subsequently divided into four $3 \times 9 \mathrm{~m}$ sub-plots of the split-plot design (Figures 3-2 and 3-3). Each of these was assigned one of four compost rates.

Compost rates were 0 , half the recommended rate $(0.5 \mathrm{RR})$, the recommended rate (RR), and 1.5 times the recommended rate (1.5RR) (Table 3-1). These rates were determined based on soybean phosphorous requirements as recommended by the University of Missouri soil testing lab. The compost was purchased from Central 
Missouri Poultry Producers in California, MO and was a composition of turkey manure and bedding materials. The product is certified organic and called Early Bird Compost. Nutrient tests showed an N-P-K ratio of 2.8-1.9-2.2.

Plots were managed each year according to tillage/cover crop practice. The rye in the NTCC plots was destroyed differently than the rye in the TillCC plots (Table 3-2). It was mowed in the TillCC plots to make tillage possible, while it was rolled in the NTCC plots. Rolling the rye instead of mowing it ensured a more complete barrier to weed growth.

The soybean used in this study was planted in $76 \mathrm{~cm}$ rows. Soybean was irrigated five times during 2012 with $2.5 \mathrm{~cm}$ of water applied at each irrigation event (Table 3-2). This was done because the 2012 growing season was exceptionally dry (Figure 3-4) and hot (Figure 3-5) when compared to 30 year averages. Irrigation was deemed necessary to provide the soybean crop with enough water for there to be any kind of grain production. Soybean was planted at the $2 \mathrm{~cm}$ depth at 156,800 seeds ha ${ }^{-1}$ using a no-till four-row John Deere 7100 cone planter. Soybean was harvested at physiological maturity using a Wintersteiger small plot combine. Soybean was weighed and yield was calculated according to each plot.

No irrigation was applied during 2013. Weather was more like the long term average, until the second half of the summer (Figure 3-5). Precipitation and growing degree data was taken from the Columbia Regional Airport Weather Station.

Several soybean growth measurements were taken during the growing seasons (Table 3-3). Soybean leaf samples were taken during the R1 reproduction stage of anthesis during both years. Twenty trifoliate leaves from random plants in each plot were 
removed by hand, dried, and then ground to a $0.5 \mathrm{~mm}$ fineness. Soybean grain was also ground to the $0.5 \mathrm{~mm}$ fineness. The ground leaf and grain samples were processed using a LECO analyzer for organic N (Nelson and Sommers, 1996).

Height and SPAD measurements were also taken during both years to monitor plant growth. Three plants were chosen from each plot. Three mature leaves were chosen from each of these plants and SPAD measurements were taken on these leaves to estimate chlorophyll content. Height was also measured from each chosen plant to determine.

Weed density and soybean population counts were measured during the 2013 growing season only. Weed densities were estimated once before cultivation using a $1 \mathrm{x} 1$ $\mathrm{m}^{2}$ quadrat made of PVC pipe. The square was tossed at random into each plot and the area in the square occupied by weeds was visually estimated as a percentage of the area surveyed.

Soybean population counts were conducted once during 2012. This was done using a $3 \mathrm{~m}$ PVC pipe which was placed between the two innermost rows of each plot. Every plant within the length of the $3 \mathrm{~m}$ pipe in each row was counted.

Data from soybean yield and other plant response measurements were analyzed using the General Linear Models procedure in SAS (Version 9.2, SAS Institute Inc., Cary, NC). When significant treatment effects were found, means comparisons were performed using least significant differences (LSD) at a significance level of 0.05 . 


\subsection{RESULTS AND DISCUSSION}

\subsubsection{YIELD}

\section{Tillage/Cover Crop Practice}

The tillage/cover crop practice affected yield in 2012 (Table 3-4). Soybean managed with tillage and no cover crop yielded more at $3.17 \mathrm{Mg} \mathrm{ha}^{-1}$ compared to NTCC and TillCC with means of $2.29 \mathrm{Mg} \mathrm{ha}^{-1}$ and $2.51 \mathrm{Mg} \mathrm{ha}^{-1}$, respectively (Table 3-5). This difference may be associated with water depletion from the cereal rye cover crop adding water stress on soybean yield during a year of low precipitation.

The year 2012 was characterized by a severe drought. A total of $125 \mathrm{~mm}$ of water was applied through irrigation over the course of the season (Table 3-2). However this did not begin until 6 days after compost had been applied and soybean had been planted. The $25 \mathrm{~mm}$ of water delivered at each irrigation event may not have been sufficient to recharge depleted soil water content. If the soil was dry, $25 \mathrm{~mm}$ would have wetted the soil only to a depth of about $15 \mathrm{~cm}$. A lack of subsurface moisture during a drought would have hindered soybean growth and development, and ultimately yield.

In 2013, tillage/cover crop practice did not have an impact on yield (Table 3-6). This can probably be attributed to the greater amount of precipitation which fell during 2013 (Figure 3-4). Total precipitation was $941 \mathrm{~mm}$, compared to $665 \mathrm{~mm}$ in 2012. The difference in precipitation during the growing season, from the beginning of May to harvest in mid-October, was even more substantial. In 2012 only $227 \mathrm{~mm}$ of rain fell from May $1^{\text {st }}$ to October $17^{\text {th }}$, when soybean was harvested. In contrast, twice as much 
rain $(460 \mathrm{~mm})$ fell from May $1^{\text {st }}$ to the October $14^{\text {th }}$ harvest in 2013. Thus the negative effect that rye had on the 2012 soybean crop was not an issue in 2013 as soil moisture was sufficient for both crops. Still, precipitation during the second half of 2013 was lower than the long term average (Figure 3-4).

\section{COMPOST RATE}

Composting did not affect yield in 2012, however it did during 2013 (Table 3-6). The RR and 1.5RR led to the highest yields at $2.25 \mathrm{Mg} \mathrm{ha}^{-1}$ and $2.28 \mathrm{Mg} \mathrm{ha}^{-1}$, respectively (Table 3-7). The 0 and $0.5 \mathrm{RR}$ yields were less at $2.08 \mathrm{Mg} \mathrm{ha}^{-1}$ and $1.96 \mathrm{Mg}$ $\mathrm{ha}^{-1}$, respectively. There are two possible reasons that compost affected yield in 2013 and not in 2012. First, precipitation was drastically different during the two growing years (Figure 3-5). Increased soil moisture during the much wetter year of 2013 would have stimulated faster decomposition of the compost, leading to a larger pool of available nutrients and thus greater soybean yields in plots with higher compost rates.

The other reason compost may have affected yield in 2013 may be because it was the second year that compost was added to the soil. With the exception of two plots, every plot in 2013 received the same compost rate as was delivered in 2012. Two years of compost amendments had been applied to the soil by 2013, and an accumulation effect could have occurred as nutrients built up in the soil. The multiple years of application also could have introduced positive changes to the soil observed in other studies, such as decreased bulk density, increased aggregate stability, porosity, and infiltration rate (Cogger, 2005, Martens and Frankenberger, 1992). Also, compost does increase water holding capacity (Giusquiani et al., 1995, Gupta and Larson, 1979, Khaleel et al., 1981). 
Because precipitation during the second half of the summer was below average (Figure 34), the higher compost rates may have increased plant available water, thereby having a positive effect on yield.

If this trend continues, more substantial differences in yield might be expected during ensuing years, as plots with higher compost rates gain greater soil fertility and other benefits associated with organic amendments.

\section{INTERACTION OF TILLAGE/COVER CROP PRACTICE AND COMPOST RATE}

In 2012 there were no interactions between tillage/cover crop practices and compost rates on yield, however interactions did occur during 2013 (Table 3-6). The soybean under the NTCC systems yielded more at the two highest compost rates (Table 3-7). Higher compost rates may have delivered more essential nutrients and provided additional soil benefits such as decreased evaporation and increased plant available water to the soybean, thereby increasing yield.

The effect of composting in tilled treatments was more complex. A possible explanation for these differences may be linked to the influence of tillage, the only variable distinguishing the NTCC plots from the TillCC and Till plots. The tillage performed in these latter plots may have led to accelerated decomposition of the compost material, whereas in the NTCC system the compost on the soil surface may have acted as a barrier to evaporation, thus helping to preserve soil moisture. Even though 2013 was closer to a normal precipitation year, periods of dry weather in July and August occurred that would have stressed crop growth and grain yield. The accumulation effect of two years of compost would have been more significant with NTCC. The impact of 
composting in tilled systems was inconsistent, and therefore difficult to explain. Because the composting effect was only observed for one year, it is difficult to make generalized assumptions. It is possible the observed effect could also be attributed to random error. More years of study under different environmental conditions are needed to better understand the implications of tillage and composting in organic soybean production.

\subsubsection{SOYBEAN HEIGHT}

\section{Tillage/Cover CROP Practice}

Tillage/cover crop practice affected height in 2012 (Table 3-4). The plants in the Till plots were taller than NTCC plots with average heights of $82.0 \mathrm{~cm}$ and $65.3 \mathrm{~cm}$ respectively (Table 3-5). These results are similar to those found between tillage/cover crop practice and yield during 2012 and are related to the negative effect of cover crop. The year 2012 was characterized by a severe drought, and the growth of cover crop prior to planting of soybean may have decreased subsurface soil moisture to lower levels than present in areas where no cover crop was grown. A lack of subsurface moisture during a drought would have hindered soybean growth and development, and ultimately height.

In 2013, tillage/cover crop practice did not have an effect on height. This may be because of the greater precipitation which occurred during 2013 (Figure 3-4).

\section{COMPOST RATE}

Compost rate did not have an effect on height for 2012 or 2013 (Table 3-4 and 3-

$6)$. 


\title{
InTERACTION OF TILlage/COVER CROP PRACTICE AND COMPOST RATE
}

In 2012 there were no interactions between tillage/cover crop practices and compost rates on height, however interactions did occur during 2013 (Table 3-6). For this year height was affected by compost rates for NTCC management. The 0 compost rate led to a significantly shorter height than any other compost rate (Table 3-7). This was likely due to a lack of nutrients combined with the NTCC management practices, which limited yield and height in NTCC plots for 2012. While yield and height were not affected by only tillage/cover crop practice in 2013 , the 0 compost rate seemed to have limited height in the NTCC plots (Figure 3-10).

\subsubsection{WEED PRESENCE}

\author{
Tillage/Cover Crop Practice
}

Tillage/cover crop practice did not affect weed presence in 2013 (Table 3-6).

\section{COMPOST RATE}

Compost rate had an effect on weed presence in 2013 (Table 3-6). There was a greater density of weeds for the 0.5RR than in plots with no compost (Table 3-7). The RR and $1.5 \mathrm{RR}$ did not lead to weed populations different than the 0 or $0.5 \mathrm{RR}$ levels, but did trend higher (Figure 3-11). Compost has been documented to increase weed growth (Blackshaw et al., 2005, Menalled et al., 2009) although it can also reduce weed emergence (Menalled et al., 2009). A possible explanation for the higher weed presence 
in $0.5 \mathrm{RR}$ soybean is that weed seeds which had not been effectively killed through the composting process were introduced into the soil through the compost and grew most successfully in the $0.5 \mathrm{RR}$ plots. However without actual evidence, this effect may be due only to random error. Also, weed presence was merely estimated once (Table 3-3). The effect of compost treatment on weed populations could have changed drastically later in the growing season.

\title{
InTERACTION OF TILlage/Cover CROP PRACTICE AND COMPOSt RATE
}

There were no interactions between tillage/cover crop practices and compost rates on weed presence in 2013 (Table 3-6).

\subsubsection{SOYBEAN POPULATION}

\author{
Tillage/Cover Crop Practice
}

Tillage/cover crop practice did not affect soybean population in 2013 (Table 3-6).

\section{Compost RAte}

Compost rate had an effect on soybean population in 2013 (Table 3-6). Plots with no compost had more soybean plants than plots provided with the RR of compost (Table $3-7)$. However the $0.5 \mathrm{RR}$ and $1.5 \mathrm{RR}$ did not lead to soybean populations significantly different than the 0 or RR levels (Figure 3-12). The reasoning behind these differences is again difficult to postulate. Because the highest mean population was associated with the 0 compost rate, the effect of compost may have suppressed germination, and thus 
soybean population. The compost most likely did not directly decrease germination. Instead, it may have increased weed growth, which would have created competition amongst soybean seedlings and weed plants for nutrients, water, and light. Indeed, compost rate was observed to increase weed presence (Figure 3-11). Also, the compost had not been sterilized prior to application, and may have introduced harmful pathogens. It seems that compost had an indirect suppression effect on soybean population, although without additional measurements no certain explanation can be given.

InTERACTION OF TILlage/COVER CROP PRACTICE AND COMPOST RATE

There were no interactions between tillage/cover crop practices and compost rates on soybean population in 2013 (Table 3-6).

\subsubsection{RESULTS: LEAF N, GRAIN N, AND SPAD}

Several other plant growth measurements were taken including leaf N, grain N, and SPAD measurements. Compost rate and tillage/cover crop practice did not have an effect on these variables for either 2012 or 2013 (Tables 3-4 and 3-6).

\subsubsection{DISCUSSION}

Successful management of organic soybean requires special attention to inputs and practices which may be novel to most producers. Utilization of compost as a 
fertilizer, while an ancient technique, has not commonly been employed in grain crop production for many years. To maximize yields, application rates must be specific to the nutrient requirements of the soybean while accounting for compost costs. Cover crops are another practice which has not been utilized regularly on a large scale for grain crop production but has received greater attention in recent years. Many advocates of cover crops recommend them as a powerful addition to a successful crop production strategy. One important advantage their use can offer organic producers is an alternative to tillage for weed control. However cover crops must be used carefully. Soybean yield may increase or decrease according to how they are managed and varying environmental conditions.

Several interesting results were obtained from this investigation related to the effect of tillage, cover crop, and compost on yield of organically grown soybean. Till plots, which did not have a cover crop and were tilled using a four-row Danish tine cultivator, were associated with the highest yields for 2012. Lower yields in NTCC and TillCC plots were likely in response to a lack of soil moisture initiated by the severe drought of 2012 and exasperated by the effect of cover crop growth on soil water. During this study rye was destroyed on the same day as planting in 2012. Because it was allowed to grow late into the season, soil water content was depleted, causing a negative effect on soybean yield.

Compost rate affected soybean yield in a more positive manner. Yields were higher for the RR and 1.5RR during 2013. The greater amount of precipitation which characterized the 2013 growing season may have stimulated faster decomposition of the compost, leading to a larger pool of available nutrients. These nutrients led to greater 
yields for soybean in plots with higher compost levels, an effect not observed during 2012. Also, 2013 was the second year the compost was applied at the same rates to the soil. The multiple years of application also could have introduced positive changes to the soil such as decreased bulk density, increased aggregate stability, porosity, and infiltration rate (Cogger, 2005, Martens and Frankenberger, 1992). Because precipitation during the second half of the summer was below average, the higher compost rates may have decreased evaporation and increased plant available water, thereby having a positive effect on yield.

Compost rate also had an effect on soybean population, although not in a straightforward manner. Soybean population was highest in plots which did not receive compost, although this number was not different from the $0.5 \mathrm{RR}$ and $1.5 \mathrm{RR}$ plots. The RR plots had the lowest average soybean density. This is surprising because the RR plots, along with the $1.5 \mathrm{RR}$ plots, led to the highest yields during 2013. So although though the RR plots had fewer plants, they were higher yielding than the 0 and $0.5 R R$ plants.

Other yield variables tested were not affected by tillage/cover crop practice or compost rate, including leaf and seed organic N content and SPAD measurements.

\subsection{CONCLUSION}

The results of this investigation suggest that tillage, cover crop practice, and compost rate interact in a complex manner and should be managed carefully for maximum soybean yields. Cover crops employed to help suppress weeds and ensure optimal soil water for the cash crops may under some management and weather 
conditions ironically act as a weed by exhausting soil moisture. Ample time must be provided between rye cover crop destruction and planting of soybean. Rye destruction was performed on the same day and one day before planting during this study. However, based on the results of this study more time should pass between cover crop destruction and planting. This will ensure that soil moisture levels can recover from rye growth. Also, it provides time for the cover crop to decompose, so potential allelopathic effects are avoided and nutrients derived from the cover crop can be made available to the following crop.

The nutrients in compost are not quickly available to plants. Decomposition and release of nutrients takes time and this should be considered when deciding when to apply the compost. Warm temperatures and precipitation may speed up decomposition, so if possible compost should be applied before a rainfall event. Also, multiple years may need to pass before the full potential of compost is observed, as soil fertility and physical properties improve over time.

As when using any fertilizer, an increase in weeds may occur after application of compost. During this study weed presence was not statistically different between plots which received compost. However weed response to compost rate may vary between weed species and type of compost. The effect of organic fertilizers on weed population dynamics is inconsistent, so broad generalizations should be avoided (Barberi, 2002).

Soybean response to compost rate may also be complex. As in the case of this study, soybean yields were highest in plots which received more compost (RR and 1.5RR plots) however soybean plant densities were lowest in RR plots. So although plant populations may seem low, the individual plants may be high yielding. 
Modern organic agriculture research is still in its infancy. This is particularly true of recent trending strategies attempting to use cover crops. Additional research is necessary to determine the ideal method of producing organic soybean using cover crops with or without tillage. This research needs to include a variety of environmental factors such as soil type, species of cover crop, and timing and method of cover crop destruction. Particular focus should be placed on how much time is required between cover crop destruction and planting of the proceeding crop to avoid the potential negative effects of cover crops. The ideal type and rate of compost for growing organic soybean also needs further research. Compost is not as predictable as synthetic fertilizer, but additional studies on its use would contribute to an increased understanding of how it responds to variants in the environment such as precipitation and cover crops.

Cover crops can offer an alternative to tillage which not only prevents soil damage but can increase its health. However if not managed correctly, no-till cover crop systems may decrease yields. Compost rate is an ideal fertilizer for organic producers, but must also be managed carefully. Higher applications rates of compost may only result in higher yields after several subsequent years of application. Organic agriculture is a novel industry and best management practices are still not completely known. Successful management of organic grain crops such as soybean requires an understanding of the complex interactions of inputs and practices such as cover crop and compost use. 


\subsection{TABLES AND FIGURES}

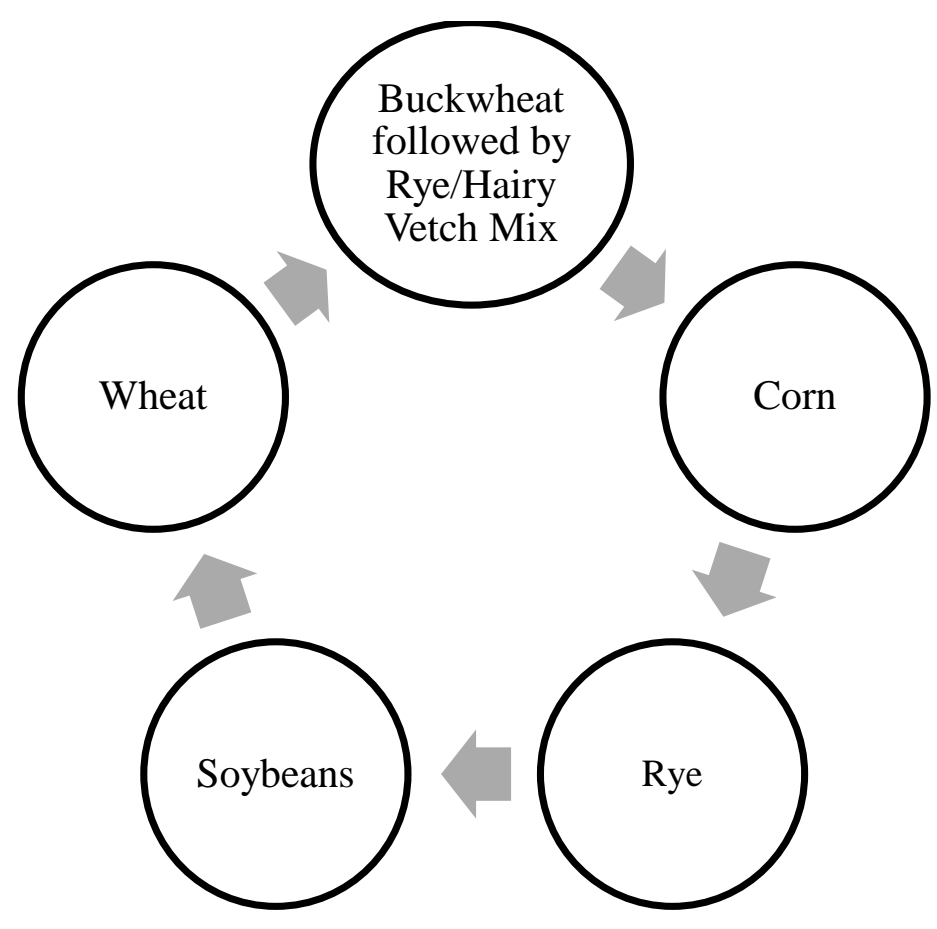

Figure 3-10. Crop rotation followed during this study. 


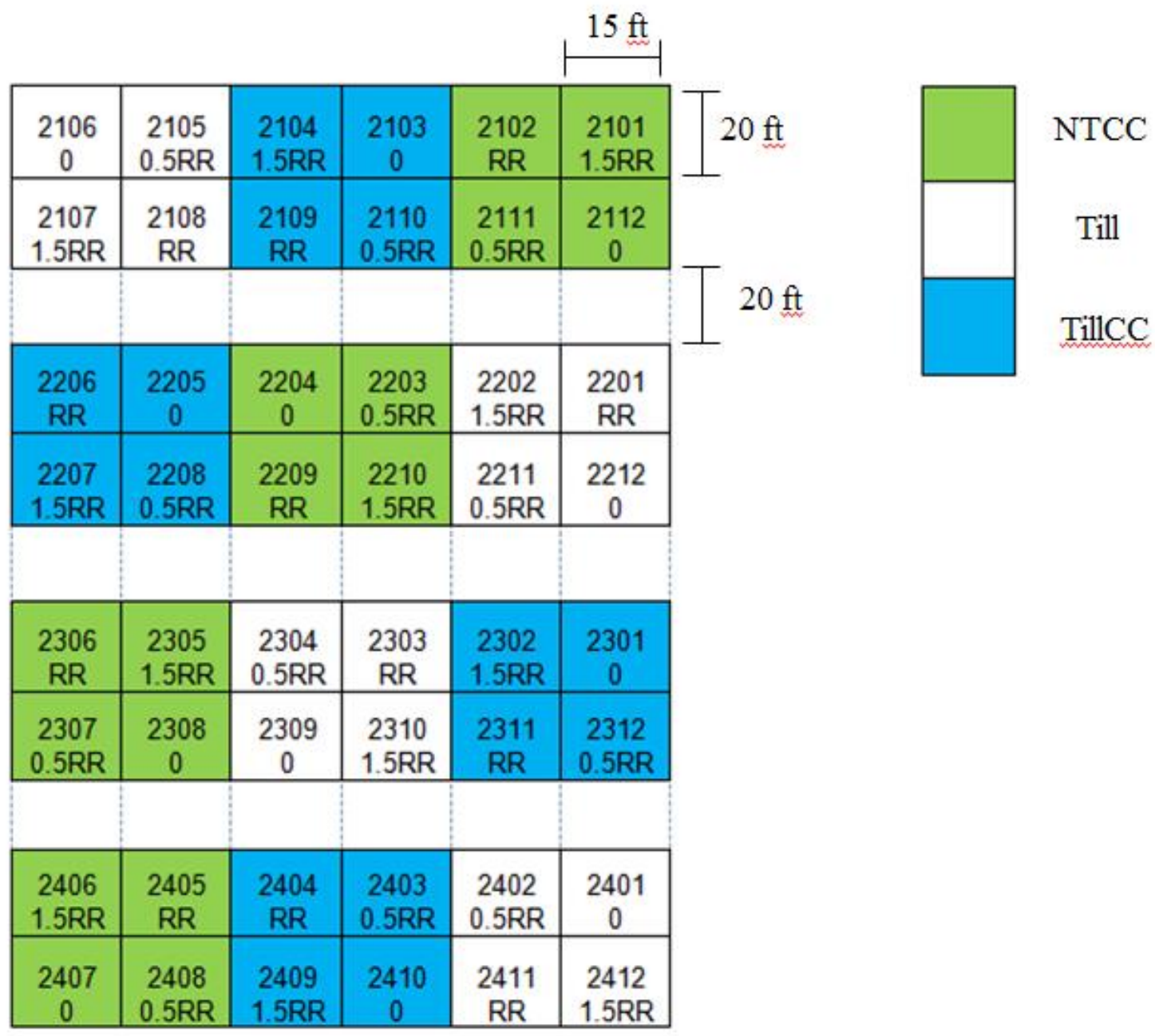

Figure 3-11. Research plot plan for 2012. NTCC: No-till cover crop, Till: Tilled without cover crop, TillCC: Tilled with cover crop. 0.5RR: Half the recommended compost rate, RR: The recommended compost rate, 1.5RR: One and a half times the recommended compost rate. 


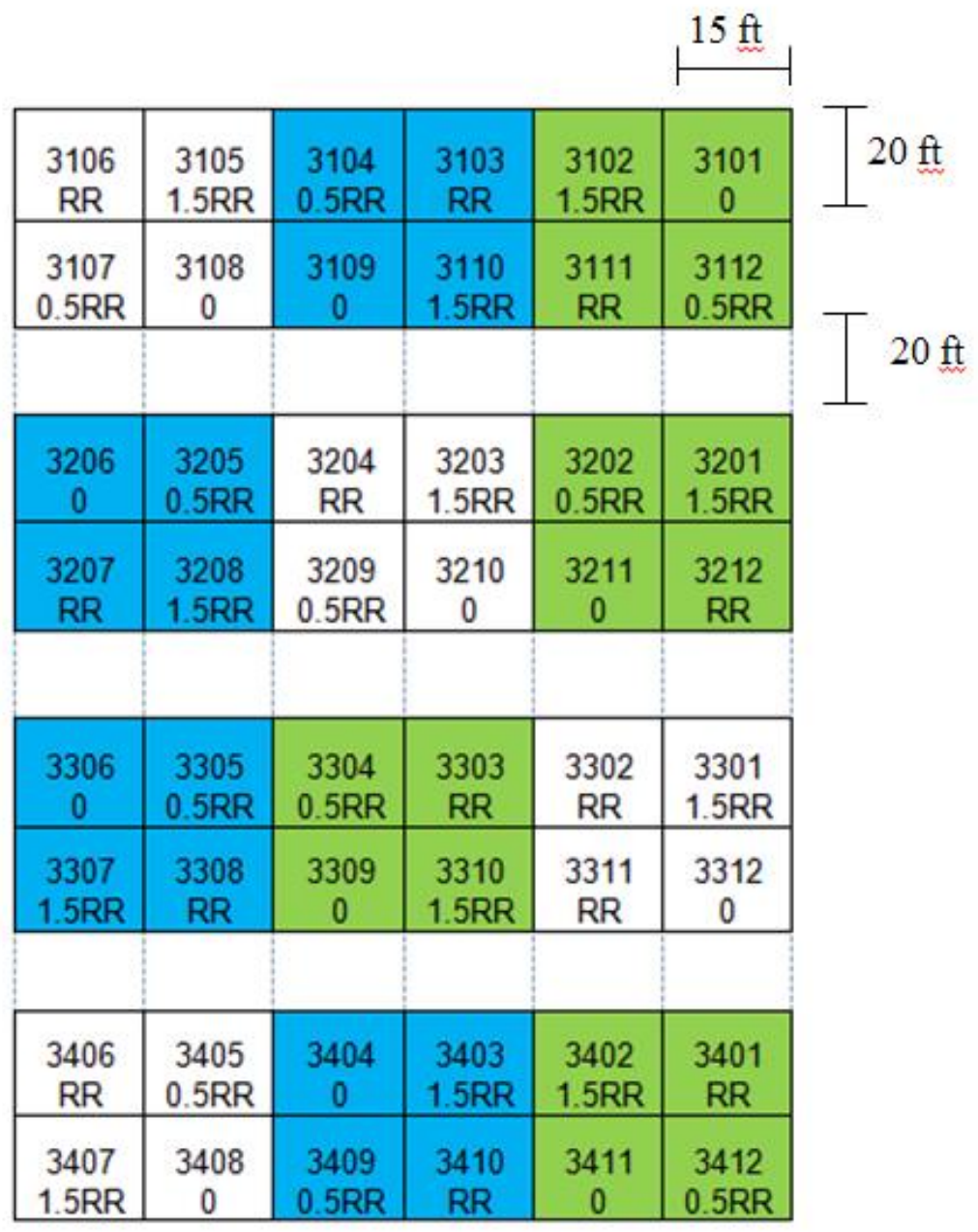

NTCC

Till

TillCC

Figure 3-12. Research plot plan for 2013. NTCC: No-till cover crop, Till: Tilled without cover crop, TillCC: Tilled with cover crop. 0.5RR: Half the recommended compost rate, RR: The recommended compost rate, 1.5RR: One and a half times the recommended compost rate.

Table 3-10. Compost rates during the 2012 and 2013 growing seasons of this study.

\begin{tabular}{cccc}
\hline Compost Rate & kg/ha applied & kg/ha P & kg/ha N \\
\hline 0 & 0 & 0 & 0 \\
$0.5 \mathrm{RR}$ & 2654 & 50 & 73 \\
RR & 5309 & 100 & 147 \\
$1.5 \mathrm{RR}$ & 7963 & 151 & 221 \\
\hline
\end{tabular}


Table 3-11. Management techniques and dates utilized during this investigation. TCCP: Tillage/cover crop practice. NTCC: No-till cover crop, Till: Tilled without cover crop, TillCC: Tilled with cover crop. N/A: Not applicable.

\begin{tabular}{|c|c|c|c|c|c|c|c|c|}
\hline Year & ТССР & $\begin{array}{c}\text { Rye } \\
\text { planted }\end{array}$ & Rye destruction & $\begin{array}{c}\text { Compost } \\
\text { applied }\end{array}$ & $\begin{array}{c}\text { Irrigation } \\
\text { applied }\end{array}$ & Tillage & $\begin{array}{c}\text { Soybean } \\
\text { planted }\end{array}$ & Harvest \\
\hline \multirow{3}{*}{2012} & NTCC & & Roller crimper 5/29 & \multirow{3}{*}{$5 / 29$} & $6 / 5$ & N/A & \multirow{3}{*}{$5 / 29$} & \multirow{3}{*}{$10 / 17$} \\
\hline & TillCC & $10 / 8 / 2011$ & Flail mower 5/29 & & $\begin{array}{c}7 / 5 \\
7 / 19 \\
8 / 2\end{array}$ & $\begin{array}{l}5 / 29 \\
6 / 21\end{array}$ & & \\
\hline & Till & & N/A & & $8 / 16$ & & & \\
\hline \multirow[t]{3}{*}{2013} & NTCC & \multirow{3}{*}{$10 / 19 / 2012$} & Roller crimper $6 / 11$ & \multirow{3}{*}{$6 / 11$} & \multirow{3}{*}{ N/A } & N/A & \multirow{3}{*}{$6 / 12$} & \multirow{3}{*}{$10 / 14$} \\
\hline & TillCC & & Flail mower 6/11 & & & $\begin{array}{l}6 / 11 \\
7 / 11\end{array}$ & & \\
\hline & Till & & N/A & & & & & \\
\hline
\end{tabular}


Table 3-12. Dates for plant response measurements by cropping system.

\begin{tabular}{ccccccc}
\hline Year & $\begin{array}{c}\text { Weed } \\
\text { Presence }\end{array}$ & Leaf N & SPAD & $\begin{array}{c}\text { Soybean } \\
\text { Height }\end{array}$ & $\begin{array}{c}\text { Soybean } \\
\text { Population }\end{array}$ & Grain N \\
\hline 2012 & - & $8 / 8$ & $8 / 8$ & $8 / 8$ & - & $10 / 17$ \\
2013 & $7 / 11$ & $8 / 9$ & $8 / 9$ & $8 / 9$ & $8 / 25$ & $10 / 14$ \\
\hline
\end{tabular}




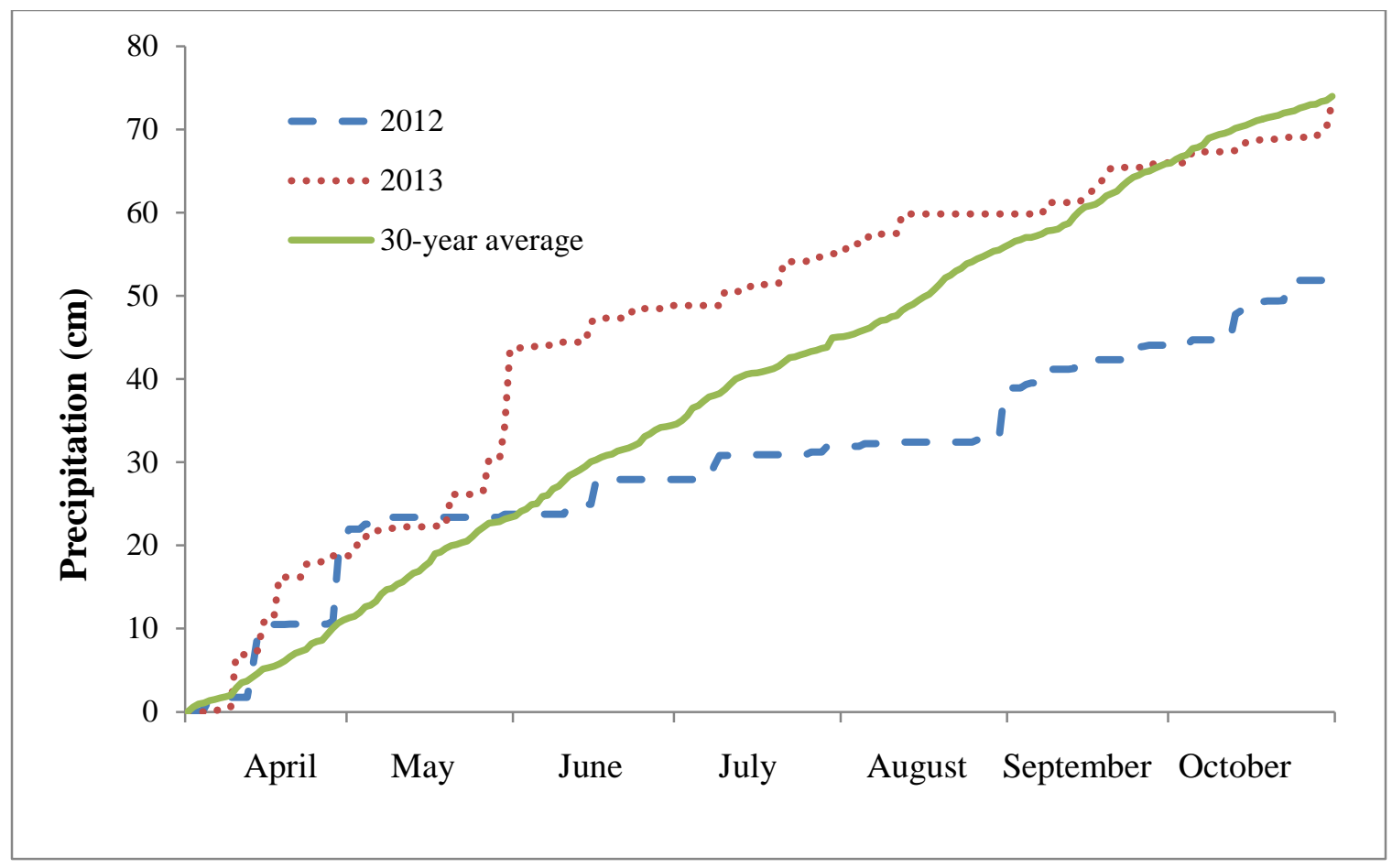

Figure 3-13. Precipitation (cm) for the months of April - October during 2012, 2013, and the 30 year average.

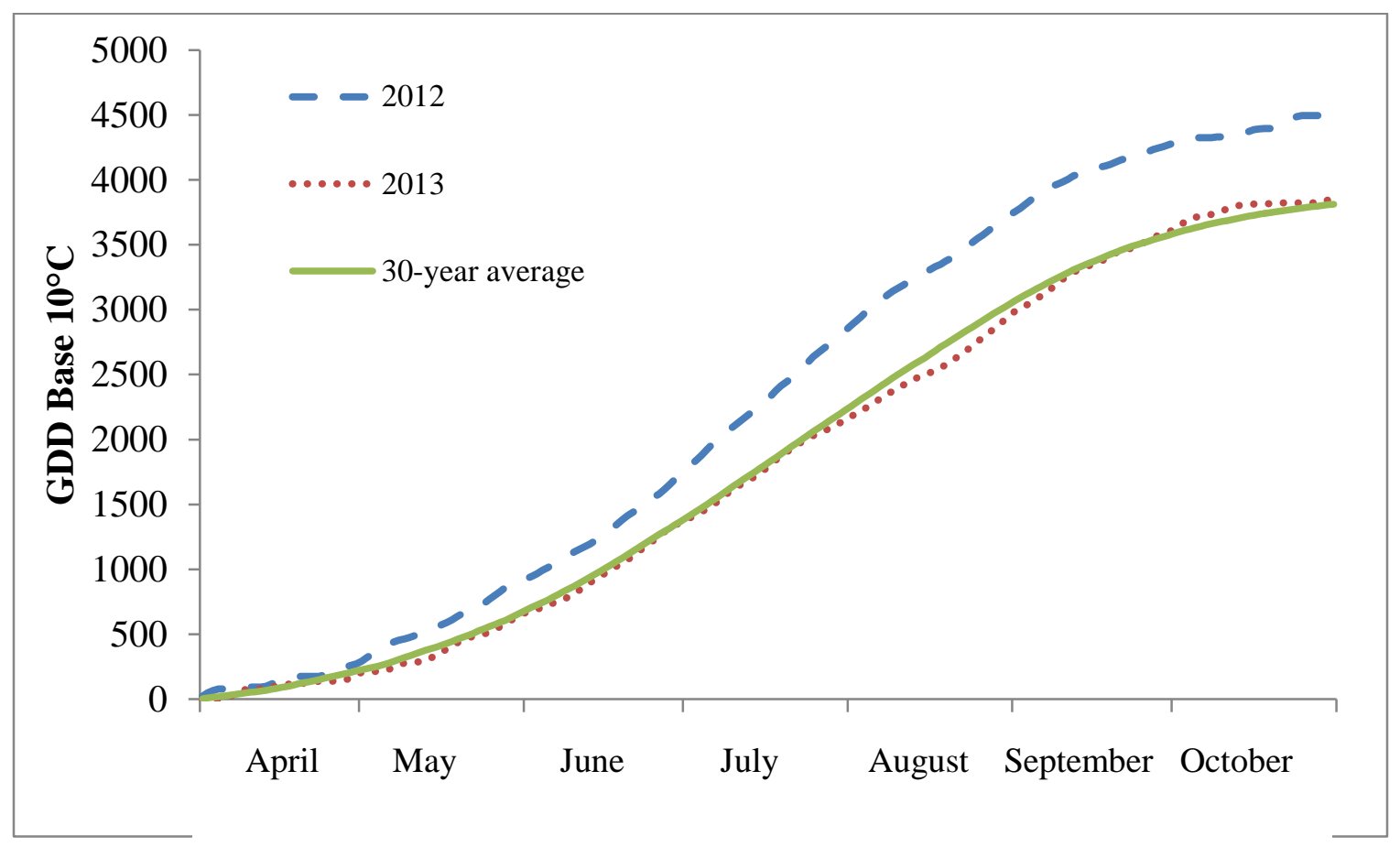

Figure 3-14. Growing degree days (GDD) base $10^{\circ} \mathrm{C}$ for the months of April - October during 2012, 2013, and the 30 year average. 
Table 3-13. Analysis of variance results according to tillage/cover crop practice (TCCP) and compost treatments on yield and growth measurements of 2012 organic soybean.

\begin{tabular}{lccccc}
\hline \multicolumn{1}{c}{ Measurement } & df & $\begin{array}{c}\text { Mean } \\
\text { Square }\end{array}$ & Error & F Value & P-value \\
\hline Yield $\left(\mathrm{Mg} \mathrm{ha}^{-1}\right)$ & 2 & 3.406 & 6 & 7.95 & 0.02 \\
TCCP & 3 & 0.327 & 27 & 1.85 & 0.16 \\
Compost & 6 & 0.040 & 27 & 0.23 & 0.96 \\
TCCP x Compost & & & & & \\
Leaf N $(\%)$ & 2 & 1.276 & 6 & 1.56 & 0.29 \\
TCCP & 3 & 0.305 & 23 & 0.78 & 0.52 \\
Compost & 6 & 0.586 & 23 & 1.5 & 0.22 \\
TCCP x Compost & & & & & \\
Grain N $(\%)$ & 2 & 0.253 & 6 & 2.75 & 0.14 \\
TCCP & 3 & 0.029 & 27 & 1.02 & 0.40 \\
Compost & 6 & 0.024 & 27 & 0.85 & 0.54 \\
TCCP x Compost & & & & & \\
SPAD & 2 & 1.098 & 6 & 1.92 & 0.23 \\
TCCP & 3 & 0.571 & 27 & 2.78 & 0.06 \\
Compost & 6 & 0.419 & 27 & 2.03 & 0.10 \\
TCCP x Compost & & & & & \\
Height (cm) & 2 & 1116.187 & 6 & 6.7 & 0.03 \\
TCCP & 3 & 103.660 & 27 & 1.53 & 0.23 \\
Compost & 26.860 & 27 & 0.4 & 0.88 \\
TCCP x Compost & 6 & & & & \\
\hline
\end{tabular}


Table 3-14. Tillage/cover crop practice (TCCP) and compost treatment means on yield and growth measurements of 2012 organic soybean.

\begin{tabular}{|c|c|c|c|c|c|c|}
\hline \multicolumn{2}{|c|}{ Main Effect } & Yield & Leaf $\mathbf{N}$ & Grain N & SPAD & Height \\
\hline & & $\mathrm{Mg} \mathrm{ha}^{-1}$ & & & & $\mathrm{~cm}$ \\
\hline \multicolumn{7}{|l|}{ TCCP } \\
\hline NTCC & & $2.29 \mathrm{a}$ & 5.4 & 6.3 & 51.61 & $65.3 \mathrm{a}$ \\
\hline TillCC & & $2.51 \mathrm{a}$ & 5.4 & 6.2 & 51.77 & 73.0ab \\
\hline Till & & $3.17 \mathrm{~b}$ & 4.9 & 6.1 & 52.12 & $82.0 \mathrm{~b}$ \\
\hline \multicolumn{7}{|c|}{ Compost } \\
\hline 0 & & 2.44 & 5.3 & 6.3 & 51.8 & 69.2 \\
\hline $0.5 \mathrm{RR}$ & & 2.69 & 5.3 & 6.2 & 52.1 & 74.1 \\
\hline $\mathrm{RR}$ & & 2.84 & 5.3 & 6.2 & 51.8 & 76.1 \\
\hline $1.5 \mathrm{RR}$ & & 2.65 & 5.0 & 6.2 & 51.6 & 74.2 \\
\hline \multicolumn{7}{|c|}{ TCCP x Compost } \\
\hline NTCC & 0 & 2.10 & 5.4 & 6.4 & 51.9 & 61.2 \\
\hline NTCC & $0.5 \mathrm{RR}$ & 2.34 & 5.3 & 6.3 & 52.1 & 67.5 \\
\hline NTCC & $\mathrm{RR}$ & 2.51 & 5.5 & 6.3 & 51.5 & 65.1 \\
\hline NTCC & $1.5 \mathrm{RR}$ & 2.20 & 5.5 & 6.3 & 51.1 & 67.3 \\
\hline TillCC & 0 & 2.32 & 5.3 & 6.2 & 51.4 & 67.3 \\
\hline TillCC & $0.5 \mathrm{RR}$ & 2.41 & 5.2 & 6.2 & 51.9 & 71.1 \\
\hline TillCC & RR & 2.78 & 5.7 & 6.2 & 52.0 & 78.8 \\
\hline TillCC & $1.5 \mathrm{RR}$ & 2.52 & 5.3 & 6.3 & 51.8 & 74.8 \\
\hline Till & 0 & 2.91 & 5.4 & 6.2 & 52.2 & 79.2 \\
\hline Till & $0.5 \mathrm{RR}$ & 3.31 & 5.4 & 6.1 & 52.5 & 83.8 \\
\hline Till & $\mathrm{RR}$ & 3.25 & 4.8 & 6.0 & 51.8 & 84.3 \\
\hline Till & $1.5 \mathrm{RR}$ & 3.23 & 4.1 & 6.0 & 52.0 & 80.5 \\
\hline
\end{tabular}


Table 3-15. Analysis of variance results according to tillage/cover crop practice (TCCP) and compost treatments on yield and growth measurements of 2013 organic soybean.

\begin{tabular}{|c|c|c|c|c|c|}
\hline Measurement & df & $\begin{array}{c}\text { Mean } \\
\text { Square } \\
\end{array}$ & Error & F Value & P-value \\
\hline \multicolumn{6}{|l|}{ Yield $\left(\mathrm{Mg} \mathrm{ha}^{-1}\right)$} \\
\hline TCCP & 2 & 0.143 & 6 & 0.84 & 0.48 \\
\hline Compost & 3 & 0.281 & 27 & 7.64 & $<0.01$ \\
\hline TCCP x Compost & 6 & 0.200 & 27 & 5.44 & $<0.01$ \\
\hline \multicolumn{6}{|l|}{ Leaf N $(\%)$} \\
\hline TCCP & 2 & 0.121 & 6 & 1.31 & 0.34 \\
\hline Compost & 3 & 0.081 & 23 & 0.66 & 0.59 \\
\hline TCCP x Compost & 6 & 0.134 & 23 & 1.08 & 0.40 \\
\hline \multicolumn{6}{|l|}{ Grain N (\%) } \\
\hline TCCP & 2 & 0.074 & 6 & 1.97 & 0.22 \\
\hline Compost & 3 & 0.018 & 27 & 0.38 & 0.77 \\
\hline TCCP x Compost & 6 & 0.039 & 27 & 0.78 & 0.60 \\
\hline \multicolumn{6}{|l|}{ SPAD } \\
\hline TCCP & 2 & 0.182 & 6 & 0.17 & 0.85 \\
\hline Compost & 3 & 0.417 & 27 & 1.32 & 0.29 \\
\hline TCCP x Compost & 6 & 0.459 & 27 & 1.45 & 0.23 \\
\hline \multicolumn{6}{|l|}{ Height $(\mathrm{cm})$} \\
\hline TCCP & 2 & 17.151 & 6 & 0.36 & 0.71 \\
\hline Compost & 3 & 49.452 & 27 & 2.43 & 0.09 \\
\hline TCCP x Compost & 6 & 62.496 & 27 & 3.07 & 0.02 \\
\hline \multicolumn{6}{|l|}{ Weeds $(\%)$} \\
\hline TCCP & 2 & 621.438 & 6 & 1.45 & 0.31 \\
\hline Compost & 3 & 896.520 & 27 & 3.93 & 0.02 \\
\hline TCCP x Compost & 6 & 233.688 & 27 & 1.03 & 0.43 \\
\hline \multicolumn{6}{|c|}{ Population (plants ha') } \\
\hline TCCP & 2 & 237554263 & 6 & 4.06 & 0.08 \\
\hline Compost & 3 & 91335947 & 27 & 3.19 & 0.04 \\
\hline TCCP x Compost & 6 & 52209728 & 27 & 1.83 & 0.13 \\
\hline
\end{tabular}


Table 3-16. Tillage/cover crop practice (TCCP) and compost treatment means on yield and growth measurements of 2013 organic soybean.

\begin{tabular}{|c|c|c|c|c|c|c|c|c|}
\hline \multicolumn{2}{|c|}{ Main Effect } & Yield & Leaf $N$ & Grain N & SPAD & Height & Weeds & Population \\
\hline & & $\mathrm{Mg} \mathrm{ha}^{-1}$ & $\overline{-}$ & $\%$ & & $\mathrm{~cm}$ & $\%$ & Plants ha ${ }^{-1}$ \\
\hline \multicolumn{9}{|l|}{ TCCP } \\
\hline NTCC & & 2.15 & 6.1 & 6.9 & 52.2 & 66.2 & 12.4 & 168727 \\
\hline TillCC & & 2.05 & 5.9 & 6.8 & 52.2 & 64.7 & 24.5 & 131591 \\
\hline Till & & 2.24 & 6.0 & 6.7 & 52.4 & 66.7 & 15.6 & 175185 \\
\hline \multicolumn{9}{|l|}{ Compost } \\
\hline 0 & & $2.08 \mathrm{a}$ & 6.1 & 6.8 & 52.2 & 63.4 & $7.3 \mathrm{a}$ & $181375 a$ \\
\hline $0.5 \mathrm{RR}$ & & $1.96 \mathrm{a}$ & 5.9 & 6.8 & 52.4 & 65.0 & $28.3 b$ & $154823 \mathrm{ab}$ \\
\hline $\mathrm{RR}$ & & $2.25 \mathrm{~b}$ & 6.0 & 6.8 & 52.5 & 67.5 & $18.6 \mathrm{ab}$ & $140830 \mathrm{~b}$ \\
\hline $1.5 \mathrm{RR}$ & & $2.29 b$ & 6.1 & 6.7 & 52.1 & 67.6 & $16.0 \mathrm{ab}$ & $156976 a b$ \\
\hline \multicolumn{9}{|c|}{ TCCP x Compost } \\
\hline NTCC & 0 & $1.75 \mathrm{a}$ & 6.0 & 6.8 & 52.2 & $58.7 \mathrm{a}$ & 13.8 & 189448 \\
\hline NTCC & $0.5 \mathrm{RR}$ & $2.02 \mathrm{a}$ & 5.9 & 6.9 & 52.3 & $67.4 \mathrm{~b}$ & 22.5 & 148545 \\
\hline NTCC & $\mathrm{RR}$ & $2.48 \mathrm{~b}$ & 6.3 & 6.8 & 52.5 & $71.8 \mathrm{~b}$ & 8.0 & 172226 \\
\hline NTCC & $1.5 \mathrm{RR}$ & $2.35 b$ & 6.3 & 7.0 & 52.3 & $66.9 \mathrm{~b}$ & 5.5 & 164691 \\
\hline TillCC & 0 & $2.13 \mathrm{ab}$ & 6.0 & 6.8 & 52.6 & $67.1 \mathrm{a}$ & 4.3 & 181375 \\
\hline TillCC & $0.5 \mathrm{RR}$ & $1.88 \mathrm{a}$ & 5.9 & 6.8 & 52.3 & $63.3 \mathrm{a}$ & 35.0 & 129169 \\
\hline TillCC & $\mathrm{RR}$ & $1.93 \mathrm{a}$ & 5.7 & 6.9 & 51.5 & $61.8 \mathrm{a}$ & 31.3 & 90957 \\
\hline TillCC & $1.5 \mathrm{RR}$ & $2.26 \mathrm{~b}$ & 6.0 & 6.6 & 52.2 & $66.6 \mathrm{a}$ & 27.5 & 124864 \\
\hline Till & 0 & $2.37 \mathrm{a}$ & 6.2 & 6.7 & 52.4 & $64.4 \mathrm{a}$ & 4.0 & 173302 \\
\hline Till & $0.5 \mathrm{RR}$ & $1.99 \mathrm{~b}$ & 5.9 & 6.8 & 52.8 & $64.3 \mathrm{a}$ & 27.5 & 186757 \\
\hline Till & $\mathrm{RR}$ & $2.35 \mathrm{a}$ & 6.0 & 6.8 & 52.2 & $68.8 \mathrm{a}$ & 16.5 & 159309 \\
\hline Till & $1.5 \mathrm{RR}$ & $2.26 \mathrm{a}$ & 5.9 & 6.7 & 52.2 & $69.2 \mathrm{a}$ & 15.0 & 181375 \\
\hline
\end{tabular}




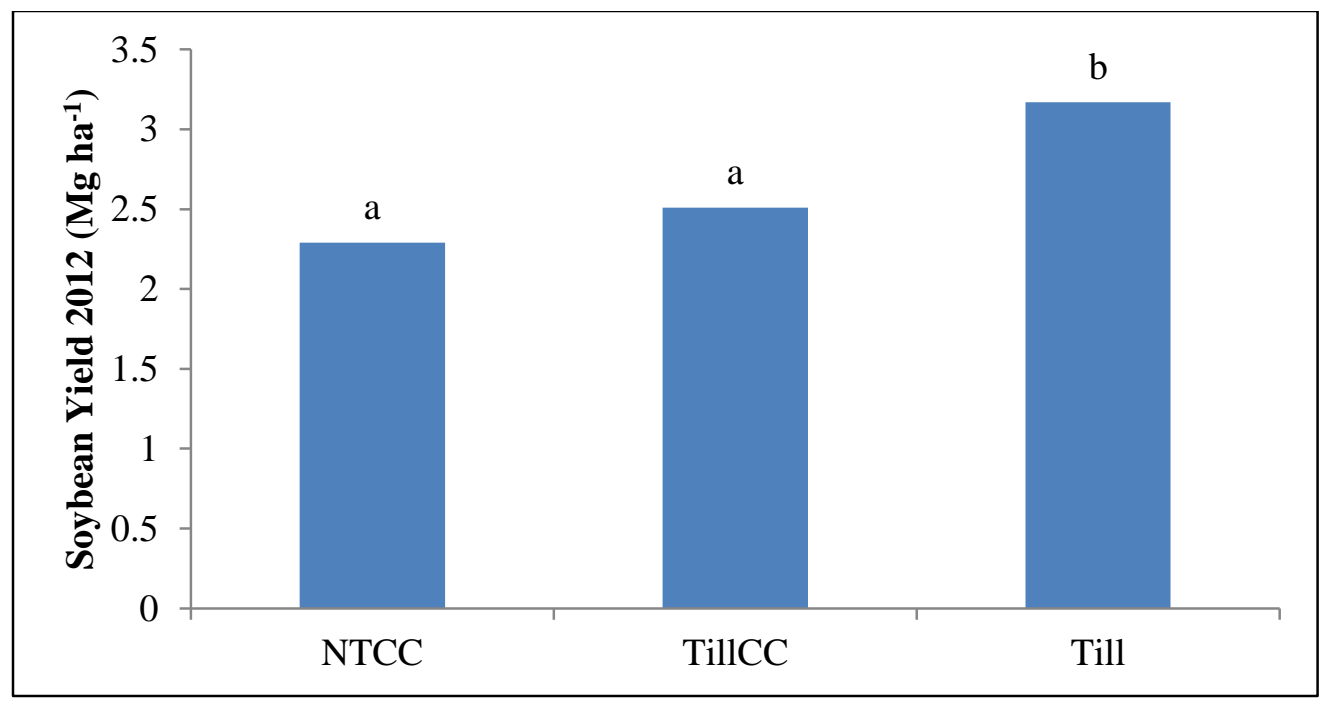

Figure 3-15. Average soybean yield for 2012 according to tillage regime. Means calculated by the least squares mean test when analysis of variance was significant at $\mathrm{P}<0.05$. Different letters indicate statistical differences.

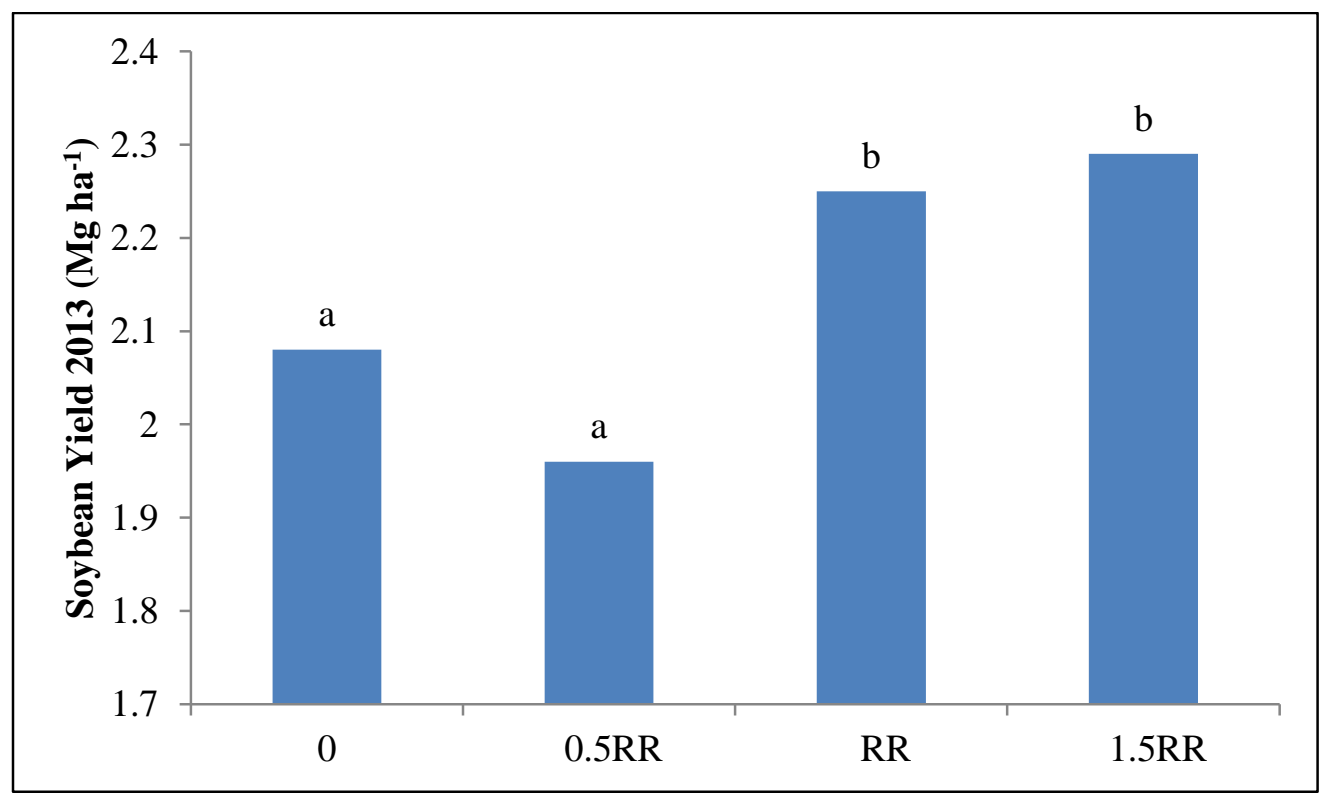

Figure 3-16. Average soybean yield for 2013 according to compost rate. Means calculated by the least squares mean test when analysis of variance was significant at $\mathrm{P}<0.05$. Different letters indicate statistical differences. 


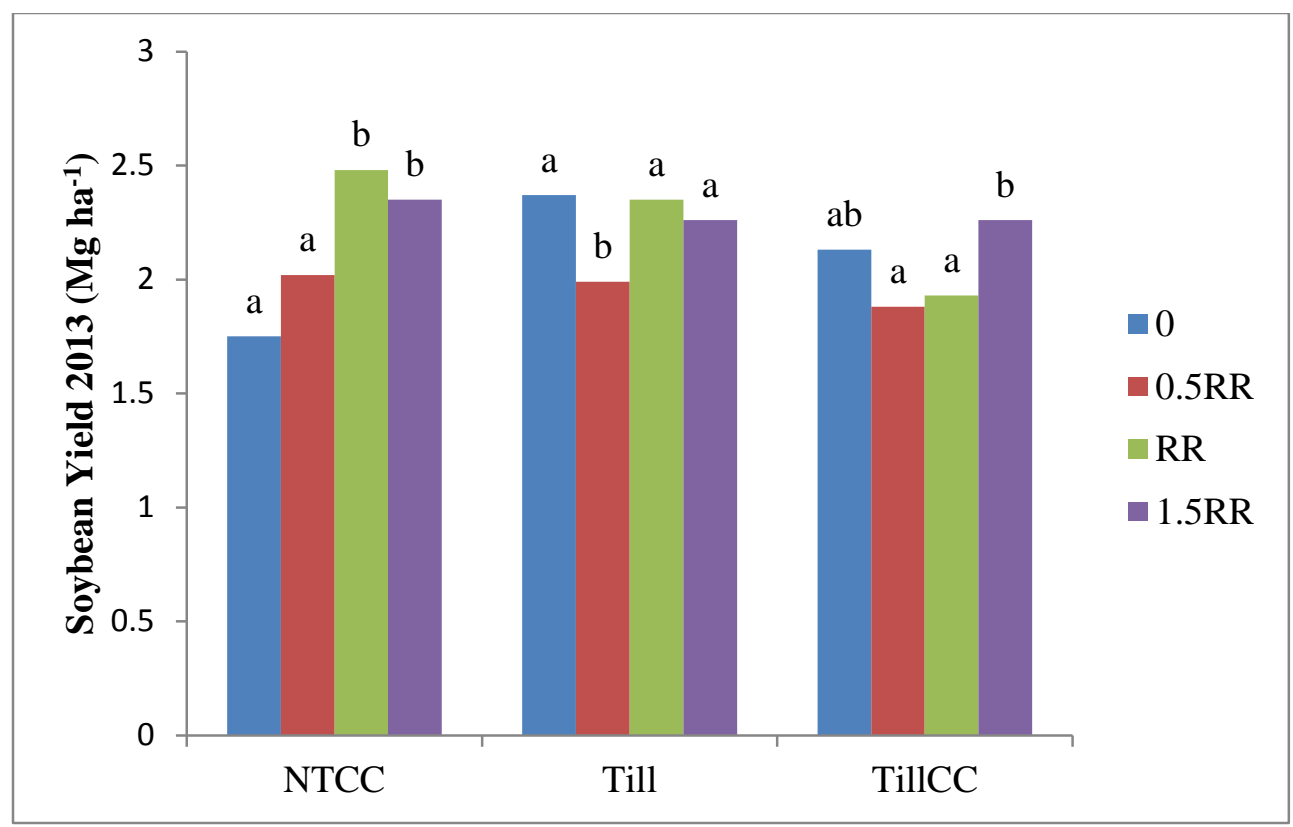

Figure 3-17. Average soybean yield for 2013 according to the interaction of tillage/cover crop practice and compost rate. Means calculated by the least squares mean test when analysis of variance was significant at $\mathrm{P}<0.05$. Different letters indicate statistical differences.

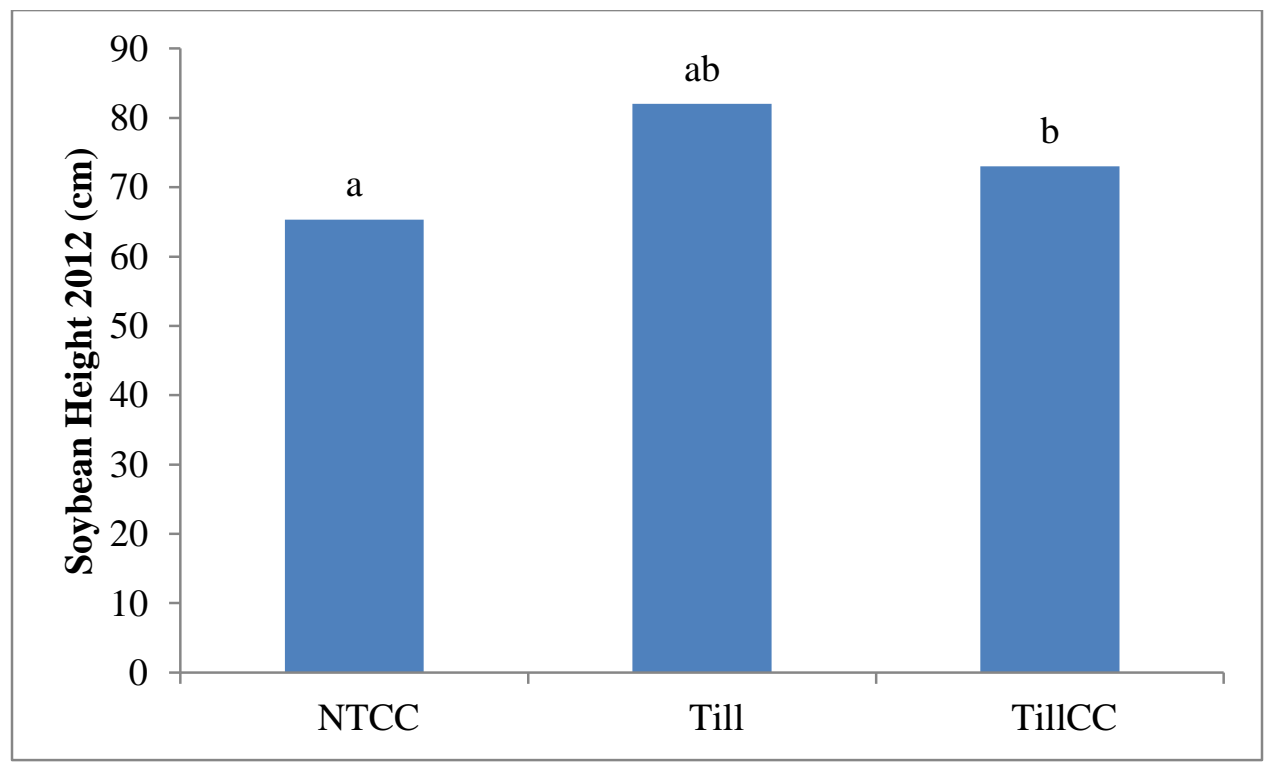

Figure 3-18. Average soybean height for 2012 according to tillage/cover crop practice. Means calculated by the least squares mean test when analysis of variance was significant at $\mathrm{P}<0.05$. Different letters indicate statistical differences. 


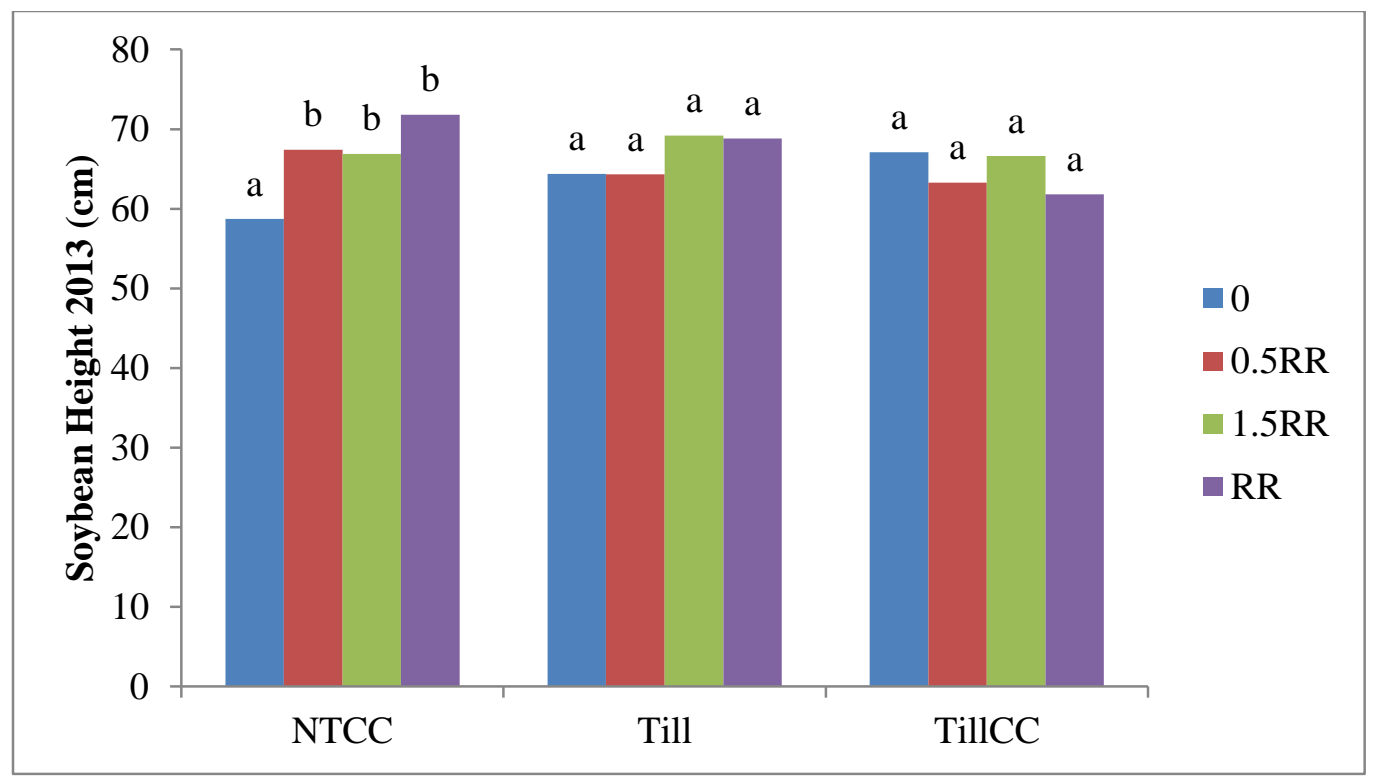

Figure 3-19. Average soybean height for 2013 according to the interaction of tillage/cover crop practice and compost rate. Means calculated by the least squares mean test when analysis of variance was significant at $\mathrm{P}<0.05$. Different letters indicate statistical differences.

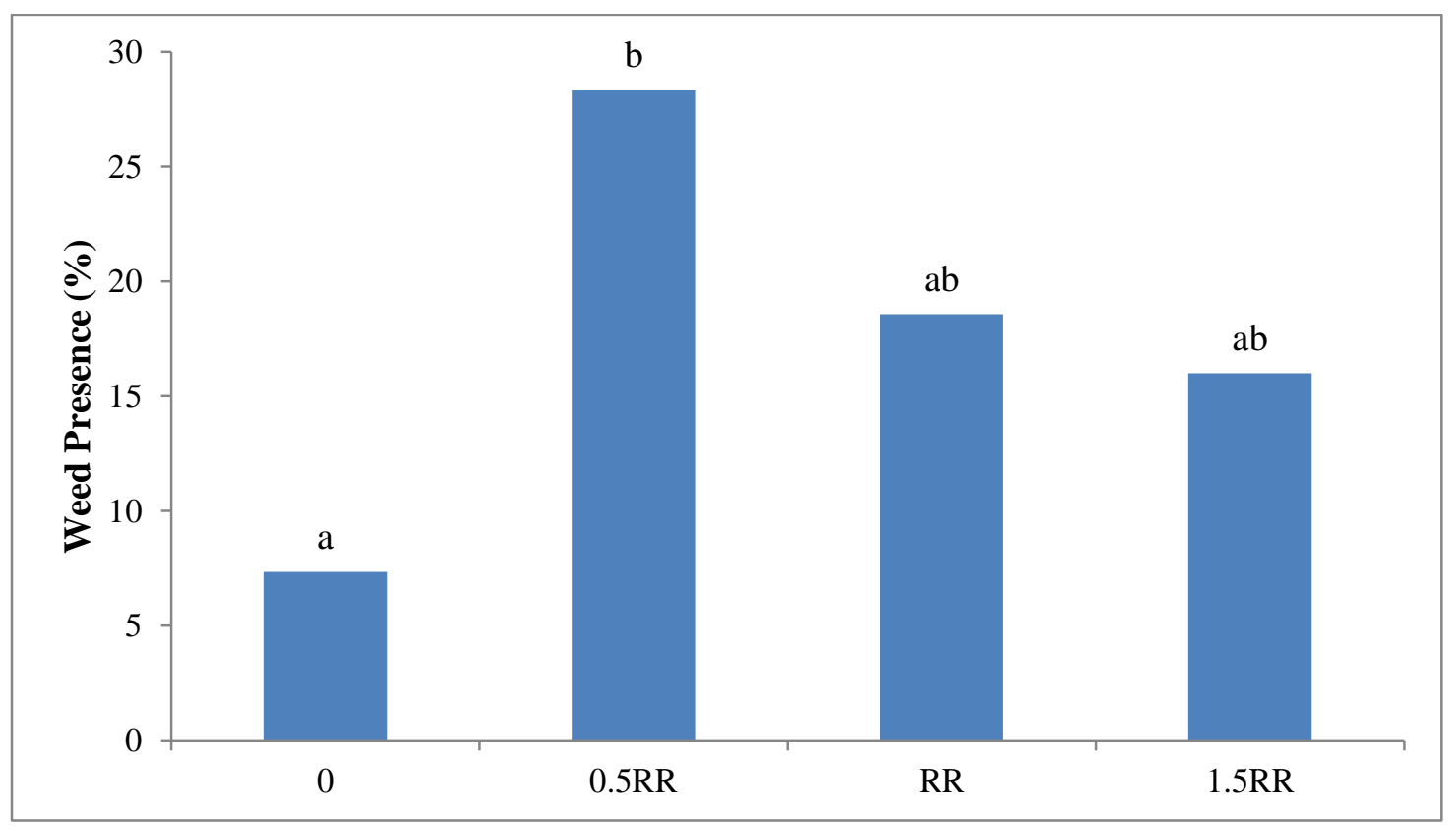

Figure 3-20. Average weed presence as a percentage of total plot area in 2013 according to compost rate. Means calculated by the least squares mean test when analysis of variance was significant at $\mathrm{P}<0.05$. Different letters indicate statistical differences. 


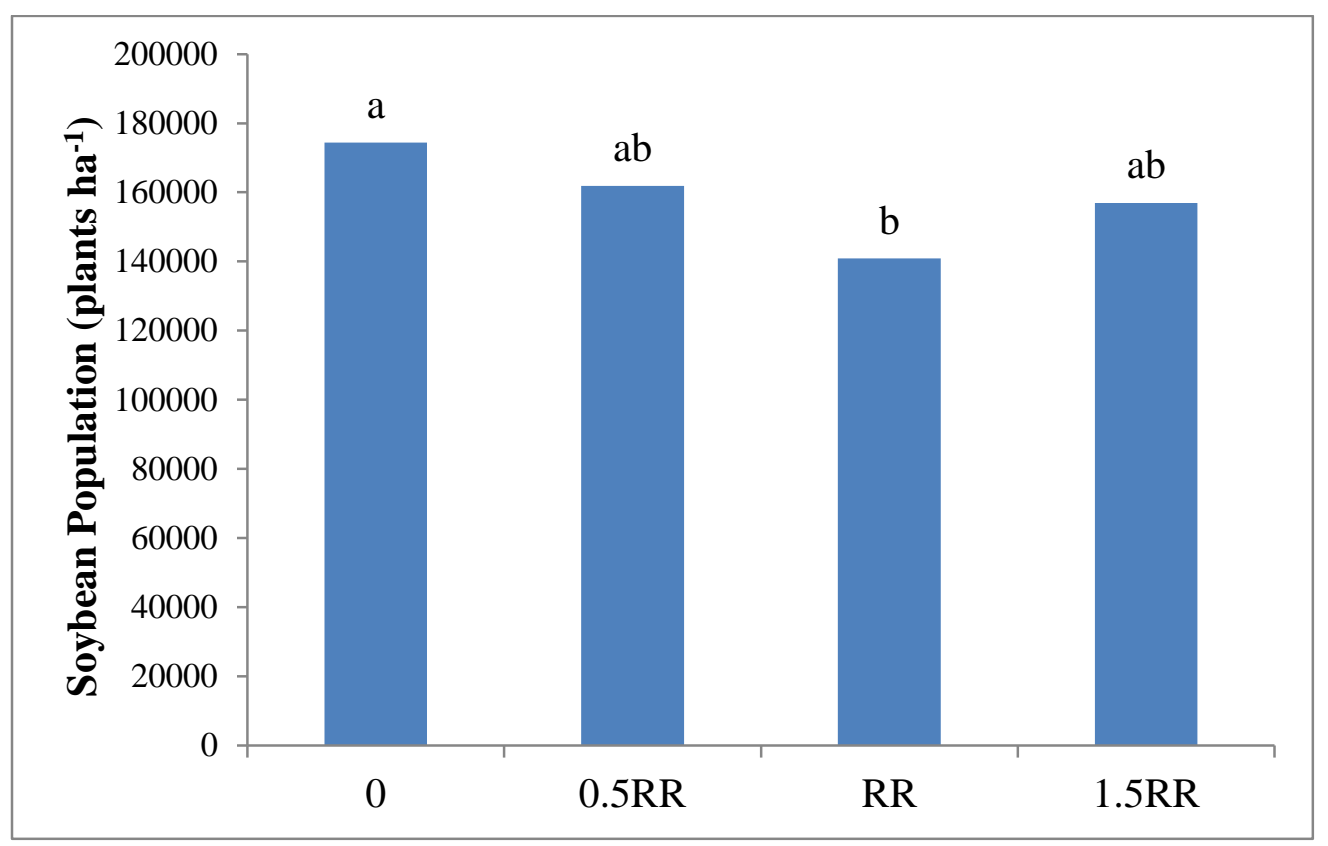

Figure 3-21. Average soybean population at the end of the 2013 growing season according to compost rate. Means calculated by the least squares mean test when analysis of variance was significant at $\mathrm{P}<0.05$. Different letters indicate statistical differences. 


\subsection{REFERENCES}

AMS. 2014. National List of Allowed and Prohibited Substances. USDA. http://www.ams.usda.gov/AMSv1.0/NOPPetitionedSubstancesDatabase

Archer, D. W., Jaradat, A. A., Johnson, J. M., Weyers, S. L., Gesch, R. W., Forcella, F., and Kludze, H. K. 2007. Crop productivity and economics during the transition to alternative cropping systems. Agron. J. 99: 1538-1547.

Baldwin, K. R., and Greenfield, J. T. 2006. Composting on organic farms. Center for Environmental Farming Systems. North Carolina Extension Service, North Carolina. http://www.cefs.ncsu.edu/resources/fieldnotesforfarmers/200506 compost.pdf

Barberi, P. 2002. Weed management in organic agriculture: are we addressing the right issues? Weed Res. 42: 177-193.

Bernstein, E. R., Posner, J. L., Stoltenberg, D. E., and Hedtcke, J. L. 2011. Organically Managed No-Tillage Rye-Soybean Systems: Agronomic, Economic, and Environmental Assessment. Agron. J. 103:1169-1179. doi:10.2134/agronj 2010.0498 .

Blackshaw, R., L. Molnar and F. Larney. 2005. Fertilizer, manure and compost effects on weed growth and competition with winter wheat in western Canada. Crop Protec. 24: 971-980.

Cavigelli, M.A., J.R. Teasdale and A.E. Conklin. 2008. Long-Term Agronomic Performance of Organic and Conventional Field Crops in the Mid-Atlantic Region Agron. J. 100:785-794. doi:10.2134/agronj2006.0373.

Clark, A. 2008. Managing cover crops profitably. 3 ed. Sustainable Agriculture Network. DIANE Publishing, Beltsville, MD.

Cogger, C. G. 2005. Potential compost benefits for restoration of soils disturbed by urban development. Compost Sci. 13:243-251.

Delate, K., D. Cwach and C. Chase. 2012. Organic no-tillage system effects on soybean, corn and irrigated tomato production and economic performance in Iowa, USA. Renew. Agric. Food Sys. 27:49-59.

Eghball, B. 2002. Soil Properties as Influenced by Phosphorus- and Nitrogen-Based Manure and Compost Applications. Agron. J. 94: 128-135. 
Giusquiani, P., M. Pagliai, G. Gigliotti, D. Businelli and A. Benetti. 1995. Urban waste compost: effects on physical, chemical, and biochemical soil properties. J. Envir. Qual. 24: 175-182.

Grandy, A. S., T.D. Loecke, S. Parr, and G. P. Robertson 2006. Long-Term Trends in $\mathrm{N}_{2} \mathrm{O}$ Emissions, Soil Nitrogen, and Crop Yields of Till and No-Till Cropping Systems. J. Envir. Qual. 35:1487-1495

Gupta, S., and Larson, W. 1979. Estimating soil water retention characteristics from particle size distribution, organic matter percent, and bulk density. Water Resour. Res. 15:1633-1635.

Haynes, R., and Naidu, R. 1998. Influence of lime, fertilizer and manure applications on soil organic matter content and soil physical conditions: a review. Nut. Cyc. Agroeco. 51:123-137.

Ingels, C.A. 1998. Cover cropping in vineyards: a grower's handbook.Vol 338. UCANR Publications. University of California. Division of Agriculture and Natural Resources.

Khaleel, R., Reddy, K., and Overcash, M. 1981. Changes in soil physical properties due to organic waste applications. J. Environ.1 Qual. 10:133-141.

Lal, R. 1997. Residue management, conservation tillage and soil restoration for mitigating greenhouse effect by CO2 enrichment. Soil Tillage Res.43: 81-107.

Liebl, R., Simmons, F. W., Wax, L. M., and Stoller, E. W. 1992. Effect of rye (secale cereale) mulch on weed control and soil moisture in soybean (glycine max). Weed Tech. 6: 838-846.

MacKenzie, A. F., Fan, M. X., and Cadrin, F. 1997. Nitrous oxide emission as affected by tillage, corn-soybean-alfalfa rotations and nitrogen fertilization. Can. J. Soil Sci. 77:145-152.

Martens, D., and Frankenberger, W. 1992. Modification of infiltration rates in an organicamended irrigated. Agron. J. 84:707-717.

Menalled, F.D., D.D. Buhler and M. Liebman. 2009. Composted swine Manure Effects on Germination and Early Growth of Crop and Weed Species Under Greenhouse Conditions. Weed Tech. 19(4):784-789.

Myers, D. B., Kitchen, N. R., Sudduth, K. A., Sharp, R. E., and Miles, R. J. 2007. Soybean root distribution related to claypan soil properties and apparent soil electrical conductivity. Crop Sci. 47:1498-1509. 
Nelson, D.W., and L.E. Sommers. 1996. Total carbon, organic carbon, and organic matter. In: D.L. Sparks, editor, Methods of soil analysis. Part 3: Chemical methods. SSSA, Madison, WI. p. 961-1010.

Ouédraogo, E., Mando, A., and Zombré, N. 2001. Use of compost to improve soil properties and crop productivity under low input agricultural system in West Africa. Agric. Ecosys. Envir. 84:259-266.

Place, G. T., Reberg-Horton, S. C., and Burton, M. G. 2009. Effects of preplant and postplant rotary hoe use on weed control, soybean pod position, and soybean yield. Weed Sci. 57:290-295.

Salinas-Garcia, J., Hons, F., and Matocha, J. 1997. Long-term effects of tillage and fertilization on soil organic matter dynamics. Soil Sci. Soc. Am. J. 61:152-159.

Singer, J.W., K.A. Kohler, M. Liebman, T.L. Richard, C.A. Cambardella and D.D. Buhler. 2004. Tillage and Compost Affect Yield of Corn, Soybean, and Wheat and Soil Fertility. Agron. J. 96:531-537. doi:10.2134/agronj2004.5310.

Smith, A.N., S.C. Reberg-Horton, G.T. Place, A.D. Meijer, C. Arellano and J.P. Mueller. 2010. Rolled rye mulch for weed suppression in organic no-tillage soybeans. Weed Science 59:224-231. doi:10.1614/WS-D-10-00112.1.

Smith, R. G., Barbercheck, M. E., Mortensen, D. A., Hyde, J., and Hulting, A. G. 2011. Yield and net returns during the transition to organic feed grain production. Agron. J. 103:51-59.

Stamatiadis, S., M. Werner and M. Buchanan. 1999. Field assessment of soil quality as affected by compost and fertilizer application in a broccoli field. Applied Soil Ecology 12:217-225.

Steiner, C., W.G. Teixeira, J. Lehmann, T. Nehls, J.L.V. de Macêdo, W.E. Blumet al. 2007. Long term effects of manure, charcoal and mineral fertilization on crop production and fertility on a highly weathered Central Amazonian upland soil. Plant Soil 291:275-290.

Takken, I., G. Govers, V. Jetten, J. Nachtergaele, A. Steegen and J. Poesen. 2001. Effects of tillage on runoff and erosion patterns. Soil Tillage Res. 61:55-60. doi:http://dx.doi.org/10.1016/S0167-1987(01)00178-7.

Teasdale, J.R., C.B. Coffman and R.W. Mangum. 2007. Potential long-term benefits of no-tillage and organic cropping systems for grain production and soil improvement. Agron. J. 99:1297-1305. doi:10.2134/agronj2006.0362. 
USDA-ERS 2012. Soybean \& Oil Crops. Economic Research Service USDA. http://www.ers.usda.gov/topics/crops/soybeans-oil-crops.aspx\#.U1Acp1VdXVU

Walz, E. 2004. Final results of the fourth national organic farmers' survey: Sustaining organic farms in a changing organic marketplace. Organic Farming Research Foundation. Santa Cruz, CA. http://ofrf.org/sites/ofrf.org/files/docs/pdf/4 ${ }^{\text {th }}$ survey_results.pdf

Wood, C., Westfall, D., and Peterson, G. 1991. Soil carbon and nitrogen changes on initiation of no-till cropping systems. Soil Sci. Soc. Am. J. 55: 470-476.

Yenish, J.P., A.D. Worsham and W.S. Chilton. 1995. Disappearance of DIBOAglucoside, DIBOA, and BOA from rye (Secale cereale L.) cover crop residue. Weed Science 57:18-20.

Yussefi, M. and H. Willer. 2007. Organic farming worldwide 2007: overview \& main statistics. The World of Organic Agriculture-Statistics and Emerging Trends 2007: 9-16. http://www.env-edu.gr/Documents/The\%20world\%20of\%20organic $\% 20$ agriculture.pdf 


\section{VITA}

Steven Easterby was born on November 22, 1986 to David and Sean Easterby in Glendale, CA. He was raised between southern California and Omaha, NE and graduated from Creighton Preparatory High School in 2005. Steven attended Colorado State University to receive his Bachelor's of Science in Natural Resources Recreation and Tourism degree with an emphasis in Environmental Communications. He served for two years as a Peace Corps Volunteer on the island of São Nicolau in the country of Cape Verde. Steven began his Master's of Science in Soil, Environmental, and Atmospheric Science at the University of Missouri under the advisement of Dr. Newell Kitchen in 2012. He graduated with his Master's degree in May 2014. Steven then began working for Agrimanagement, an agronomy consulting business in Yakima, WA. 